



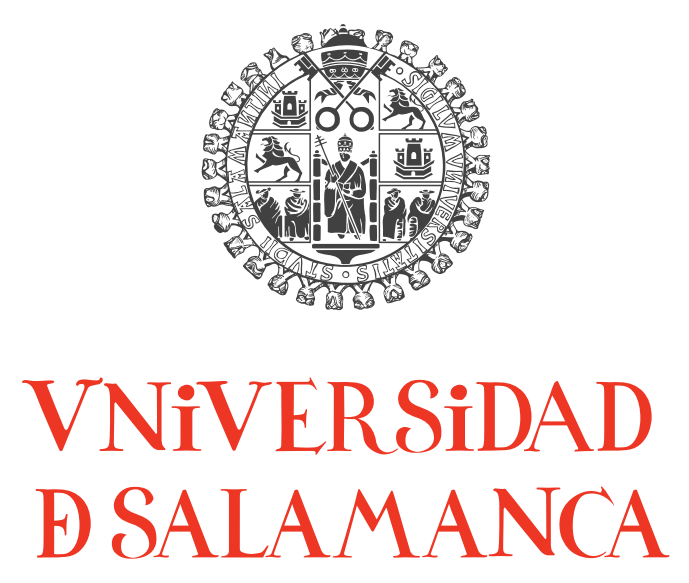

\title{
Estudio epigenético del asma alérgica mediante el análisis de patrones de metilación
}

\author{
Unidad de Alergia e Inmunología Clínica \\ Departamento de Pediatría, Obstetricia y Ginecología
}

Hospital Universitario de Salamanca 
Unidad de Alergia e Inmunología Clínica

Departamento de Pediatría, Obstetricia y Ginecología

Hospital Universitario de Salamanca

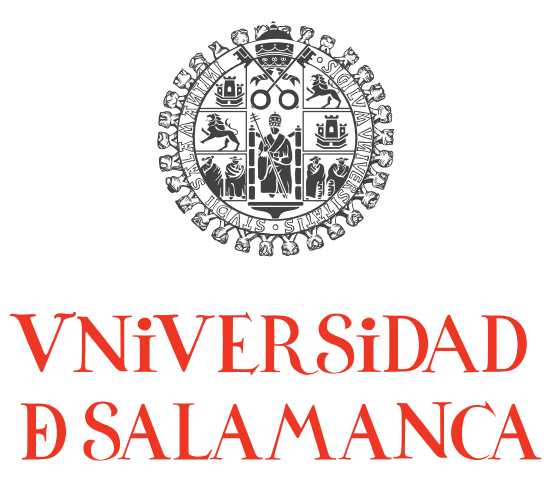

\section{Estudio epigenético del asma alérgica mediante el análisis de patrones de Metilación.}

Marién Pascual de Pedro para optar al

Grado de Doctora

Directores

Dr. Félix Lorente Toledano

Dr Ignacio Dávila González

Dra. María Isidoro García 
EL Dr. D. FELIX LORENTE TOLEDANO, CATEDRÁTICO DEL DEPARTAMENTO DE OBSTETRICIA, GINECOLOGÍA Y PEDIATRÍA, EL Dr. D. IGNACIO DÁVILA GONZÁLEZ, PROFESOR ASOCIADO DE ALERGOLOGÍA DEL DEPARTAMENTO DE OBSTETRICIA, GINECOLOGÍA Y PEDIATRÍA Y LA Dra. Dña MARIA ISIDORO GARCÍA, PROFESORA ASOCIADA DEL DEPARTAMENTO DE MEDICINA MOLECULAR

\section{CERTIFICAN:}

Que el trabajo titulado "Estudio epigenético del asma alérgica mediante el análisis de patrones de metilación”, que presenta la Licenciada en Bioquímica Doña Marién Pascual de Pedro, ha sido realizado bajo nuestra dirección, en la Unidad de Alergia e Inmunología Clínica del Departamento de Pediatría, Obstetricia y Ginecología de la Universidad de Salamanca, y reúne, a nuestro juicio, originalidad y contenidos suficientes para que sea presentado ante el tribunal correspondiente y pueda optar al título de "Doctora de la Universidad de Salamanca".

Y para que así conste, y a los efectos oportunos, expedimos el presente certificado en Salamanca, a 2 de Junio de 2010.

\section{Prof. Dr. Félix Lorente}

Prof. Dr. Ignacio Dávila 

Life isn't worth living, unless it is lived for someone else.

Advent bis stein 



\section{Agradecimientos}

Al Dr. Félix Lorente Toledano, al Dr. Ignacio Dávila y a la Dra. María Isidoro García, GRACIAS. Gracias por Todo y por Tanto. Gracias por la inmensa confianza depositada, por el entusiasmo regalado y siempre contagioso, por todo el apoyo que me habéis brindado durante este tiempo. Gracias por los correos, las llamadas de teléfono, los mensajes de esperanza, los "yo sé que tú ahora no lo ves, pero yo lo tengo tan claro...". Gracias porque, a pesar de que nuestra hipótesis de trabajo era novedosa y arriesgada, me permitlsteis apostar por ella, avalándome en cada momento, sin pedir nada a cambio.

Mis compañeros de laboratorio y de la Unidad de Alergia e Inmunología Clínica en Salamanca han sido un regalo inesperado. Muchísimas gracias a todos. No importa cuánto tiempo pase, Juana, Virginia, Arturo, David, Eva, Laura y Cati siempre me han recibido con una gran sonrisa, ayudándome de forma desinteresada. Gracias, Juana, por todos los papeleos de los que te has preocupado, ¿qué haría yo sin ti? Hay muchas personas que me han aportado mucho por muy poco: Carmen, Juan, Esther...

I am deeply grateful to Dr. John M. Greally and his lab. When I remember the first time Dr. Greally interviewed me, a big smile comes. It was a huge decision in my life and I was extremely nervous. Thanks for giving me this huge opportunity, for all the patience while I was learning and the great support. Thanks to my former lab mates (Dr. Khulan, Dr. Oda, Dr. Tewari, Dr. Glass and Dr. Thompson), with whom I have at 
least one funny story between us. My lab mates are now more than coworkers, I have found a small japanese-jewish-chiliean-polish-indian-american-greek family. Thanks Masako, because you have been always a great mentor and a better friend. Maria Paz: ¡GRACIAS! por tu entusiasmo, por la vida que desprendes. Edyta: Is there anything better than a Greally Lab girl?? Niki and Esther thanks for all your advice and good friendship. Niru and Andrew.... am not the crazy one....Thanks for letting me be your teacher, my summer students...

Gracias a todos los que desde niña habéis creído en mí, especialmente en los momentos (que han sido quizá demasiados) en los que yo no lo hacía. Gracias por ese calor de hogar que siento cuando estoy con mi Familia. A mis padres, Esteban y Marién, por su ejemplo de vida, por su entusiasmo por ella. Porque ya saben sólo por mi forma de decir "hola", cómo estoy o qué me pasa. Gracias por todos los consejos, por todos los sacrificios que habéis hecho para que yo llegara hasta aquí. A mis hermanos, Jorge y Esteban, que van creciendo, luchando por sus sueños, se están convirtiendo en hombres buenos, de los que una hermana se puede sentir orgullosa.

Esta experiencia me ha ayudado a admirar, más si cabe, a mis Abuelos. Pertenecen a una generación española de inmigrantes, que por motivos económicos tuvo que salir de España. Dejaron atrás todo lo que querían, sus mujeres, sus hijos, con el único objetivo de poder proporcionarles un futuro mejor. El camino 'fácil' que he tenido yo no se puede comparar con el pedregoso que tuvieron ellos. Gracias, porque aunque no lo sepáis, con vuestro ejemplo de superación, habéis sido un punto de soporte y referencia muy importante durante este tiempo. María, Teodora, mis Abuelas. Lo que he aprendido de vosotras no está en ningún libro de 
texto, y tiene la ventaja de que nunca se me olvidará. Gracias porque sé que sin vosotras, Yo, Nosotros, no seríamos lo que hoy somos.

Gracias, Sergio. Porque no sólo este trabajo tiene tu huella, sino mi vida que ya está marcada por vivirla contigo. Compañero infatigable de camino, siempre armado con una sonrisa y un saco de paciencia para escucharme y ayudarme. Gracias porque sin ti, yo no sería.

Por último, pero no menos importante, gracias por esa Amistad que no tiene precio y que no podré pagar nunca. Gracias por no olvidaros, a pesar de que nunca estuviera. Habéis sido muchos: Sara, Diana, mis amigas del Impacto, mis amigos del coro, mis amigos de Miranda, mis amigos de Salamanca... Gracias por cada correo de esos que despiertan sonrisas y que me hacían recordar cuánto os echaba de menos. Gracias, "Spanish Community”, por traer aires españoles al Bronx.

Gracias a todos los que sabéis que este trabajo se ha llevado sangre, sudor y lágrimas. 



\section{Tabla de contenidos}

1 INTRODUCCIÓN 17

$\begin{array}{lll}1.1 & \text { SISTEMA INMUNE } & 18\end{array}$

$\begin{array}{lll}1.1 .1 & \text { INTRODUCCIÓN } & 18\end{array}$

$\begin{array}{ll}1.1 .2 & \text { ASMA Y ALERGIA } \\ 1.1 .3 & 19\end{array}$

$\begin{array}{lll}1.1 .3 & \text { FENOTIPOS DE ASMA } & 20\end{array}$

1.1.4 LA REACCIÓN ALÉRGICA

1.1.5 BASES INMUNOLÓGICAS DE LAS REACCIONES ALÉRGICAS 25

1.1.6 CARACTERÍSTICAS DE LA REACCIÓN ALÉRGICA 31

$\begin{array}{lll}\text { 1.1.7 AlERGIA A lOS ACAROS DEL POLVO } & 38\end{array}$

1.1.8 PREVALENCIA DE LAS ENFERMEDADES ALÉRGICAS 39

$\begin{array}{lll}1.2 & \text { EPIGENÉTICA } & 43\end{array}$

$\begin{array}{lll}1.2 .1 & \text { INTRODUCCIÓN } & 43\end{array}$

$\begin{array}{lll}1.2 .2 & \text { HISTONAS } & 44\end{array}$

1.2.3 METILACIÓN DEL DNA

1.2.4 Fisiología DE LA METILACIÓN DEL DNA 49

1.2.5 ESTRATEGIAS PARA EL ESTUDIO DEL EPIGENOMA

1.3 EPIGENÉTICA, MEDIO AMBIENTE Y ENFERMEDAdES AlÉRgICAS 66

1.3.1 HIPÓTESIS DE LA HIGIENE

1.3.2 ORÍGENES DE LA SALUD Y LA ENFERMEDAD DURANTE EL DESARROLlO (DEVELOPMENTAL $\begin{array}{ll}\text { ORIGINS OF HEALTH AND DISEASE) } & 67\end{array}$

1.3.3 EPIGENÉTICA Y REGULACIÓN DE LA RESPUESTA INMUNE

1.3.4 ALERGIA, EPIGENETICA Y FACTORES AMBIENTALES 70

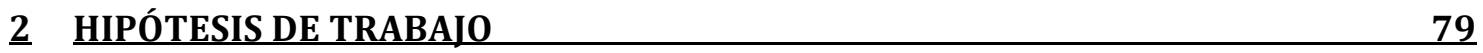

\begin{tabular}{ll}
$\underline{3}$ OBJETIVOS & 81 \\
\hline
\end{tabular}

4 MATERIAL Y MÉTODOS $\quad 83$

$\begin{array}{lll}4.1 & \text { SELECCIÓN DE LA POBLACIÓN DE ESTUDIO } & 84\end{array}$

4.1.1 DIAGNÓSTICO DE ASMA $\quad 84$

4.1.2 DiAgNóSTICO DE ALERGIA

4.1.3 DETERMINACIÓN DE IGE

$\begin{array}{lll}4.1 .4 & \text { CONTROLES } & 88\end{array}$

$\begin{array}{lll}4.1 .5 & \text { PACIENTES } & 88\end{array}$

$\begin{array}{lll}4.2 & \text { ANÁLISIS MOLECULAR } & 89\end{array}$

4.2.1 OBTENCIÓN DE LINFOCITOS MEDIANTE GRADIENTE DE DENSIDAD 89

4.2.2 OBTENCIÓN DE CÉLULAS CD19 MEDIANTE SELECCIÓN INMUNOMAGNÉTICA 90

4.2.3 CiTOMETRÍA DE FLUJO 91 
4.2.4 ENVÍO DE LAS MUESTRAS $\quad 91$

4.2.5 PURIFICACIÓN DEL DNA 92

4.2.6 PURIFICACIÓN DEL RNA $\quad 95$

4.2.7 CUANTIFICACIÓN DE ÁCIDOS NUCLEICOS 97

4.2.8 OBTENCIÓN DE DSCDNA A PARTIR DEL RNA 97

4.2.9 AMPLIFICACIÓN DEL RNA 99

$\begin{array}{lll}4.2 .10 & \text { PCR CUANTITATIVA (Q-PCR) } & 100\end{array}$

$\begin{array}{lll}4.2 .11 & \text { HELP ASSAY } & 104\end{array}$

4.2.12 HIBRIDACIÓN EN MICROARRAYS 111

4.2.13 ANÁLISIS DE LOS DATOS $\quad 114$

4.2.14 TRATAMIENTO CON BISULFITO SÓDICO $\quad 117$

$\begin{array}{lll}4.2 .15 & \text { ESPECTROMETRÍA DE MASAS } & 120\end{array}$

4.2.16 DISEÑO DE LOS OLIGOS Y REACCIÓN EN CADENA DE LA POLIMERASA (PCR) 122

$\begin{array}{lll}\text { 4.2.17 VALIDACIÓN DE LOS MICROARRAYS } & 123\end{array}$

$\underline{5}$ RESULTADOS $\quad 125$

5.1 Características de La POBLACIÓN

5.2 AISLAMIENTO DE CÉlULAS B $\quad 126$

5.3 ESTUDIO GLOBAL DE LOS PATRONES DE METILACIÓN DE LINFOCITOS B 127

$\begin{array}{lll}\text { 5.3.1 HELP ASSAY } & 127\end{array}$

5.3.2 NORMALIZACIÓN DE CUANTILES 131

$\begin{array}{ll}\text { 5.3.3 GRÁFICO DE DENSIDADES } & 132\end{array}$

$\begin{array}{lll}\text { 5.3.4 DENDOGRAMAS } & 135\end{array}$

$\begin{array}{lll}\text { 5.3.5 VISUALIZACIÓN DE LOS DATOS } & 136\end{array}$

$\begin{array}{lll}5.3 .6 & \text { HEATMAP } & 137\end{array}$

$\begin{array}{lll}5.3 .7 & \text { VOLCANO } & 138\end{array}$

$\begin{array}{lll}\text { 5.3.8 } & \text { P-VALUES PLOT } & 140\end{array}$

$\begin{array}{ll}\text { 5.3.9 INGENUITY PATHWAY ANALYSIS } & 140\end{array}$

$\begin{array}{llr}\mathbf{5} .4 & \text { ESTUDIO DE METILACIÓN A NIVEL LOCAL } & \mathbf{1 4 4}\end{array}$

5.4.1 VALIDACIÓN DE LOS DATOS MEDIANTE MASSARRAY 144

$\begin{array}{llr}5.5 & \text { EXPRESIÓN } & 149\end{array}$

6 DISCUSIÓN 150

6.1 LA VITAMINA A EN EL SISTEMA INMUNE 162

6.1.1 REGULACIÓN DE LA EXPRESIÓN CELULAR 165

6.1.2 METABOLISMO DEL ÁCIDO RETINOICO: CYP26A1 166

$\begin{array}{lll}6.2 & \text { CONSIDERACIONES FINALES } & 168\end{array}$

7 CONCLUSIONES $\quad 171$

$\underline{8}$ INDICE DE FIGURAS $\quad 176$ 
9 INDICE DE TABLAS

10 ABREVIATURAS $\quad 180$

11 REFERENCIAS BIBLIOGRÁFICAS 183 

1 Introducción 


\subsubsection{Introducción}

Los organismos multicelulares han desarrollado mecanismos de protección contra los agentes patógenos, constituyendo una primera línea de protección conocida como inmunidad innata. La inmunidad innata está mediada por mecanismos tanto celulares como humorales y se caracteriza, en líneas generales, por su inespecificidad y ausencia de memoria a pesar de que el antígeno haya sido previamente presentado, si bien la inmunidad innata es mucho más compleja que lo que inicialmente se pensaba.

Además, los vertebrados disponen de un sistema de protección adicional caracterizado por una respuesta específica a determinados antígenos, que emplea receptores específicos, generados mediante un proceso de recombinación somática de determinados segmentos genéticos, conocidos como anticuerpos. Aparte de proveer un repertorio enorme de respuestas antígeno-anticuerpo específicas, esta respuesta presenta memoria inmunológica, por lo que posteriores reencuentros con un antígeno conocido conllevan una rápida respuesta inmunológica. Estos procesos se engloban dentro de la inmunidad adquirida y las principales células efectoras son los linfocitos.

Los linfocitos se incluyen dentro de la línea de células blancas de la sangre y comprenden linfocitos B, T y linfocitos citolíticos espontáneos (Natural Killer, NK). Se originan en la médula ósea a partir de un progenitor linfoide común, denominado LMP (de sus siglas en inglés Lymphoid Mieliod Progenitor). Los linfocitos B y T son los efectores de la respuesta inmune adaptativa, mientras que 
los NK no presentan recombinación de receptores antigénicos y se consideran parte de la respuesta inmune innata.

Los seres humanos, ratones y otras especies de vertebrados son capaces de generar un gran repertorio de anticuerpos con el fin de protegerse de agentes infecciosos o sustancias tóxicas en el ambiente, en lo que se conoce como respuesta inmune humoral.

\subsubsection{Asma y Alergia}

En las enfermedades alérgicas, los términos "compleja" o "multifactorial" se usan de forma indistinta para describir enfermedades que no son el resultado obvio de una sola mutación o de influencias ambientales. La carga genética de estas enfermedades es indudable, y numerosos estudios han demostrado tanto su heredabilidad como la influencia de determinados factores ambientales, pero ambos han demostrado no ser suficientes a la hora de entender la prevalencia de las mismas (1).

La rinitis alérgica, la dermatitis atópica, el asma alérgica, la alergia alimentaria o la anafilaxia son enfermedades con base alérgica que se caracterizan por presentar niveles elevados de IgE específica para uno o varios alérgenos, desencadenantes de la reacción inflamatoria. En otros tipos de alergia, como la dermatitis por contacto se piensa que la IgE no desempeña un papel tan importante (2). La sensibilización frente a un antígeno pone en evidencia la habilidad de éste para desencadenar una respuesta $\mathrm{Th} 2$, en la que se produce un aumento de interleucinas como la IL-4 y la IL-13, que promueven el cambio de isotipo de inmunoglobulinas en los linfocitos B (3). 


\subsubsection{Fenotipos de Asma}

El primer problema al que se enfrentan los estudios epidemiológicos sobre el asma es el de su definición, que combina la historia clínica y la exploración física. En la Estrategia Global para el Asma (GINA) la enfermedad se define como "una inflamación crónica de las vías respiratorias asociada a hiperreactividad bronquial, que cursa con episodios recurrentes de sibilancias, disnea, opresión torácica y tos, particularmente durante la noche o la madrugada, y que se asocia con un trastorno ventilatorio obstructivo reversible, de forma espontánea o con tratamiento" (4).

Esta enfermedad se encuentra en ambos sexos y en todos los grupos étnicos, presentando diferencias tanto en síntomas como en gravedad (5). Se ha propuesto considerar al asma más que como una única enfermedad, como un conjunto de síndromes solapados. Las características clínicas y las exploraciones complementarias de la enfermedad nos permiten diferenciar dos tipos de asma, atópica y no atópica. Aparte de ser anatomopatológicamente indistinguibles, ambos tipos de asma se caracterizan por una obstrucción reversible del flujo aéreo, aparición de sibilancias con el esfuerzo, variación diurna del tono bronquial y eosinofilia en el esputo y en sangre periférica (6).

La respuesta inflamatoria en el asma atópica se asocia a una sensibilización frente a determinados alérgenos y, en la mayor parte de las ocasiones, a una elevación de la IgE sérica total. Las citocinas derivadas de las células Th2 dirigen la respuesta asmática a través de su efecto sobre otras células (linfocitos $\mathrm{B}$, 
mastocitos, eosinófilos) o por interacción directa con células estructurales del pulmón.

Esta respuesta se asocia principalmente con la secreción de las interleucinas (IL) IL-4, IL-5 e IL-13, que tiene como consecuencia la activación de moléculas de adhesión y producción de otras citocinas y quimiocinas, que desencadenarán un proceso de reclutamiento celular y posterior desgranulación de los eosinófilos, mastocitos y basófilos, junto con la activación de los linfocitos B y la consiguiente producción de IgE (7).

Muchos pacientes que inicialmente sólo presentan un tipo de enfermedad alérgica, como una dermatitis atópica, acaban desarrollando otras, como rinitis alérgica, asma alérgica, o alergia alimentaria, proceso que es conocido como marcha atópica (8). Rhodes y colaboradores (9) llevaron a cabo un estudio en el Reino Unido en el que evaluaron la evolución de 100 bebés, considerados de riesgo, ya que al menos uno de los padres debía ser atópico. El estudio, que comenzó en 1976, se prolongó durante 22 años. La prevalencia de dermatitis atópica fue del $20 \%$ tras el primer año, descendiendo al 5\% al final del estudio. Mientras tanto, la prevalencia de la rinitis alérgica fue aumentando en el tiempo, del 3 al 15\% y la dificultad respiratoria descrita ascendió del 5\% al 40\% al final del estudio. La sensibilización alérgica a una batería de alérgenos comunes afectó al 36 \% de los participantes.

Esta secuencia típica de manifestaciones clínicas, caracterizada por el desarrollo de dermatitis atópica a una edad temprana y posterior desarrollo de otras enfermedades desarrolladas se ha observado en numerosos estudios $(10,11)$. 
El asma no atópica se caracteriza porque no se puede demostrar la presencia de IgE específica para un determinado antígeno en sangre periférica, piel o mucosa bronquial. Los niveles de IgE séricos suelen encontrarse dentro de los valores normales. Además, suele iniciarse a edades medias de la vida, es rara la remisión y, en general, suele ser más grave, existiendo una mayor incidencia de hipersensibilidad a los fármacos antiinflamatorios no esteroideos (AINE)(6).

En la patogenia del asma no atópica los eosinófilos también pueden desempeñar un papel importante como células proinflamatorias, ya que contribuyen a la reacción broncoconstrictora mediante la liberación de leucotrienos, metabolitos de oxígeno y proteínas tóxicas, entre otros factores.

\subsubsection{La Reacción Alérgica}

El término "alergia" fue utilizado por primera vez por Clemens von Pirquet en 1906 para definir la inusual tendencia de algunas personas a desarrollar signos y síntomas de reactividad, o "reacciones de hipersensibilidad" cuando se exponían a determinadas sustancias aparentemente inocuas (12). Las enfermedades atópicas, (del Griego atopos, fuera de lugar) se asocian con la producción de IgE específica y con la expansión de poblaciones de células T específicas, que son reactivas frente a lo que en condiciones normales son sustancias no nocivas.

Las reacciones de hipersensibilidad pueden ser divididas en cuatro grupos, según la clasificación clásica propuesta por Coombs y Gell (Tabla 1). A pesar de que esta clasificación es útil en términos didácticos, en la práctica clínica es difícil de aplicar ya que tanto las respuestas celulares como las humorales ocurren al mismo y tiempo de forma solapada (7). 
Tabla 1. Clasificación de las reacciones de hipersensibilidad propuesta por Coombs y Gell

\begin{tabular}{|c|c|c|c|}
\hline \multicolumn{2}{|c|}{ Hipersensibilidad mediada por Anticuerpos } & $\begin{array}{c}\text { Hipersensibilidad } \\
\text { celular }\end{array}$ \\
\hline Tipo I & Tipo II & Tipo III & Tipo IV \\
\hline Mediada por IgE & $\begin{array}{c}\text { Respuesta humoral } \\
\text { citotóxica }\end{array}$ & $\begin{array}{c}\text { Respuesta inmunitaria } \\
\text { mediada por complejos } \\
\text { inmunes }\end{array}$ & Mediada por células T \\
\hline $\begin{array}{c}\text { Rinitis alérgica } \\
\text { Asma bronquial }\end{array}$ & Citopenia por fármacos & $\begin{array}{c}\text { Vasculitis } \\
\text { Alveolitis alérgica }\end{array}$ & $\begin{array}{c}\text { Alergia de contacto } \\
\text { Exantemas }\end{array}$ \\
\hline
\end{tabular}

En el sentido estricto del término, las reacciones anafilácticas, de tipo I o inmediatas son aquellas que se refieren a una respuesta mediada por la IgE (13). Estas reacciones se desarrollan entre segundos y minutos tras el contacto con el alérgeno, debido a la liberación de mediadores preformados en mastocitos y basófilos.

La mayoría de los alérgenos capaces de desencadenar esta respuesta son de masa molecular que oscila entre 6 y 120 kilodalton (kDa) (14) y altamente hidrófilos, capaces de penetrar en el cuerpo humano a través de las mucosas del tracto respiratorio y digestivo (7). En las personas sensibilizadas, cantidades mínimas de alérgeno son capaces de desencadenar una respuesta alérgica.

Las reacciones de tipo II o citotóxicas están mediadas por anticuerpos de tipo IgG o IgM, capaces de reconocer antígenos presentes en la superficie celular. Esta reacción conlleva la formación de complejos inmunes y la interacción de éstos con el sistema del complemento y con receptores de Fc-IgG presentes en los macrófagos y en las células NK, entre otras. Las células afectadas son eliminadas en cuestión de minutos. Entre las enfermedades asociadas con respuestas de 
hipersensibilidad de tipo II por activación del complemento están las citopenias inducidas por fármacos.

Las reacciones de tipo III se conocen también como mediadas por inmunocomplejos. Estas reacciones se presentan al formarse complejos antígenoanticuerpo insolubles en el torrente circulatorio. A pesar de ser en sí mismo un proceso fisiológico, en el caso de que estos complejos no sean eliminados adecuadamente mediante fagocitosis en el bazo o en otro órgano linfático, pueden depositarse en las paredes del sistema circulatorio, en la piel o en las articulaciones, lo que conllevará la activación del sistema del complemento y el reclutamiento de otras células inmunes.

En la fisiopatología de las reacciones de hipersensibilidad de tipo IV o retardadas son los linfocitos $\mathrm{T}$, sin la mediación de anticuerpos, los que reaccionan de forma inapropiada contra antígenos propios o contra antígenos extraños asociados a tejidos o células. Este tipo de reacciones ha sido más tarde subdividida, a medida que se ha ido incrementado el conocimiento sobre los linfocitos T, en cuatro subtipos (15).

Las reacciones de hipersensibilidad de tipo IVa están mediadas por linfocitos T Th1, que activan a los macrófagos mediante la secreción de INF- $\gamma$ (probablemente otras citocinas como el TNF $\alpha$ o la IL-18), promoviendo la producción de anticuerpos relacionados con el sistema del complemento (IgG1, IgG3), o actuando como estimuladores de la respuesta inflamatoria y estimulando la activación de respuestas $\mathrm{T} \mathrm{CD}^{+}(16)$. 
Se incluyen dentro de las reacciones de tipo IVb las mediadas por células Th2, secretoras de las IL-4, IL-5 e IL-13. Estas citocinas activarán la producción de IgE e IgG4 por parte de los linfocitos $\mathrm{B}$, así como la activación de los eosinófilos y mastocitos (16). Los elevados niveles de IL-5 secretados promueven una reacción inflamatoria eosinofílica, característica de numerosas reacciones adversas a medicamentos (17).

En las reacciones de hipersensibilidad IVC son las propias células T CD8+ citotóxicas las que actúan como efectoras, secretando proteínas citolíticas (perforina) o serín proteasas (granzima B), con la consiguiente inducción a la apoptosis de las células afectadas (18). En general, las reacciones de hipersensibilidad mediadas por linfocitos T CD8+ citotóxicos se consideran más peligrosas, ya que todas las células que expresan MHC-I (Complejo Principal de Histocompatibilidad I) pueden ser posibles dianas, mientras que aquellas en las que participan linfocitos $C D 4^{+}$, están dirigidas exclusivamente a aquellas células que expresan MHC-II (Complejo Principal de Histocompatibilidad II).

Por último, las reacciones de tipo IVd se caracterizan por la coordinación mediada por células $\mathrm{T}$ de una inflamación neutrofílica. Los principales mediadores de esta reacción son CXCL-8 y GM-CSF (16).

\subsubsection{Bases Inmunológicas de las Reacciones Alérgicas}

En 1986, Mosmann y Coffman describieron por primera vez la existencia de dos tipos diferentes de poblaciones $\mathrm{CD}^{+}$, a las que llamaron Th1 y Th2, según su patrón de secreción de citocinas (19). 
La idea generalizada es que las bases inmunológicas de la sensibilización atópica y la enfermedad alérgica son el resultado de una respuesta de las células $T$ colaboradoras (helper) de tipo 2 (Th2) inapropiada frente a sustancias generalmente inocuas, conocidas como alérgenos. Algunas de las citocinas asociadas a esta respuesta son la IL-4 y la IL-13, importantes en la regulación de la producción de IgE. La IL-5, que contribuye en la inflamación eosinofílica característica de las reacciones alérgicas y se cree que las IL 9 y 13, son importantes para la hiperrespuesta bronquial (3) (Figura 1).

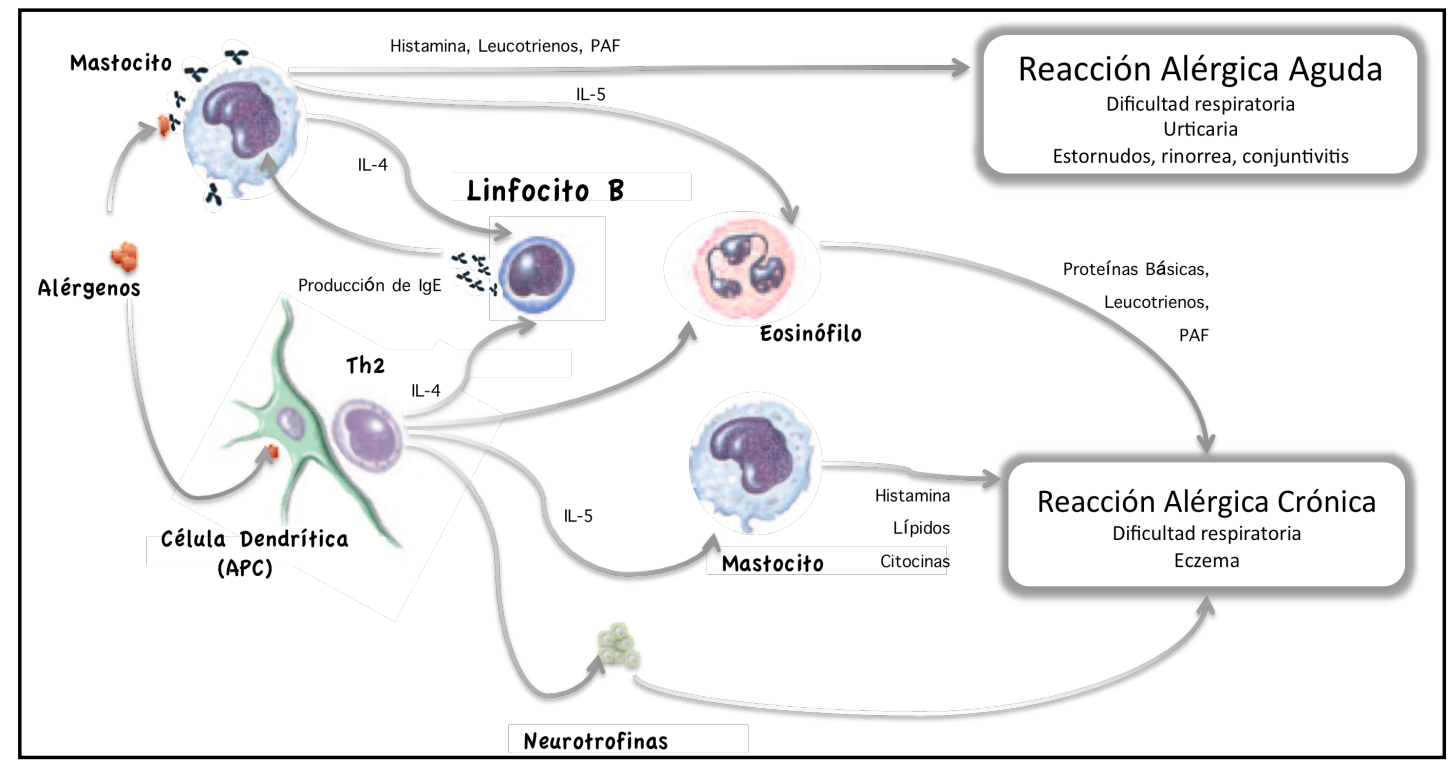

Figura 1 Representación esquemática de las células implicadas y mediadores implicados en la respuesta alérgica.

Una nueva variedad de células $\mathrm{T}$, conocidas como linfocitos $\mathrm{T}$ reguladores (Treg) ha entrado recientemente en escena. Este "nuevo" tipo celular se desarrolla de forma natural en el timo, gracias a la estimulación por IL-2, TGF $\beta$ y CD28 entre otros, o bien como de forma inducida en la periferia a partir de linfocitos T CD4 vírgenes (Treg adaptativos)(20). Los Treg mejor caracterizadas son linfocitos 
$\mathrm{CD}^{+}$que de forma constitutiva expresan elevados niveles del receptor de superficie CD25 (el receptor para la cadena $\alpha$ de la IL-2: CD25 hi T cells)(21).

Al contrario que linfocitos $\mathrm{CD}^{+}$, los linfocitos Treg CD25 hi no proliferan tras la estimulación, sino que suprimen activamente la proliferación y producción de citocinas de otras células T efectoras. Este "fenotipo supresor" se debe en parte a la expresión de elevados niveles del factor de transcripción Foxp3 y la expresión de IL-10 y TGF $\beta(22,23)$.

Se cree que estas células podrían desempeñar un papel importante en las enfermedades alérgicas. Tras separar las poblaciones linfocitarias $\mathrm{CD}^{+} \mathrm{CD}_{25} 5^{+} \mathrm{y}$ $\mathrm{CD}^{+}$CD25- de sangre periférica de individuos sanos se pudo comprobar que in vitro la población $\mathrm{CD}^{+}{ }^{+} \mathrm{CD} 25^{-}$respondía rápidamente a la estimulación antigénica, mientras que en presencia de la población $\mathrm{CD} 44^{+} \mathrm{CD} 25^{+}$la respuesta alérgica se inhibía (24).

\subsubsection{Linfocitos $B$}

Todos los leucocitos derivan de células madre hematopoyéticas de la médula ósea, pero maduran en los órganos linfoides periféricos en presencia de antígeno. En líneas generales, se pueden diferenciar dos etapas en el desarrollo de linfocitos B: la primera, que ocurre en ausencia de antígeno y la segunda, que es dependiente del antígeno (Tabla 2) (25).

Durante el proceso de maduración en la médula ósea y en ausencia de una estimulación antigénica específica, se genera un enorme repertorio de células $B$ que, en el ser humano, se estima que puede llegar a $1,5^{*} 10^{9}$ por día (26). Durante 
el desarrollo normal, la aparición del receptor BCR en la superficie celular define el estado de célula B inmadura (pre-pro B). Durante este proceso ocurre el reordenamiento génico de los segmentos V(D)J y se evalúa si las células se dirigen contra antígenos propios (27). Las células B que son reactivas frente a antígenos propios pueden llevar en este punto dos caminos: ser rescatadas mediante una segunda recombinación somática, proceso que se conoce como edición (editing) del receptor, o ser bien eliminadas, bien desactivadas mediante apoptosis o anergia, respectivamente (28).

La segunda fase del desarrollo linfocitario comienza cuando las células B maduras son estimuladas para llevar a cabo procesos de expansión clonal en los órganos linfoides periféricos. Estas células tienen una vida de aproximadamente cinco días desde que salen de la médula ósea, a menos que encuentren un antígeno(28).

En el caso de que estos linfocitos B vírgenes (naive) reconozcan algún antígeno, interaccionarán en primer lugar con linfocitos T específicos de antígeno, activando dos procesos: (i) el de hipermutación somática, con el fin de aumentar especificidad y afinidad del anticuerpo, y (ii) el de cambio de isotipo, que confiere diferentes funciones efectoras al anticuerpo. Los anticuerpos que son producidos durante este período tienen el único objetivo de aumentar la diversidad y afinidad de los mismos (27).

Los procesos de cambio de isotipo ocurren en los centros germinales, donde las células B expresan AID (de sus siglas en inglés Activation Induced cytidine Deaminase), que induce las mutaciones responsables de la maduración de la afinidad (29). 
Tabla 2. Marcadores de superficie durante las diferentes etapas del desarrollo de linfocitos B.

\begin{tabular}{|c|c|c|c|c|c|c|c|c|c|}
\hline & \multicolumn{5}{|c|}{ Fase independiente de Antígeno } & \multicolumn{4}{|c|}{ Fase dependiente de Antígeno } \\
\hline & $\begin{array}{l}\text { Célula } \\
\text { Pre-pro B }\end{array}$ & $\begin{array}{l}\text { Célula } \\
\text { Pro-B }\end{array}$ & $\begin{array}{l}\text { Célula } \\
\text { Pre B }\end{array}$ & $\begin{array}{c}\text { Célula } \\
\text { B inmadura }\end{array}$ & $\begin{array}{l}\text { Célula B } \\
\text { madura }\end{array}$ & $\begin{array}{l}\text { Célula B } \\
\text { activada }\end{array}$ & $\begin{array}{c}\text { Célula B } \\
\text { Blastocitaria }\end{array}$ & $\begin{array}{l}\text { Célula B } \\
\text { de } \\
\text { Memoria }\end{array}$ & $\begin{array}{c}\text { Célula B } \\
\text { plasmática }\end{array}$ \\
\hline MHC Class II & + & + & + & + & + & + & + & + & \\
\hline CD10 & + & + & & & & & + & & \\
\hline CD19 & + & + & + & + & + & + & + & + & \\
\hline CD20 & & + & + & + & + & + & + & + & \\
\hline CD21 & & & + & + & + & + & & & \\
\hline CD23 & & & & + & + & + & + & & \\
\hline CD25 & & & & & + & + & & & \\
\hline CD32 & & & & + & + & + & + & & \\
\hline CD34 & + & + & + & & & & & & \\
\hline CD35 & & & & + & + & + & + & + & \\
\hline CD40 & & + & + & + & + & + & + & + & \\
\hline CD80/86 & & & & & & + & + & & \\
\hline CD121 & & & & & & + & + & & \\
\hline CD122 & & & & + & + & + & + & + & \\
\hline CD123 & + & + & + & & & & & & \\
\hline CD124 & & & & + & + & + & & & \\
\hline CD125 & & & & & & + & + & & \\
\hline CD126 & & & & & & + & + & & \\
\hline CD127 & + & & & & & & & & \\
\hline
\end{tabular}

En el ser humano existen cinco clases diferentes de inmunoglobulinas, cada una caracterizada por su cadena pesada: $\mu, \delta, \gamma, \alpha, y \varepsilon$, que se corresponden, respectivamente con IgM, IgD, IgG, IgA e IgE. Además, hay cuatro subclases de IgG, conocidas como IgG1, IgG2, IgG3, IgG4 y dos subclases de IgA: IgA1 e IgA2. 
El cambio de isotipo a IgE es inducido por las citocinas IL-4 o IL-13 secretadas por células Th2 en humanos y por CD40L, que actúa como ligando para su respectivo receptor presente en las células $B(13,30)$.

Tras la activación, los linfocitos B maduros pueden sufrir diversos procesos de diferenciación según la intensidad de la señal y la presencia de otras células T. En un proceso de activación óptimo, las células B se diferencian en células B efectoras, que secretan anticuerpos y células B de memoria, proceso que tiene lugar en los centros germinales.

Como se ha comentado anteriormente, los linfocitos B son los encargados de producir anticuerpos y por tanto, los responsables de la inmunidad humoral. Los anticuerpos neutralizan patógenos y toxinas, facilitando la opsonización y activando el complemento. Además de reconocer péptidos solubles, son capaces de unirse a diferentes epítopos, entre los que se encuentran polisacáridos y ácidos nucleicos. En la mayoría de los casos, una infección primaria o una vacunación dan lugar a un proceso de maduración de la afinidad, una de las bases de la respuesta humoral.

Uno de los principales marcadores de linfocitos es el CD19. Esta proteína transmembranaria de $95 \mathrm{kDa}$ pertenece a la superfamilia de las inmunoglobulinas y se expresa de forma exclusiva en células B, tanto de ratón como de humanos (31, 32). Generalmente se encuentra formado complejos con el CD21, siendo ambos necesarios para la correcta diferenciación y funcionamiento de los linfocitos B (32) ya que actúan como potenciadores de las señales de activación y promueven la supervivencia celular. 
La molécula CD19 se expresa en células B desde la fase pre-B, antes del reordenamiento de las inmunoglobulinas (33), y es un factor crítico tanto en el desarrollo como en la diferenciación de células B (Tabla 2).

\subsubsection{Características de la Reacción Alérgica}

\subsubsection{Sensibilización alérgica}

En las respuestas de tipo I hay una fase previa de sensibilización. Así, en un primer contacto con el alérgeno, éste es captado por las células presentadoras de antígenos y procesado a péptidos que se expresan en las moléculas del Complejo Principal de Histocompatibilidad de clase II (MHC-II). Este complejo es presentado a los linfocitos $\mathrm{T}$, que lo reconocerán a través de su receptor clonotípico (TcR/CD3). A continuación, se produce la expresión de determinadas moléculas de co-estimulación, entre las que se encuentra CD154 (ligando del CD40, CD40L) en la superficie de los linfocitos $\mathrm{T}$, que se unirá a su respectivo receptor, CD40, presente en la membrana de los linfocitos B. Esta estimulación linfocitaria mediante TcR/CD3, MHCII, antígeno, CD40 y su ligando, desencadena una serie de reacciones que culminarán con la secreción de IgE por parte de linfocitos B. Entre estas reacciones secuenciales se encuentran la inducción de CD80/86, que interaccionará con CD28, presente en linfocitos T, y que promoverá la expresión de citocinas esenciales en esta respuesta, como la IL-4 e IL-13 (Figura 2) (13). 
La unión de la IL-4 e IL-13 a sus correspondientes receptores (IL-4R e IL-13R) presentes en la superficie celular de linfocitos B activará la cascada de transmisión de señales de STAT6 (Signal Transducer and activator of transcription 6), la cual, de forma sinérgica con el NF- $\kappa B$ (Factor nuclear $\kappa B$ ), activará la expresión de AID, promoviendo el cambio de isotipo de IgM a IgE (34).

La IgE se unirá a los receptores de alta sensibilidad FceRI presentes en mastocitos $\mathrm{y}$ basófilos, desencadenando en un nuevo contacto con el antígeno,

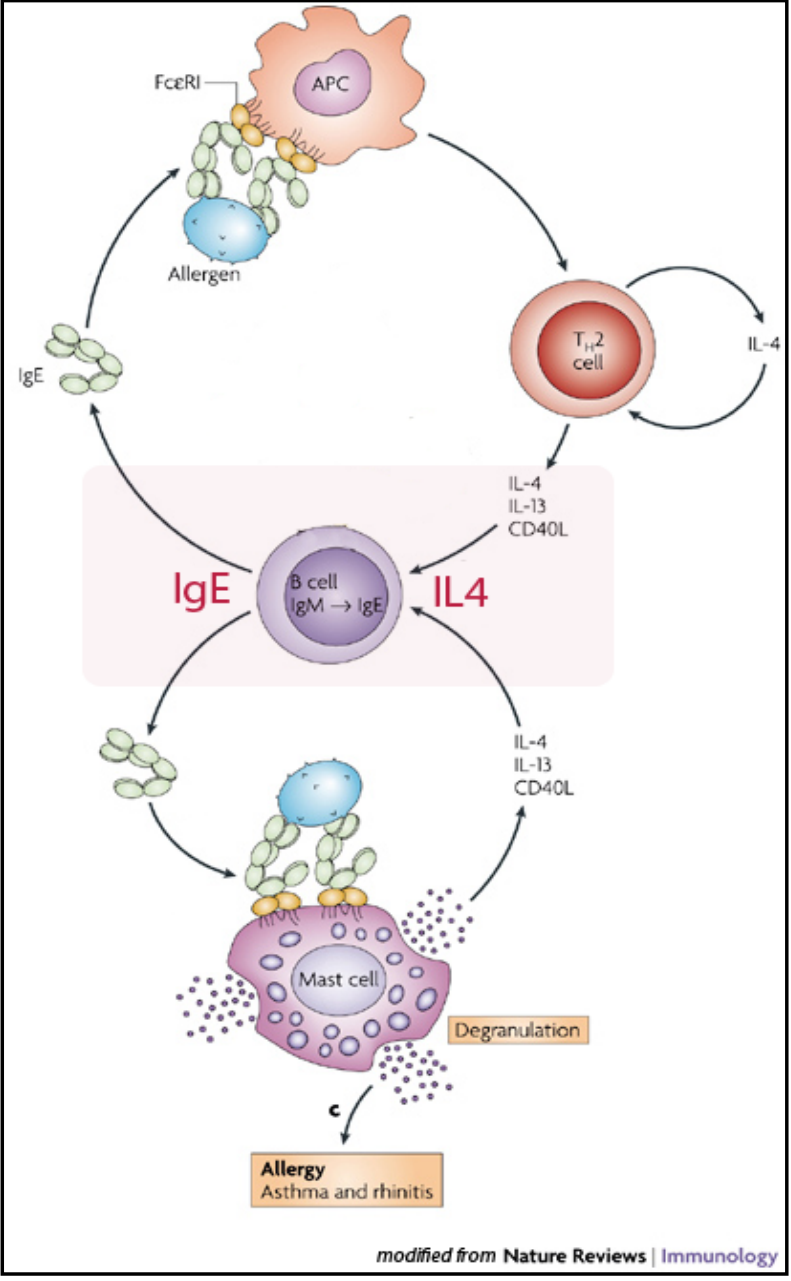

Figura 2. Cambio de isotipo de IgM a IgE en la respuesta alérgica. Modificado de Gould et al. (13) la liberación de los mediadores inflamatorios responsables de los síntomas característicos de la reacción alérgica.

Las respuestas de las células B están gobernadas por una integración de señales que reciben el receptor de células B (BCR, de sus siglas en inglés $B$ Cell Receptor) y otras moléculas de superficie. Mientras que los estudios in vivo demuestran que el reconocimiento del antígeno es necesario para una correcta activación de las 
células B, la presencia o ausencia de estas otras moléculas de superficie determinarán la respuesta de la célula tras la unión del BCR al antígeno (35).

En los pacientes con enfermedades alérgicas, la población de linfocitos B y de células plasmáticas de la mucosa del tracto respiratorio está, en su mayoría, destinadas a la producción de IgE. Aproximadamente el 4\% de los linfocitos B y el 12-19\% de las células plasmáticas expresan IgE en los pacientes con rinitis alérgica, mientras que en individuos sanos estas cifras descienden hasta el 1\% ó $<1 \%$ respectivamente $(36)$.

\subsubsection{Respuesta efectora en la reacción alérgica}

Tras la fase de sensibilización, un segundo contacto con el alérgeno puede desencadenar la respuesta efectora. Las reacciones alérgicas pueden presentarse de modo bifásico: una primera fase denominada respuesta inmediata, que aparece entre segundos y minutos tras la exposición al antígeno, y una fase tardía de la reacción, que se presenta entre 4 y 8 horas después. Por otro lado, puede aparecer una inflamación alérgica crónica como resultado de repetidas exposiciones al alérgeno $(3,37)$ (Figura 2 , sección anterior)

\subsubsection{Reacciones inmediatas}

Las reacciones de hipersensibilidad de tipo I ocurren pocos minutos después de la exposición al antígeno y conllevan la secreción de mediadores inflamatorios por los mastocitos en los sitios afectados. En individuos previamente sensibilizados, 
estas células presentan en su superficie receptores de alta afinidad para la $\operatorname{IgE}$ (FceRI). Cuando varias moléculas de IgE se unen a antígenos bi o multivalentes, se produce la agregación de los receptores FceRI, desencadenando una compleja red de transmisión de señales intracelulares cuyo resultado es la liberación del contenido de los gránulos mastocitarios, que almacenan diferentes tipos de productos biológicamente activos, entre los que destacan la histamina y los factores quimiotácticos; también se produce, en cuestión de minutos, la síntesis de mediadores lipídicos, como las prostaglandinas y los leucotrienos. El ácido araquidónico es metabolizado por las vías de la ciclooxigenasa y la lipooxigenasa, que dan como resultado compuestos conocidos como prostaglandinas (en particular la prostaglandina D2 (PGD2)), leucotrienos (LT, como el LTB4) y los leucotrienos cisteinílicos (cys-LT) y, a lo largo de horas, la de citocinas como la IL4 y la IL-13 (38).

Tanto los mediadores inflamatorios preformados como los sintetizados de novo son secretados tras la fusión de las membranas de los gránulos citoplasmáticos con la membrana plasmática mastocitaria, en un proceso que se conoce como desgranulación. Entre los mediadores liberados se incluyen aminas biogénicas (entre las que se encuentra la histamina), proteoglicanos (como la heparina), serín proteasas (como las triptasas o carboxipeptidasas) y otras citocinas o factores de crecimiento que se pueden encontrar asociados a los gránulos, entre los que se encuentran el Factor de Necrosis Tumoral alfa (TNF- $\alpha$, de sus siglas en inglés Tumour-Necrosis Factor- $\alpha$ ) o el Factor de Crecimiento Vascular Endotelial A (VEGFA, de sus siglas en inglés Vascular Endothelial Growth Factor $\underline{\text { A) }}$ (38-40). 
La liberación de los mediadores anteriormente descritos es responsable de los síntomas característicos de la fase inmediata de las reacciones alérgicas. Estos síntomas, que pueden variar según el lugar de la reacción, incluyen vasodilatación (como reflejo de la acción de los mediadores que actúan en nervios locales, produciendo eritema en la piel y la conjuntiva), aumento en la permeabilidad vascular (lo que produce edema y lagrimeo), contracción del músculo liso bronquial (y como consecuencia obstrucción de las vías respiratorias y tos), y aumento de la secreción mucosa (exacerbando la obstrucción de las vías respiratorias). Además, estos mediadores pueden estimular también nociceptores y nervios de sensibilidad de la nariz (41), la piel (42) o las vías respiratorias en general (43), lo que resulta en síntomas tan característicos como estornudos, picores o tos.

\subsubsection{Fase tardía}

La respuesta estimulada por la interacción IgE-alérgeno en los mastocitos conlleva tanto la liberación de factores quimiotácticos, citocinas, quimiocinas y factores de crecimiento sintetizados previamente (liberados en la reacción temprana), como la síntesis de nuevos mediadores inflamatorios, que son liberados de forma paulatina, constituyendo la respuesta tardía (44).

Durante la fase tardía de las reacciones alérgicas se induce la síntesis de prostaglandinas, leucotrienos y diferentes citocinas por parte de mastocitos y basófilos activados. Entre las moléculas que se liberan en esta etapa se encuentran además el TNFa, el LTB4, la IL-8 (también conocida como CXCL8) o ligando de quimiocinas CC2 (CCL2), moléculas capaces de recluir otras células inmunitarias, 
activar células responsables de la inmunidad innata (mediante TNF $\alpha$ e IL-5), o activar diversos mecanismos biológicos que afectan a las células dendríticas, linfocitos T y linfocitos B, mediante la actividad de IL-10, TNF $\alpha$, TGF $\beta$ o histamina $(2,39)$.

Se sabe que la coordinación de las reacciones tardías se debe, por una parte, a los efectos de los mediadores liberados por los mastocitos y los basófilos en las reacciones tempranas y por otra, a la síntesis de nuevos mediadores inflamatorios y al reclutamiento de otras células inmunitarias, entre las que se encuentran neutrófilos, monocitos, eosinófilos y basófilos y a la presencia y activación de linfocitos T, capaces de reconocer péptidos antigénicos presentes en el lugar de la reacción (2). Las características clínicas de estas reacciones ponen de manifiesto la contribución tanto de células previamente residentes en el tejido dañado como de células leucocitarias circulantes reclutadas durante el transcurso de la reacción inflamatoria. Por ejemplo, la vasodilatación asociada que ocurre en esta fase se podría explicar, en parte, por la secreción de calcitonina por parte de células epiteliales, linfocitos $\mathrm{T}$ y mastocitos, entre otros (45).

Estas reacciones generalmente ocurren de 2 a 6 horas tras la exposición al alérgeno, con un pico transcurridas alrededor de las 6 o 9 horas. El hecho de que este tipo de reacciones no aparezca en todos los individuos sensibilizados no está del todo clara, al igual que tampoco está claro por qué en otros pacientes no hay una distinción clara entre la finalización de una fase y el comienzo de la siguiente (3). 


\subsubsection{Inflamación alérgica crónica}

Cuando la exposición a un alérgeno se produce de forma continua o repetida, muchas células de la inmunidad innata o adaptativa que, en condiciones normales se encuentran en el torrente sanguíneo, pueden extravasarse a los tejidos afectados. La inflamación persistente característica de este tipo de exposiciones conlleva cambios estructurales tisulares, lo cual compromete el correcto funcionamiento de los órganos afectados (46).

A pesar de que tanto la fase inmediata como la tardía pueden estudiarse de forma relativamente fácil en personas afectadas, la mayoría de los estudios sobre inflamación alérgica crónica están realizados en modelos animales, ninguno de los cuales puede considerarse como una reproducción exacta de las reacciones humanas. Por tanto, no resulta demasiado extraño que aún no se sepa cómo después de una exposición persistente a un alérgeno la inflamación local del tejido pase, de una fase temprana o tardía, a una fase de inflamación crónica (2).

Se sabe que individuos con asma crónica pueden tener afectadas todas las capas del tracto respiratorio, asociándose típicamente con cambios en el epitelio, lo que se refleja en un aumento de células caliciformes (que conllevará un aumento en la producción mucosa), un aumento en la producción de citocinas y quimiocinas por células epiteliales y zonas del epitelio que hayan resultado dañadas entre otros (47). 
En los individuos con asma, las infecciones por virus respiratorios como los rinovirus o el virus de la gripe son capaces de producir una marcada exacerbación de los signos y síntomas de asma (48).

En casos de dermatitis atópica (49) y rinitis alérgica (50), así como en los de asma, la inflamación alérgica crónica está asociada con la remodelación tisular. Esta remodelación puede conllevar cambios persistentes en los elementos estructurarles de las zonas afectadas (como un incremento en la vascularización), así como alteraciones sustanciales en la función de barrera del epitelio afectado.

\subsubsection{Alergia a los Acaros del Polvo}

Los ácaros del polvo pertenecen al orden de los artrópodos y reciben su nombre del griego akarés "diminuto", "que no se corta". En la actualidad existen casi 50.000 especies descritas, y se estima que pueden existir entre 100.000 y 500.000 especies que todavía no han sido clasificadas (51).

Entre las diferentes especies implicadas en patología humana, quizá los mejor conocidos sean los ácaros del polvo, probablemente debido a su gran abundancia. Están presentes en la mayoría de los hogares, habitando en lugares tan comunes como ropa de cama, muebles, alfombras (moquetas), y muñecos de peluche. Los lugares cálidos y húmedos (con una humedad relativa superior al 50\%) constituyen un hábitat óptimo, alimentándose tanto de pequeñas descamaciones cutáneas como de otras materias orgánicas (52). 
Las especies mejor estudiadas por su elevado componente alergénico son las que pertenecen a la familia Pyroglyphidae, en especial Dermatophagoides pteronyssinus (ver Figura 3), D. farinae y Euroglyphus maynei. A pesar de que se conocen otras especies capaces de desencadenar reacciones alérgicas, su estudio es más limitado, ya que su presencia en ambientes domésticos es también más reducida (53).

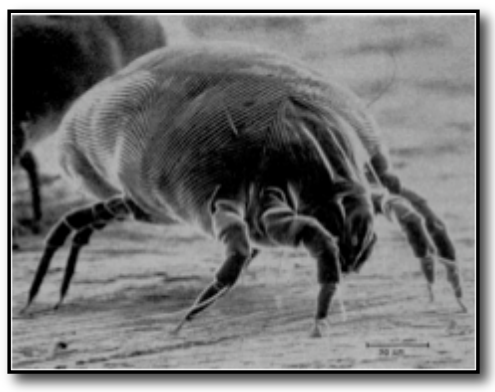

Figura 3 Imagen a microscopio electrónico de $D$. pteronyssinus. Las medidas del ácaro oscilan entre los 420 micrómetros de largo y 250 o 320 micrómetros de ancho.

\subsubsection{Prevalencia de las Enfermedades Alérgicas}

La prevalencia de las enfermedades alérgicas aumentó un 75\% entre 1980 y 1998 (54). A pesar de que aún no se dispone de una explicación satisfactoria para esta tendencia epidemiológica, existe consenso en que no se debe solamente a cambios genéticos de la población sino al efecto conjunto de éstos con determinados factores ambientales. Esta circunstancia ha sido materia de intensas especulaciones, a lo que se añade, además, el hecho de que los mecanismos patogénicos de la enfermedad y la contribución de los factores genéticos son aún poco conocidos (55).

Hoy en día se piensa que aproximadamente 300 millones de personas en el mundo padecen asma (56). Se piensa que alrededor de 50 millones de estadounidenses (1 
de cada 5) sufren algún tipo de alergia, entre los que se incluyen alergias alimentarias, a fármacos, látex, insectos, pólenes, ácaros así como enfermedades alérgicas cutáneas u oculares (57). Las enfermedades alérgicas en Estados Unidos ocupan la quinta posición entre las enfermedades crónicas más comunes, y la tercera posición entre las enfermedades crónicas más comunes en niños menores de 18 años (58).

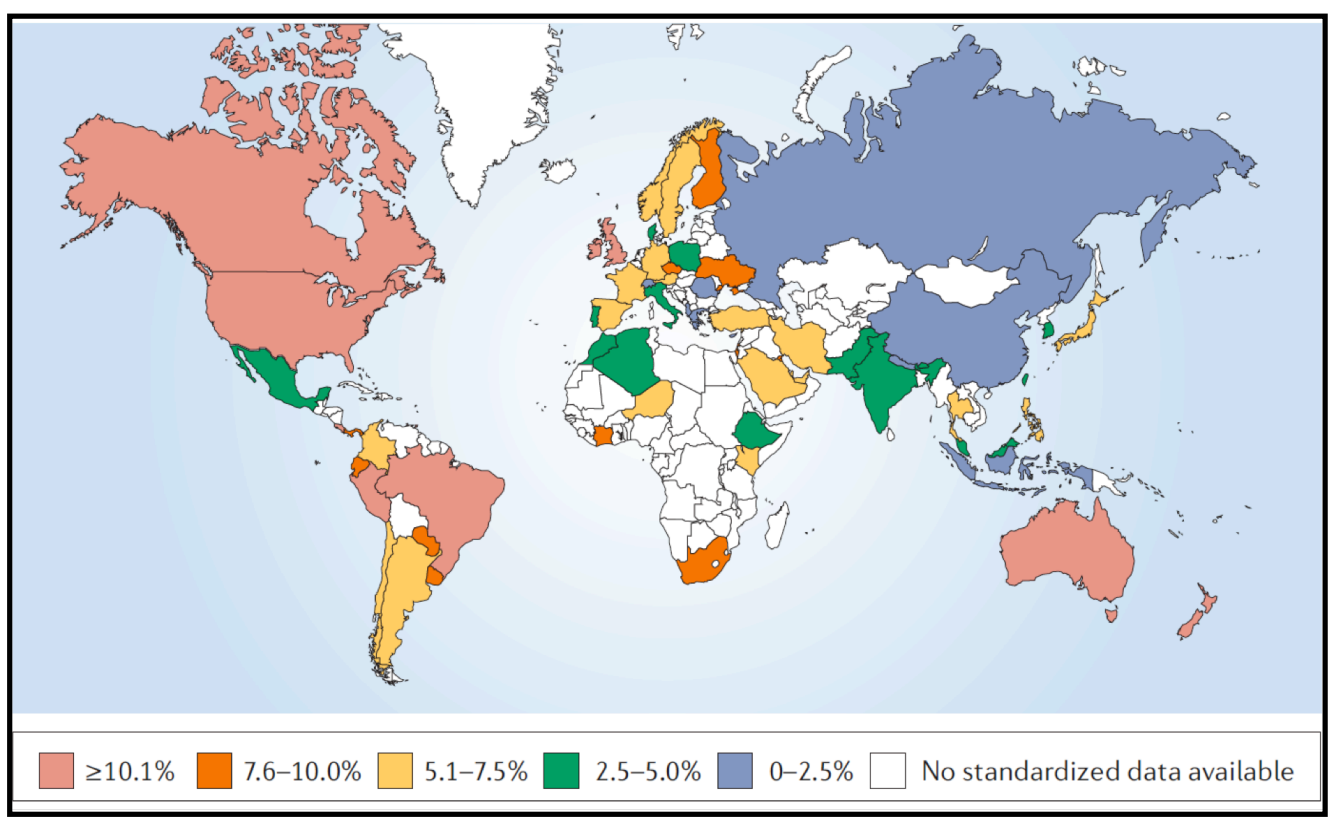

Figura 4 Variación de la prevalencia de asma entre diferentes países. Los números indican el porcentaje de individuos de cada país que sufren de asma (54).

En un estudio realizado en Gran Bretaña en 1992 en el que se compararon 2510 niños estudiados en el año 1964 con 3403 niños estudiados en 1989, la prevalencia del asma pasó del 4,1\% al 10.2\%, la rinoconjuntivitis polínica del 3,2\% al 11,9\%y la dermatitis atópica del 5.3\% al 12\% (59). 
En un estudio observacional de tipo transversal realizado en España y publicado en 2004 se estimó que la prevalencia de las enfermedades alérgicas en adultos rondaba el 21,6\% (aproximadamente uno de cada cinco sujetos sufre algún tipo de alergia o patología relacionada). La prevalencia es mayor en las mujeres que en hombres y el número de casos es mayor cuanto mayor es la ciudad. Entre las principales causas referidas se encontraron los pólenes, los ácaros del polvo doméstico y los medicamentos (60).

Las enfermedades alérgicas constituyen el motivo de visita médica más frecuente en niños, con síntomas que limitan sus actividades diarias en más de un 40\% de los casos.

En un estudio publicado en 2001, se estimó que, cada año, cerca de 400 estadounidenses mueren debido a reacciones alérgicas a la penicilina, 200 mueren debido a complicaciones por alergia alimentaria, 100 debido a picaduras de insectos y 10 debido a complicaciones graves de alergia al látex (61). Además, se estima que aproximadamente 11 estadounidenses mueren por asma al día, lo que suma más de 4000 muertes al año, además de otras 7000 muertes en las que el asma aparece como enfermedad grave relacionada con la causa de la defunción (62).

El coste total sanitario de las diferentes enfermedades alérgicas se estima alrededor de los 7.000 millones de dólares, sólo en los Estados Unidos, de los cuales aproximadamente 5.700 millones de dólares se destinan a los costes de los tratamientos. Además, las enfermedades alérgicas constituyen la quinta enfermedad crónica responsable de absentismo laboral, lo que resulta, en 
términos generales, en 4 millones de días de trabajo perdidos, ascendiendo la pérdida a más de 700 millones de dólares de pérdida en productividad (58).

El coste anual en el sistema sanitario de Estados Unidos destinado a pacientes asmáticos asciende a los 18.000 millones de dólares (63). 


\subsubsection{Introducción}

El término "epigenética", descrito por primera vez por Conrad Waddington en 1939 (64), surge de la combinación del prefijo en latín "epi", literalmente traducido como "sobre" y la palabra genética, que proviene del griego y significa "descendencia" en un intento por explicar la interacción entre la información genética y el ambiente.

De una forma más concreta, se puede englobar bajo este término una gran variedad de mecanismos que ejercen efectos a largo plazo en los programas de expresión génica y que ocurren sin alterar la secuencia de pares de bases descrita por Watson y Crick (65). Entre estos mecanismos se encuentran la metilación de citosinas (66), la modificación química de histonas y las variantes de histonas que, junto con los complejos de remodelación de nucleosomas dependientes de ATP (67), los complejos polycomb/trithorax y una gran variedad de RNA no codificantes entre los que se encuentran los siRNA (small interference RNA) y los miRNA (microRNA), definen la estructura de la cromatina en un locus particular y así, su posible actividad transcripcional.

Todas las células que forman un organismo multicelular comparten la misma información genética, y es ésta información la que tiene que dar respuesta a fenotipos y funciones muy diversas y específicas. En raras ocasiones, el DNA lleva a cabo procesos de hipermutación (el caso de generación de diversidad de inmunoglobulinas en los linfocitos B es una clara excepción), siendo organizado de 
forma pasiva por estos mecanismos, que son los encargados de regular la expresión de diferentes grupos de genes, según el tipo celular.

\subsubsection{Histonas}

Las histonas son proteínas básicas de bajo peso molecular muy conservadas evolutivamente. Se conocen cinco clases de histonas (H1, H2A, H2B, H3 y H4) que se encuentran formando octámeros (dos unidades de H2A, H2B, H3 y H4) alrededor de los cuales se enrolla el ADN. Esta unidad se conoce como nucleosoma y entre cada nucleosoma se encuentra otra histona, la $\mathrm{H} 1$, encargada de interaccionar con el DNA internucleosomal. Las modificaciones postraduccionales que tienen lugar en las histonas constituyen uno de los principales puntos de control epigenético conocidos.

Los mecanismos mediante los cuales la metilación de citosinas, comentado más adelante, conlleva un silenciamiento génico están íntimamente ligados a modificaciones covalentes de estas proteínas. Este proceso se lleva a cabo mediante el reclutamiento directo por parte de las Metiltransferasas del DNA (DNMT, de sus siglas en inglés DNA Methyl Transferases) de las enzimas responsables de estas modificaciones postraduccionales (68), entre las que se encuentran las acetil transferasas de histonas (HAT), las histonas desacetilasas (HDAC) o las metiltransferasas (HMT).

Diferentes combinaciones de estas modificaciones en el extremo amino-terminal de estas proteínas tienen consecuencias funcionales, que afectan a la actividad génica y la organización de la cromatina (69). Las consecuencias funcionales de estas modificaciones dependen del tipo de residuo y la posición afectada: la 
metilación de la lisina 4 de la histona H3 (H3K4) (70) y de la arginina 17 (H3R17) (71) son marcadores de actividad transcripcional, mientras que la metilación de la lisina en posición 9 de la misma histona se asocia con silenciamiento transcripcional (72).

\subsubsection{Metilación del DNA}

En los seres humanos, la adición de grupos metilo en el DNA ocurre de forma simétrica en ambas cadenas del DNA, casi exclusivamente en el carbono situado en la posición 5 de citosinas que se encuentran seguidas de guanina (CpG) (73).

Estos dinucleótidos se encuentran en una frecuencia menor de la esperada en el genoma (74), probablemente debido a un proceso de desaminación espontánea de las citosinas metiladas a timinas $(\mathrm{CpG} \rightarrow \mathrm{TpG})$, lo que las convierte especialmente sensibles a mutaciones o deleciones. Otros tipos de metilación como la que ocurre en las citosinas que se encuentran en un contexto $\mathrm{CpNpG}$ o $\mathrm{CpA}$ se han descrito en células madre embrionarias de ratón y plantas, pero son raras en tejidos somáticos humanos (73).

\subsubsection{Distribución Genómica}

En ciertas zonas del genoma, los dinucleótidos CpG se encuentran formando lo que se conocen como islas $\mathrm{CpG}$, que se definen de forma teórica como regiones de al menos 200 pares de bases, en las que el contenido de $\mathrm{C}+\mathrm{G}$ es superior al $50 \%$ y presentan una ratio esperada/observada superior a 0.6. Aproximadamente tres cuartas partes del total de los sitios de inicio de la transcripción (TSS, de sus siglas 
en inglés Transcription Start Site) y el 88\% de los promotores activos del genoma se asocian con secuencias ricas en $\mathrm{CpG}$, y se encuentran sujetos a regulación mediada por metilación (75).

Sólo el 1-2\% del genoma total está formado por islas CpG situadas alrededor de la zona promotora de algunos genes que escapan a los procesos de silenciamiento génico mediante metilación (76). Aproximadamente la mitad de las islas CpG del genoma se encuentran en zonas que no corresponden a promotores de genes anotados, sino que se encuentran en regiones intra o inter genómicas, abriendo la posibilidad de que correspondan a sitios de inicio de transcripción del RNA no codificantes (77). Esta teoría se ve apoyada por la observación de que en diferentes tipos de tumores se detecta un aumento anormal de la expresión de numerosos miRNA que se encuentran asociados a zonas de metilación aberrante (78).

\subsubsection{Enzimas responsables}

La transferencia de grupos metilo depende tanto de la presencia de donantes (metionina y colina) como de cofactores (ácido fólico, vitamina B12 o piridoxal fosfato) que sinteticen el donante universal de grupos metilo, la S-adenosín-L metionina (SAM). Durante las reacciones de metilación un grupo metilo se transfiere enzimáticamente desde SAM a la posición C5 de una citosina, dejando como producto intermedio la S-adenosilhomocisteina, la cual, a elevadas concentraciones, inhibe la acción de las DNA metiltransferasas (DNMT). 
En el ser humano se han descrito cinco DNMT (DNMT1, DNMT2, DNMT3A, DNMT3B y DNMT3L) encargadas de catalizar las reacciones de metilación de citosinas, involucradas bien en procesos de mantenimiento, bien en procesos de metilación de novo. Estas enzimas han resultado ser esenciales durante el desarrollo embrionario, como se ha demostrado en distintos modelos animales (66).

Se sabe que la DNMT1 está involucrada en el mantenimiento de la metilación durante la división celular, ya que actúa sobre sustratos hemimetilados. Se localiza en la horquilla de replicación durante la fase $\mathrm{S}$ del ciclo celular y metila las citosinas de la hebra recién sintetizada utilizando la parental como plantilla (66).

Los embriones de ratón carentes de esta enzima presentan una reducción de los niveles de metilación que se aproxima al 70\% cuando se comparan con los niveles de metilación global fisiológicos. Además, estos ratones mueren antes del undécimo día de gestación y los estudios histológicos confirman una extensa muerte celular y una reducción de la proliferación celular (79).

Los mecanismos que controlan los procesos de metilación de novo son, en su mayoría, desconocidos. Las metiltransferasas involucradas son la DNMT3A y la DNMT3B. Se sabe que estas enzimas actúan preferentemente sobre secuencias concretas y que, a pesar de presentar funciones superpuestas, son incapaces de reemplazar sus funciones: la DNMT3A y la DNMT3L están involucradas en la metilación de regiones con marcado genómico (imprinting), mientras que la DNMT3B se encuentra principalmente en zonas repetitivas del genoma (80). 
Los ratones nuligénicos (knock-out) para DNMT3A presentan deficiencias durante el desarrollo embrionario y mueren a las tres o cuatro semanas después del nacimiento, mientras que los ratones carentes de DNMT3B presentan un fenotipo más grave y mueren antes del día 18 de gestación. Los ratones nuligénicos para ambas enzimas, DNMT3A y DNMT3B, no superan las primeras fases del desarrollo embrionario y mueren tras la gastrulación (81).

La DNMT2 es una de las metiltransferasas mejor conservadas evolutivamente, con homólogos en especies como Schizosaccharomyces pombe (82) o Drosophila melanogaster (83). Sin embargo, no se ha descrito in vitro una actividad detectable de estas enzimas, bien porque para su actividad requieran cofactores específicos, bien porque presenten preferencia por secuencias de DNA concretas no conocidas aún (84) o, por último, porque, como se ha sugerido, puedan actuar como una RNA metiltransferasa $(85,86)$. A pesar de que los ratones nuligénicos para esta enzima no presentan ningún defecto en los procesos de metilación, por lo que ha sido considerada como no esencial para el desarrollo en los mamíferos (85), los estudios realizados con su homóloga en Drosophila melanogaster han demostrado que resulta crítica en el silenciamiento de retrotransposones y en el control de la integridad de los telómeros (87).

La metilación del DNA está muy relacionada con otros eventos que median el silenciamiento transcripcional. Actualmente se conocen diferentes proteínas con dominios que reconocen y se unen al DNA metilado (MBD1-4, de sus siglas en inglés Methyl-Binding Domains) o proteínas de unión a CpG (MeCP2) que intervienen en la reclusión de otros correpresores transcripcionales, como los complejos histona desacetilasa, las proteínas polycomb y complejos que 
intervienen en la remodelación de la cromatina (80). Además de estas proteínas con dominios de unión específicos a DNA metilado, se sabe que las citosinas metiladas también pueden interaccionar con proteínas como Kaiso, ZBTB4 o ZBTB38, que presentan dominios en dedos de zinc y que también se asocian con represión de la transcripción (88).

A pesar de que no hay duda sobre la existencia de procesos de desmetilación durante el desarrollo, los mecanismos subyacentes no están del todo claros. La desmetilación podría ocurrir mediante mecanismos de sustitución de citosinas metiladas por citosinas sin metilar mediante una glicosilasa (Gadd45a) (89) o gracias a la MBD2, capaz de catalizar la hidrólisis de 5-metilcitosina (90), aunque existe cierta controversia al respecto. Lo más probable es que este proceso ocurra mediante procesos de desaminación llevados a cabo por enzimas de reparación del DNA, como AID o Gadd45a (91).

\subsubsection{Fisiología de la Metilación del DNA}

\subsubsection{Metilación del DNA y enfermedad}

En los mamíferos, las modificaciones epigenéticas desempeñan un papel esencial en el mantenimiento de los programas de transcripción celular y en la organización de la arquitectura del DNA dentro del núcleo. Se sabe que las aberraciones en el epigenoma pueden dar lugar a diferentes enfermedades, algunas relacionadas con patologías durante el desarrollo, otras asociadas con el desarrollo de cáncer (92). 
A pesar de que es en el cáncer donde mejor está caracterizada la relación entre aberraciones epigenéticas y enfermedad, se conocen otras enfermedades también relacionadas con alteraciones en el epigenoma, como el síndrome de Rett. Este trastorno neurológico afecta principalmente a mujeres y se debe a la presencia de mutaciones en el gen MeCP2 (methyl CpG-binding protein 2), cuya proteína, como se ha comentado anteriormente, está relacionada con el reconocimiento de dinucleótidos CpG metilados. En este síndrome, a pesar de que los procesos de metilación no se ven afectados, sí lo hacen los de reconocimiento de los mismos, lo que afecta a la organización de la cromatina y a la regulación de la expresión genética (93).

\subsubsection{Inactivación del cromosoma $X$}

El silenciamiento aleatorio de uno de los dos cromosomas $\mathrm{X}$ en las hembras de los mamíferos es uno de los grandes enigmas que se plantean al entender la transmisión estable y hereditaria de la información epigenética en las células somáticas.

En los mamíferos, el sexo se determina mediante un par de cromosomas heteromórficos conocidos como X e Y. Las hembras presentan dos copias del cromosoma $\mathrm{X}(\mathrm{XX})$ y los machos presentan una copia del

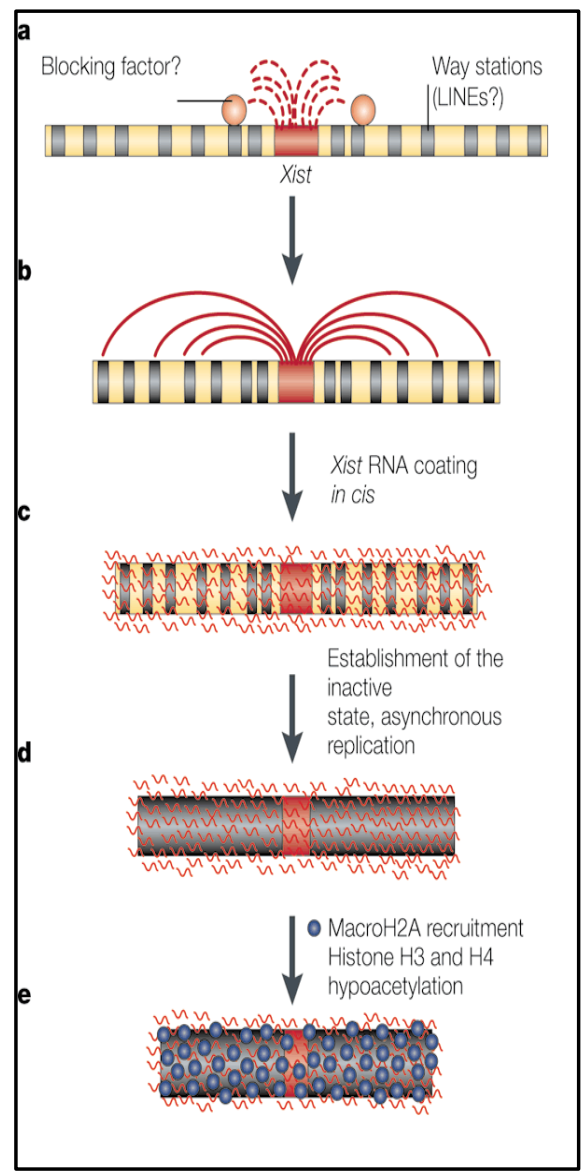

Figura 5. Representación del modelo actualmente aceptado para el comienzo de inactivación del cromosoma X (94). 
cromosoma X y otra del Y (XY). La compensación de la dosis génica del cromosoma $\mathrm{X}$ se consigue gracias a un proceso de silenciamiento transcripcional de uno de los dos cromosomas $\mathrm{X}$ en un proceso conocido como inactivación del cromosoma $\mathbf{X}$. Este proceso ocurre en los primeros estadios del desarrollo embrionario de las hembras, aproximadamente durante la implantación, y es estable durante el posterior desarrollo.

Estos procesos están controlados por el centro de inactivación del cromosoma X o Xic (de sus siglas en inglés $X$-chromosome-inactivation), que comprende alrededor de $1 \mathrm{Mb}$ de longitud y contiene varios elementos implicados en la inactivación del cromosoma X y al menos cuatro genes (Figura 5a) (94).

Uno de estos genes, conocidos como Xist, de sus siglas en inglés $X$ (inactive)specific transcript, se expresa únicamente en el cromosoma que va a ser inactivado, produciendo un transcrito poliadenilado de aproximadamente $17 \mathrm{~kb}$ (95) (Figura 5b). A pesar de que no está involucrado en la selección del cromosoma que se expresará, se cree que es uno de los primeros procesos que ocurren durante la inactivación. El Xce, otro gen que recibe el nombre de sus siglas en inglés $X$-chromosome-controlling element, está involucrado en la elección del cromosoma que será inactivado (96). A pesar de que no está claro cómo se produce la selección, parece ser que el proceso no es completamente aleatorio, ya que en la mayoría de los casos es el cromosoma paterno el que sufre la inactivación. El gen TsiX se expresa en células embrionarias y se piensa que controla la expresión de Xist durante el proceso de inactivación. El locus en el que se encuentra DXPas34 se caracteriza por ser una zona rica en CpG, que se encuentran hipermetiladas en el cromosoma X activo de las células somáticas (95). 
El silenciamiento transcripcional que ocurre en el cromosoma $X$ se produce por el revestimiento de Xist (Figura $5 \mathrm{c}$ ). La remodelación de la cromatina, mediante procesos como la desacetilación y metilación de histonas de promotores de los genes localizados en el cromosoma $X$ que será inactivado, así como el reclutamiento de la variante de histonas macroH2A, parece que transforman el silenciamiento temporal provocado por Xist en un silenciamiento estable de cromatina condensada (Figura 5d) (97).

\subsubsection{Marcado genómico (Imprinting)}

Los organismos diploides, entre los que se encuentran los mamíferos, presentan dos copias de los cromosomas autosómicos, uno de cada progenitor. En la mayoría de los casos, la expresión de los alelos es independiente del origen materno o paterno. Sin embargo, algunos genes son expresados de forma asimétrica según sean maternos o paternos, exhibiendo lo que se conoce como marcado, sellado genómico o imprinting.

Este fenómeno epigenético se conserva en los euterios, mamíferos vivíparos en los que el desarrollo embrionario ocurre dentro del útero materno, recibiendo así una alimentación mediada por una placenta alantoica. Los defectos en los procesos de marcado genómico se asocian con defectos en el desarrollo embrionario y neonatal, que pueden resultar entre otros, en defectos neurológicos, como en el caso del síndrome de Prader-Willy (98).

Los genes que están regulados por estos mecanismos se encuentran formando agrupaciones (clusters) que varían en tamaño (de 100 a $3000 \mathrm{~kb}$ ), con genes que 
codifican diferentes proteínas y al menos un gen que codifique un ncRNA (de sus siglas en inglés Non Coding RNA) (99).

Generalmente, la expresión de los genes en cada agrupación está regulada por un elemento que actúa en cis, conocido como ICR, de sus siglas en inglés Imprinting Control Region (100). Los ICR se caracterizan por ser zonas del genoma ricas en CpG que se encuentran metiladas de forma diferencial entre los alelos parentales. Estas zonas, conocidas como DMR (de sus siglas en inglés Differentially Methylated Regions) pueden ser mantenidas durante toda la vida o pueden sufrir modificaciones durante el desarrollo, presentando un patrón de marcado genómico específico de tejido $(101,102)$.

El marcado genómico se adquiere durante la gametogénesis. Antes de la determinación del sexo, las marcas del marcado genómico se "borran" en las células germinales que se han formado en la gónada embrionaria. Durante el desarrollo embrionario, como macho o hembra, las huellas del marcado genómico reaparecen en los alelos paternos, en el caso de la producción de esperma, o en los alelos maternos, en el caso de la formación de los óvulos. Después de la fertilización, el marcado genómico se mantiene durante las divisiones celulares posteriores (103) (Figura 6).

Se sabe que el establecimiento del marcado genómico en los gametos se lleva a cabo por la DNMT3A (104). Otro miembro de la familia, DNMT3L, es esencial para el establecimiento de las marcas de marcado genómico en las células germinales femeninas, mientras que la interrupción de esta enzima en los gametos masculinos 
se asocia con un fallo en el proceso de meiosis debido a reactivación de retrotransposones $(105,106)$.

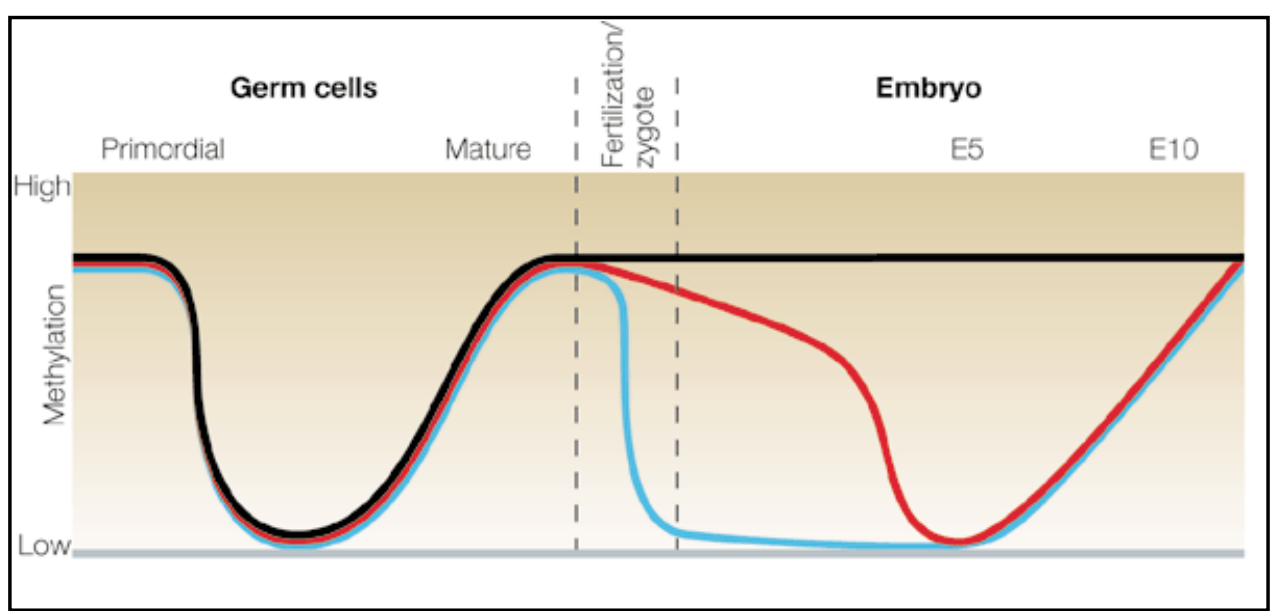

Figura 6. Niveles de metilación (negro) y no metilación (gris) de loci que sufren marcado genómico y de aquellos que no (rojo, materno; azul paterno) durante el desarrollo embrionario. En el eje de ordenadas se representa el porcentaje de metilación y en el de abscisas el tiempo (103).

La metilación del DNA es un importante mecanismo asociado con los fenómenos de marcado genómico, pero no es el único, ya que también las histonas presentan modificaciones asociadas a este fenómeno. Actualmente se conocen unos 50 genes en humanos, aunque predicciones bioinformáticas estiman un número mayor, que rondaría los 200 genes regulados por marcado genómico

\subsubsection{Transposones y elementos móviles del genoma}

Aproximadamente el $45 \%$ del total del genoma humano está compuesto por transposones (TE, de sus siglas en inglés Transposable Elements) y elementos móviles que, tras ser considerados erróneamente como DNA basura, han pasado a 
ser considerados como uno de los principales mecanismos de estabilidad genómica (107). Dentro de las familias de elementos repetitivos se encuentran los LTR-retrotransposones (Long Terminal Repeats), LINE (Long Interspersed Nuclear Elements), SINE (Short Interspersed Nuclear Elements) y los transposones (108). Estos elementos móviles pueden interferir en la estructura y regulación de la expresión génica mediante inserciones, eliminaciones (deleciones) o inversión de secuencias (109).

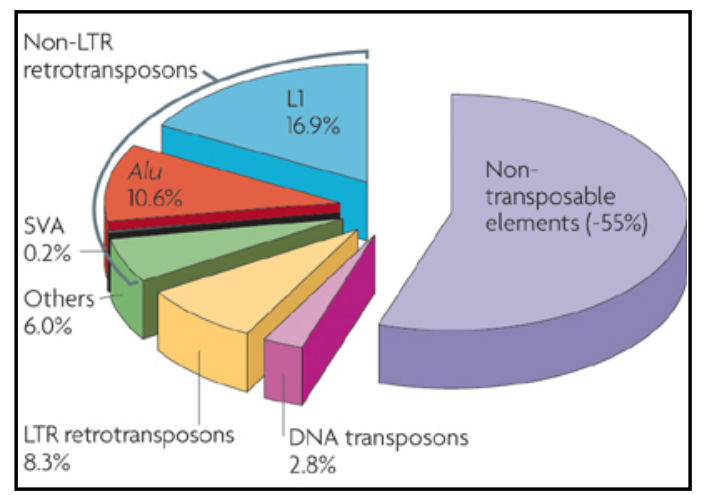

Figura 7. Aproximadamente el $45 \%$ del genoma humano se puede clasificar dentro de la categoría de elementos móviles del genoma. La mayoría de estos elementos corresponden a LTR (108).

Los retrotransposones necesitan la ayuda de una transcriptasa inversa para moverse por el genoma y se pueden dividir en dos familias, según tengan o no elementos repetitivos al final (LTR, de sus siglas en inglés Long Terminal Repeat). Los elementos LINE representan aproximadamente un $17 \%$ del total del genoma humano y se caracterizan por no presentar LTR y ser autónomos para la transposición (110). Por su parte, los elementos SINE son secuencias cortas $(<500$ bases) que no son autónomas y tampoco presentan LTR. Dentro de éstos, los elementos Alu son los más comunes, representando aproximadamente el 10\% del total del genoma (111). 
Los transposones del DNA no necesitan la ayuda de una transcriptasa inversa para integrarse en el genoma. En cambio, una proteína codificada por el propio transposón, conocida como trasposasa, puede reconocer determinadas secuencias conocidas como TIR (de sus siglas en inglés Terminal Inverted Repeat) para la integración del segmento. Hasta ahora, no hay pruebas de la presencia de transposones activos de DNA, aunque se han encontrado datos de esta actividad en el pasado (107).

A pesar del daño potencial que estas secuencias podrían causar en el genoma, sólo una de cada 600 mutaciones que tienen lugar en las células germinales en el ser humano se deben a la acción de estos elementos móviles, ya que se encuentran en zonas heterocromáticas (112). Estudios realizados con moscas de la fruta (113) y embriones de ratones (114) carentes de DNMT1 sugieren que la metilación de las citosinas y las modificaciones de las histonas son las responsables del silenciamiento de estos elementos.

\subsubsection{Estrategias para el estudio del Epigenoma}

El genoma de los organismos eucariotas se encuentra empaquetado en nucleosomas que constituyen la unidad básica de la cromatina, la forma fisiológica en la que el DNA se encuentra en el núcleo celular. Además de compactar el DNA, son un elemento fundamental en la regulación y el mantenimiento de los patrones de expresión genéticos.

La incorporación al estudio del epigenoma de técnicas como las micromatrices (microarrays) o la secuenciación masiva han permitido la expansión del estudio de perfiles epigenómicos a nivel global. 
A continuación se describen las características de las principales técnicas utilizadas hasta el momento para el estudio del epigenoma.

\subsubsection{Inmunoprecipitación de la cromatina}

En 1988 se publicó un artículo en el que se demostraba la utilidad de la inmunoprecipitación de la cromatina (ChIP, de sus siglas en inglés Chromatin Immunoprecipitation) para el estudio de la familia de genes Hsp70 en Drosophila. A pesar de que existen diferentes versiones del protocolo original, los pasos básicos incluyen una fijación con formaldehído in vivo de las proteínas que se hallen unidas al DNA para después generar mediante sonicación una población de fragmentos de una longitud menor. Los fragmentos obtenidos tras la sonicación son inmunoprecipitados después con un anticuerpo específico para la proteína o modificación de histona de interés. Después de la inmunoprecipitación se purifica el DNA de los complejos anticuerpo-cromatina. De forma paralela, se purifica también un duplicado de la muestra tratada que no ha sido inmunoprecipitada. Ambas muestras son después analizadas mediante PCR cuantitativa de la zona de interés. De esta forma, la proporción de enriquecimiento mediante ChIP es determinada por una posición genómica específica. Dependiendo del anticuerpo, esta técnica permite identificar diferentes dianas genómicas de factores de transcripción asociados a la cromatina o modificaciones de las histonas. 


\subsubsection{ChIP-on-chip}

Si se combina la inmunoprecipitación de la cromatina (comentada en el apartado inmediatamente anterior) con una micromatriz (microarray) (ChIP-on-chip) o con una técnica de secuenciación masiva (ChIP-seq), en vez de analizar una región concreta se abre la posibilidad de estudiar una variante epigenética a nivel de todo el genoma.

Para cualquiera de estas dos aplicaciones, es necesario tener en cuenta varios aspectos. En primer lugar, para los estudios de ChIP-on-chip es necesario amplificar el material obtenido, bien mediante LM-PCR (de sus siglas en inglés Ligation Mediated PCR) (115), o mediante una amplificación linear con la polimerasa T7 (116). Otro aspecto a tener en cuenta es la plataforma que se desea utilizar. Actualmente se pueden encontrar en el mercado los de tres compañías diferentes: Affymetrix (California, EE. UU.), Agilent (California, EE. UU.) y Nimblegen (Islandia). La principal diferencia entre éstas se encuentra en la longitud, densidad y el espacio entre las sondas, distribuidas aleatoriamente por la superficie de la matriz (array).

\subsubsection{ChIP-seq}

En esta variante de la primera técnica descrita, tras realizar el ChIP se procede a una secuenciación masiva del material inmunoprecipitado. El número de lecturas realizadas de una región genómica específica es proporcional al enriquecimiento de dicha región. Hasta el momento esta técnica se ha llevado a cabo de forma exitosa usando diferentes aproximaciones a modificaciones de histonas $(117,118)$ 
o factores de transcripción $(119,120)$, usando la tecnología de secuenciación de Solexa (Illumina Inc, California, EE. UU. ). Esta técnica de secuenciación masiva se basa en la generación de agrupamientos (clusters) de aproximadamente 1000 fragmentos de DNA idénticos, cada uno de ellos generados a partir de una sola molécula de DNA. Esta reacción se lleva a cabo en una plataforma de cristal, que puede albergar hasta 50 millones de agrupamientos secuenciados de forma masiva y paralela.

\subsubsection{Metilación del DNA}

Cada vez está más claro que el silenciamiento génico a través de procesos de metilación de citosinas trae consigo numerosos eventos epigenéticos que cooperan para establecer un estado de represión de la expresión génica. Mientras que el significado de la metilación en los genes o en las regiones intergénicas no está del todo claro, la metilación en las regiones promotoras se asocia intensamente con el silenciamiento génico.

Se han descrito más de una veintena de técnicas para estudiar la metilación del DNA. Las diferencias básicas en estas técnicas se encuentran en aspectos como la resolución, la capacidad de obtener datos cuantitativos frente a cualitativos o el potencial para ser utilizadas de forma global, en vez de ofrecer datos a nivel local.

La mayoría de los estudios de metilación de citosinas se pueden dividir en tres grandes grupos (Ver Figura 8):

1. Aquellos que se basan en una modificación química del DNA mediante el tratamiento con bisulfito sódico. 
2. Basados en el uso de enzimas de restricción sensibles a la metilación

3. Métodos que se basan en la purificación del DNA metilado mediante técnicas de afinidad

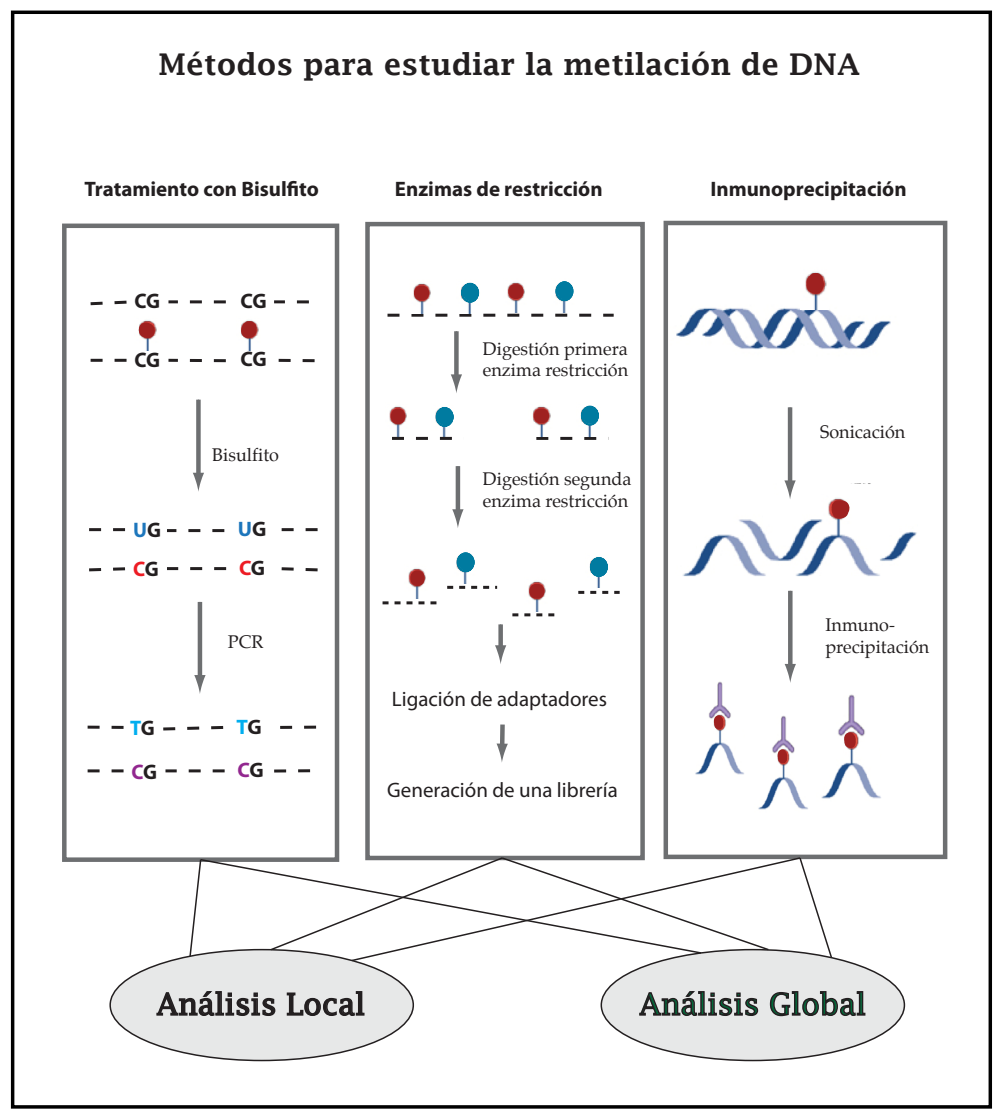

Figura 8. Representación de los tres métodos disponibles para el estudio de metilación de DNA

Los métodos basados en el tratamiento del DNA con bisulfito sódico presentan una resolución a nivel nucleotídico, pero no son útiles para estudios a nivel epigenómico, a pesar de que con el desarrollo de nuevas técnicas de secuenciación masiva parece que pronto será posible utilizarlos de forma rutinaria. Las demás aproximaciones permiten llevar a cabo estudios a nivel epigenómico, 
comprometiendo la sensibilidad de la técnica por la posibilidad de un estudio de metilación a nivel global.

\subsection{Bisulfito}

La secuenciación del DNA previo tratamiento con bisulfito sódico ofrece, como ya hemos comentado, la posibilidad de una resolución a nivel nucleotídico. Mientras que las citosinas metiladas no se ven afectadas por este tratamiento, las citosinas no metiladas sufren una desaminación que las convertirá en uracilos (Figura 9). Tras la PCR los uracilos se amplificarán como timinas, ofreciendo la posibilidad de comparar la secuencia amplificada tras el tratamiento con bisulfito y la secuencia sin tratar.

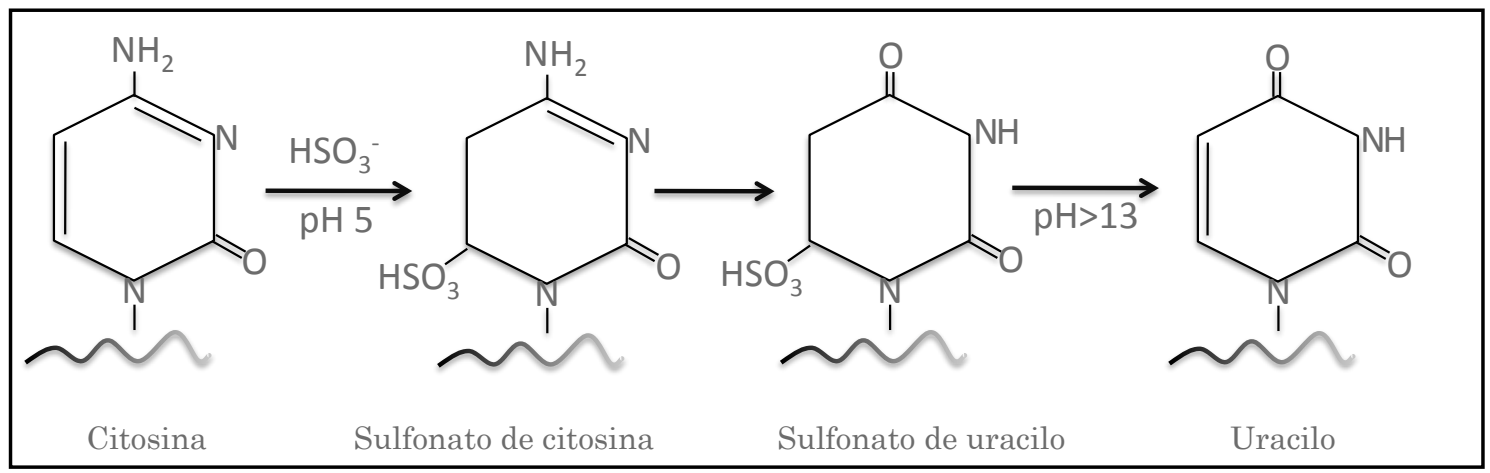

Figura 9 La reacción química con el bisulfto convierte las citosinas no metiladas en uracilos mediante una reacción de sulfonación, desaminación hidrolítica y por último desulfonación en medio alcalino.

Existen diversas técnicas para la cuantificación de los niveles de metilación. Quizá una de las más utilizadas y más laboriosas sea la de clonación y posterior secuenciación del fragmento amplificado. 
La pirosecuenciación (121) también ha sido adaptada a este tipo de estudios. En esta técnica la secuenciación del fragmento ocurre a medida que se va amplificando, mediante el uso de una señal luminiscente que se genera tras la incorporación del nucleótido en cuestión. Uno de los oligonucleótidos empleados está biotinilado, con el fin de conseguir que el DNA quede inmovilizado en bolas de estreptavidina, donde se secuencia en forma de ssDNA (DNA monocatenario). A pesar de que este método tiene la ventaja de que la cuantificación es relativamente fácil, está limitada a fragmentos de 25-30 pb, que no presenten más de una o dos posibles modificaciones.

En la PCR específica de metilación, MSP (de sus siglas en inglés MethylationSpecific PCR) (122), el DNA tratado con bisulfito se amplifica con pares de cebadores (primers) que funcionarán específicamente según la región de unión del oligonucleótido esté metilada o no. A pesar de que MSP es una técnica rápida y eficaz, hay que destacar que es una técnica cualitativa más que cuantitativa.

En COBRA (de sus siglas en inglés Combined Bisulphite Restriction Analysis) (123), el fragmento de interés es amplificado mediante PCR y después digerido con BstUI, incapaz de cortar cuando su sitio de restricción solapa con una citosina no metilada. El resultado de la digestión es posteriormente analizado mediante Southern Blot para calcular la ratio de fragmentos metilados/no metilados.

El MassArray es otra de las técnicas empleadas para el estudio de los niveles de metilación a nivel nucleotídico, que se basa en la espectrometría de masas MALDI/TOF para la cuantificación (124). Entre las ventajas de esta técnica se encuentran la necesidad de una cantidad relativamente pequeña de DNA y la 
rapidez de la misma, ya que es un método basado en la PCR. Sin embargo, y a diferencia de las técnicas descritas anteriormente, el elevado coste del equipo necesario la convierte en una técnica no demasiado extendida entre la comunidad científica.

\subsubsection{Uso de enzimas de restricción}

En la hibridación por diferencia de metilación (DMH, de sus siglas en inglés Differential Methylation Hybridization)(125), a los fragmentos generados tras la incubación con MseI se ligan unos adaptadores, que son después incubados con otra enzima de restricción, esta vez sensible a metilación (BstU1 o McrBC). El DNA no digerido es después amplificado mediante PCR e hibridado en micromatrices. La DMH puede detectar zonas con metilación diferencial de una muestra con respecto a otra de referencia.

El enriquecimiento de fragmentos digeridos por HpaII y posterior amplificación de los mismos mediante LM-PCR, HELP (de sus siglas en inglés Hpall tiny fragment Enrichment by Ligation mediated PCR) (126), implica la digestión en paralelo del DNA genómico de masa molecular elevada mediante MspI y su isoesquizómera HpaII. El resultado de cada digestión es amplificado y seleccionado de acuerdo con su tamaño mediante LM-PCR. Ambas poblaciones son después hibridadas en una matriz (array), diseñada especialmente para representar la posible población de fragmentos generados. El HELP assay permite hacer comparaciones tanto intra como intergenómicas y es semicuantitativo. Ya que será la técnica utilizada en este trabajo para interrogar el estado epigenómico entre las diferentes poblaciones, se encuentra detallada en la sección de Material y Métodos. 


\subsubsection{Purificación mediante afinidad}

Una de las formas más sencillas de enriquecimiento de la porción del DNA metilado en el genoma es la que se basa en separar los fragmentos metilados de los que no lo están, bien mediante columnas de purificación construidas con dominios MBD (Methyl Binding Domain), o bien mediante inmunoprecipitación con anticuerpos monoclonales que presenten afinidad hacia las citosinas metiladas.

El problema de estas técnicas en la práctica es que dependen de la densidad de citosinas metiladas en una región determinada. En general, los genomas de mamíferos presentan una densidad baja de CG, a excepción de aquellas zonas donde se concentran de forma elevada conocidas como Islas $\mathrm{CpG}$, en las cuales generalmente están sin metilar. Así, este tipo de técnica no es apropiada para cualquier tipo de estudios o de genoma (127).

\subsubsection{Nuevas tecnologías}

Las nuevas aproximaciones a la secuenciación masiva aportadas por Roche (Life Sciences, Roche Applied Science, Indianápolis, EE. UU.) 454 FLX o Illumina GA (Illumina Inc., California, EE. UU. ) aportan a las técnicas descritas anteriormente un aumento muy notable en la capacidad de resolución de las mismas. La secuenciación con 454 FLX de fragmentos de DNA tratados con bisulfito ya se ha llevado a cabo (128, 129), poniendo de manifiesto la enorme capacidad de la técnica. El primer epigenoma en ser secuenciado usando la tecnología de Illumina GA fue el de Arabidopsis thaliana (130), y resultó en una colección de datos que incluía 2,6 millones de secuencias únicas que cubría aproximadamente el 93\% de todas las 
CpG. Este estudio puso de manifiesto el aumento en la resolución en comparación con las matrices (arrays) utilizadas previamente y, aunque el epigenoma de plantas y animales presenta importantes diferencias, abrió el camino para futuros estudios (131).

La Illumina GA tiene un potencial mayor que la 454 FLX de Roche. Mientras que la primera es capaz de generar $\sim 40$ millones de lecturas de hasta 100 pares de bases, lo que asciende a más de mil millones de pares de bases secuenciadas, la segunda genera 400.000 lecturas de más de 250 pares de bases en un total de más de 100 millones de bases secuenciadas. A pesar de que si se compara el precio total de todo el proceso con lo que costaría hacerlo mediante secuenciación automática podría resultar barato, el caso es que estos métodos aún están al alcance de pocos laboratorios. Además, hay que tener en cuenta, una vez más, que una vez son generados los datos, la complejidad del análisis de los mismos es elevada. 


\subsection{Epigenética, Medio Ambiente Y Enfermedades}

\subsubsection{Hipótesis de la Higiene}

En 1989, un epidemiólogo inglés, David P. Strachan, propuso una teoría, coloquialmente conocida como Hipótesis de la Higiene, que ofrecía una posible explicación para el rápido incremento de las enfermedades alérgicas (132). Esta hipótesis especulaba con la posibilidad de que el tamaño familiar, la posición dentro de la misma y las infecciones sufridas durante la niñez, transmitidas por el contacto con hermanos mayores, podrían desempeñar un papel importante en el aumento de la prevalencia de las enfermedades alérgicas. La idea fue recibida en principio con cierto escepticismo, ya que entonces el pensamiento inmunológico dominante defendía la idea de que las infecciones predisponían al individuo a padecer enfermedades alérgicas (133). Pero a principios de los años 90 se describieron por primera vez dos poblaciones diferentes de linfocitos $\mathrm{T}$, Th1 y Th2 (134). Este descubrimiento cambió la perspectiva anterior, ya que se comprobó que, en animales de laboratorio, al inducir una respuesta Th1 frente a infecciones virales o bacterianas se favorecía la supresión de respuestas Th2, involucradas en la respuesta alérgica, y la hipótesis volvió a cobrar importancia.

Los mecanismos moleculares que subyacen en las enfermedades alérgicas y que intenta explicar la Hipótesis de la Higiene continúan siendo explorados (135-137), pero de lo que nadie duda es de que el marcado incremento de enfermedades alérgicas en la población podría ser un reflejo de cambios recientes entre el medio ambiente, en la manera de vivir y que los individuos genéticamente predispuestos sufrirían de forma más agresiva. Muchos estudios han intentado profundizar en las interacciones gen-ambiente que favorecen el desarrollo, aumentan la gravedad 
o limitan una evolución positiva de la inflamación alérgica $(1,138)$. Ya se dispone de pruebas de que la exposición a un mismo producto microbiano puede ejercer efectos opuestos en un individuo propenso a desarrollar una respuesta alérgica, según su genotipo, con lo que el estudio de las enfermedades alérgicas adquiere un nuevo escalón de complejidad(1).

\subsubsection{Orígenes de la Salud y la Enfermedad durante el Desarrollo (Developmental Origins of Health and Disease)}

En 1992 una nueva hipótesis, conocida como "La Hipótesis de Baker", "Early Origins of Adult Diseases" o también llamada "Developmental Origins of Health and Disease" $(139,140)$, sugería que diferentes exposiciones ambientales durante el período intrauterino podían alterar la programación en el desarrollo de determinados órganos, lo que podría determinar diferentes adaptaciones fisiológicas y metabólicas durante la vida adulta. De este modo, se sugería un posible efecto combinado del medio ambiente y los factores genéticos, desempeñando, de forma conjunta, un importante papel en la predisposición que un individuo tiene a la hora de padecer una determinada enfermedad.

Los estudios epidemiológicos han puesto en evidencia que determinados factores ambientales que se producen durante la vida intrauterina o a temprana edad, pueden influenciar la aparición posterior de determinadas enfermedades crónicas como el cáncer, las enfermedades cardiovasculares, la diabetes, la obesidad o incluso trastornos del comportamiento como la esquizofrenia (141-143).

Uno de los mecanismos generales por el que las exposiciones prenatales o postnatales podrían alterar el fenotipo durante etapas posteriores de la vida 
podrían ser las modificaciones en los patrones epigenéticos. El hecho de que, en las células somáticas, los cambios epigenéticos puedan ser transmitidos durante las divisiones mitóticas, proporciona un posible mecanismo por el cual los efectos ambientales sobre el epigenoma podrían tener repercusiones en la expresión génica a largo plazo (144).

En este sentido, cada vez más estudios en modelos animales demuestran que diferentes estímulos ambientales que se producen durante las primeras etapas de la vida, entre los que se incluyen los suplementos nutricionales $(145,146)$, xenobióticos (147), problemas conductuales (148), pequeñas dosis de radiación (149) o el humo del tabaco (150) pueden tener un tremendo impacto en la programación epigenética, y por tanto, en el posterior desarrollo de enfermedades.

\subsubsection{Epigenética y Regulación de la Respuesta Inmune}

Como ya se ha comentado, en las enfermedades alérgicas el balance Th1/Th2 se encuentra desviado, presentando una respuesta de tipo Th2 exagerada frente a sustancias que en condiciones normales son inocuas. En el genoma humano, los genes que codifican las interleucinas 4, 5 y 13, características de la reacción alérgicas, se encuentran en la misma región cromosómica (5q31.1), como se muestra en la Figura 10 (151). La expresión de estas citocinas está acompañada por un aumento en la transcripción de GATA3 y un proceso de remodelación de la cromatina hacia un estado fisiológicamente 'abierto' que permitirá la transcripción de estos genes (152). 


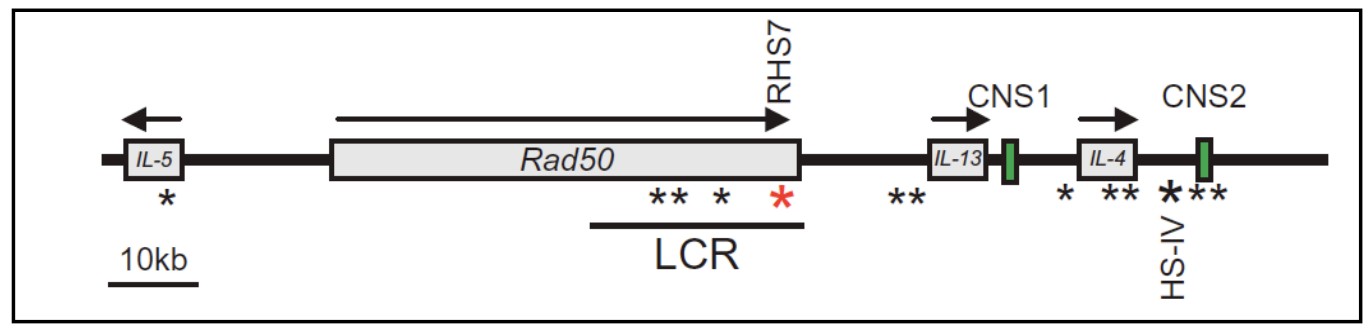

Figura 10. Representación esquemática del locus de las citocinas Th2. Las flechas indican la direccionalidad de la transcripción para cada gen. Los asteriscos negros representan sitios de hipersensibilidad a DNasaI (HS). Con un asterisco rojo se representa RHS7 y con un asterisco negro de mayor tamaño se representa la zona de HS IV. Los rectángulos en verde simbolizan zonas no codificantes altamente conservadas (CNS1 y CNS2). El locus que controla la región (LCR) aparece subrayado. Modificado de van Panhyus (151)

La expresión de GATA3 es esencial para la diferenciación linfocitaria hacia Th2, siendo indispensable para la producción de IL-5 e IL-13, pero no de IL-4 (153). La familia de STAT5 (Signal Transducer and activator of transcription 5A) está compuesta por dos miembros, STAT5a y STAT5b, críticos para la proliferación y supervivencia de linfocitos $\mathrm{T}(154,155)$. Los sitios de unión de GATA-3 se encuentran en la zona promotora de IL-5 e IL-13, indicativo de la actividad como factor de transcripción de GATA-3 (156). En las células Th2 en las que se anula la expresión de GATA-3 queda de igual forma inhibida la expresión de IL-3 e IL-5 (153).

Los procesos de remodelación de cromatina se demostraron mediante digestiones con DNasaI. En los loci silenciados transcripcionalmente, el DNA se encuentra altamente condensado alrededor de las histonas, en forma de heterocromatina. En este estado, el DNA es resistente a la digestión con DNasaI, mientras que cuando se encuentra en un estado transcripcionalmente activo (eucromatina) es susceptible a esta digestión. Así, se han definido diferentes loci en la región 5q31.1 que son susceptibles o no al tratamiento con DNasaI según se trate de células Th1 o Th2 
(151). Entre estos loci se encuentra la secuencia conservada no codificante 1 (NCS1, de sus siglas en inglés Non Coding Sequences), situada en una zona intergénica entre $I L-4$ e $I L-13$ (157), HS-II en el segundo intrón de $I L-4$ y HS-V en la región promotora del mismo (158). El HS-IV es accesible tanto en las células Th1 como en las Th2, lo que sugiere un mecanismo de silenciamiento en Th1 (159). De particular importancia es RHS7, que se encuentra accesible a la digestión con DNasaI al principio del proceso de diferenciación hacia Th2 (160).

Además de estos cambios en la conformación de la cromatina, se han descrito también cambios en la metilación del locus de la $I L-4$, que se presenta hipermetilado en células Th1 y pierde esta marca en células Th2 (161).

GATA-3 podría estar implicado en la remodelación de la cromatina en el locus IL4/IL13, induciendo los sitios sensibles a la DNasa I $(162,163)$ y en la regulación de los procesos de metilación en esta zona. Además, la trimetilación en la lisina 4 de la histona 3 (H3K4me3), propia de sitios transcripcionalmente activos, se encuentra presente en el locus IL4/IL13 de las células Th2 (164), mientras que la trimetilación en la lisina 27 de la histona 3 (H3K27me3), presente en zonas silenciadas transcripcionalmente, se encuentra en este mismo locus en las células Th1 (165).

\subsubsection{Alergia, Epigenetica y Factores Ambientales}

La respuesta alérgica se caracteriza por una inflamación sistémica derivada de una respuesta desproporcionada de tipo Th2 que cursa con un aumento en la expresión de las IL 4, 5, 9 y 13, así como, en general, un aumento en los niveles en 
plasma de IgE. Genéticamente, las enfermedades alérgicas se definen como poligénicas, ya que se han descrito una gran cantidad de genes involucrados, genéticamente heterogéneas, puesto que diferentes combinaciones de genes candidatos se relacionan con el desarrollo de enfermedades alérgicas y pleiotrópicas, ya que un mismo gen puede afectar a más de una característica fenotípica.

La introducción de la epigenética en el marco de las enfermedades alérgicas ha abierto un nuevo campo de estudio, con lo que se podrían ver resueltas cuestiones como las diferencias fenotípicas entre hermanos monocigóticos, la edad de aparición de la enfermedad y la gravedad de la misma, la mayor incidencia de esta enfermedad en mujeres que en hombres o el hecho de que en el caso de que la madre sea alérgica las posibilidades de que la descendencia también lo sea sean mayores que en el caso de que sea el padre el que padezca la enfermedad alérgica (166).

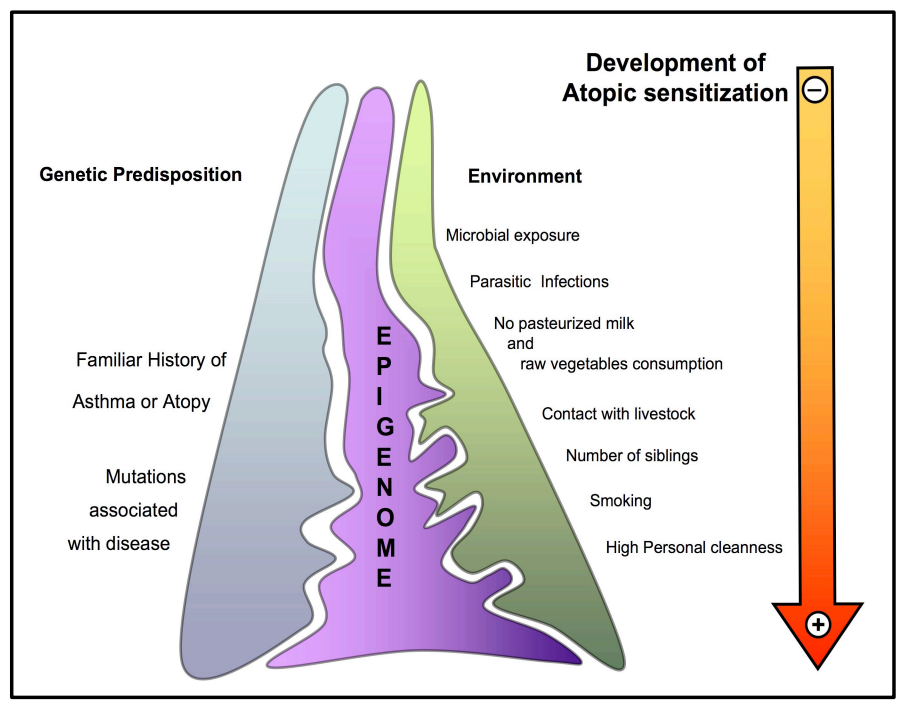

Figura 11. Interacción entre la predisposición genética individual y las exposiciones ambientales mediante alteraciones en el epigenoma y posterior desarrollo de enfermedades atópicas. (Pascual y cols 2010, en prensa) 
Se ha propuesto que, para considerar las modificaciones epigenéticas como un candidato real que influya en la etiología de enfermedades complejas, debería de cumplir, al menos tres características $(167,168)$ :

1. Tienen que influenciar el fenotipo: los gemelos monocigóticos comparten la misma información genética, pero presentan una discordancia en la prevalencia de las enfermedades alérgicas que alcanza el 25\% de los casos. En este sentido, las modificaciones epigenéticas podrían explicar estas diferencias, así como las diferencias de prevalencia entre sexos, la edad de desarrollo de la enfermedad o la gravedad de la misma (55) .

2. Tienen que ser heredables: se ha demostrado que las modificaciones epigenéticas se transmiten a la descendencia (169). En los cultivos celulares de células $\mathrm{T}$ los patrones epigenéticos se mantienen durante 20 divisiones en ausencia de estímulos externos. Esto es de particular importancia cuando se plantean cuestiones como la memoria inmunológica.

3. Tienen que responder de forma dinámica a las variables ambientales: se sabe que las modificaciones en los patrones epigenéticos ocurren con más frecuencia que las posibles modificaciones que pueden ocurrir en la secuencia de pares de bases del DNA (167).

Durante los últimos años, diferentes trabajos han intentado dilucidar la posible conexión entre distintas exposiciones ambientales, enfermedades atópicas y epigenética. 


\subsubsection{Dieta, Epigenética y Enfermedades Alérgicas}

La dieta moderna, presente en la mayoría de los países occidentalizados, se aleja bastante de la dieta de generaciones anteriores en los mismos países. La dieta contemporánea se basa en alimentos que han sido procesados, modificados, almacenados y en ocasiones, transportados largas distancias. Además, se consumen menos vegetales, y el contenido nutricional de éstos también ha bajado (170). Esta tendencia ha dado lugar a la hipótesis de que estos cambios recientes en la dieta puedan estar relacionados con el aumento en la prevalencia de las enfermedades alérgicas (54).

Hollingsworth et al (171) basan su trabajo en la hipótesis de que posibles cambios en la dieta pueden ejercen un efecto en el desarrollo ulterior de enfermedades alérgicas. Se ha demostrado que la ingesta adecuada de ácido fólico es esencial para la correcta formación del tubo neural del bebé, lo que previene además posibles malformaciones congénitas (172). Este suplemento a la dieta supone una fuente de donadores de grupo metilo y se ha demostrado que, al mismo tiempo, puede causar cambios en la metilación de DNA y, por tanto, afectar a la expresión génica normal (173).

Debido a que en los países desarrollados muchas mujeres embarazadas suplementan su dieta con ácido fólico, los autores de este estudio (171) se plantean la posibilidad de que, además de proteger al feto de futuras complicaciones, también se estén incrementando las posibilidades de desarrollar asma en un futuro. 
En este trabajo se estudiaron los niveles de metilación en ratones (C57BL/6J) a nivel global en tejido pulmonar de cuatro animales, dos sometidos intra utero a dietas ricas en folatos y dos que recibieron dosis bajas durante el mismo período. Los autores emplearon para ello el MSDK (de sus siglas en inglés Methylation Sensitive Digital Karyotyping) y describieron cinco genes (Runx3, Nfatc1, Jak2, Rcor3 y Ube2j1) que presentan diferente estado de metilación y expresión entre ambos grupos.

Los autores presentan datos de que la administración de dietas ricas en folato durante los periodos de lactancia o madurez parecen no afectar significativamente el desarrollo y la gravedad de enfermedades respiratorias. Sin embargo, no ocurre lo mismo durante la gestación, en la que parece existir un período de vulnerabilidad durante el cual, las dietas ricas en folato podrían tener un impacto en la de metilación de citosinas y en la predisposición a enfermedades alérgicas.

\subsubsection{Exposición a hidrocarbonos aromáticos policíclicos, Epigenética y Enfermedades Alérgicas}

Perera y cols (174), se basan en datos previos (175) en los que se señala que las exposiciones durante la vida intrauterina a hidrocarbonos aromáticos policíclicos (PAH, de sus siglas en inglés polycyclic aromatic hydrocarbons), podrían constituir un factor de riesgo a la hora de explicar el desarrollo de enfermedades asmáticas en niños de corta edad, para realizar un estudio sobre la exposición a estos compuestos derivados principalmente del tráfico urbano, durante la vida uterina. Queda pendiente para posteriores estudios determinar si las exposiciones 
repetidas a estos compuestos durante la infancia también tienen efecto en la predisposición y desarrollo de estas enfermedades.

La población de estudio empezó con 20 madres no fumadoras hispanas y afroamericanas a las que se les monitorizó de forma periódica durante el embarazo. Tras la extracción de células T del cordón umbilical, se estudiaron los patrones de metilación global mediante MSRF (de sus siglas en inglés Methylation Sensitive Restriction Fingerprint) $(125,176)$. Los autores describieron que los cambios en la metilación de la región promotora del gen ASCL3 (Acyl-CoA synthetasa long-chain family member 3), se asociaban significativamente con la exposición materna a los $\mathrm{PAH}$, así como a síntomas de asma antes de la edad de cinco años.

El estudio, que comenzó con la exploración de 20 muestras, se extendió, una vez encontrado el gen candidato, a 56. La información sobre los niveles de metilación, obtenidos mediante MSPCR (de sus siglas en inglés Methyl Sensitive PCR) mostraron una asociación positiva entre el nivel de exposición a estos compuestos y el de metilación, a pesar de que los autores no encontraron una relación evidente entre los niveles de metilación y el desarrollo de asma.

\subsubsection{Vida en ambientes rurales, Epigenética y Enfermedades Alérgicas}

Algunos estudios epidemiológicos señalan el efecto protector que la vida en un ambiente rural durante la niñez ofrece frente a las enfermedades alérgicas (177, 178). La base sería que el desarrollo durante las primeras etapas de la infancia 
entre establos y graneros, en contacto con animales y consumiendo leche sin pasteurizar conlleva un contacto directo con una gran variedad de agentes microbianos, que potenciarían una respuesta Th1 frente a una respuesta alérgica Th2.

En un reciente estudio, Shaub y cols. (179) se propusieron comprobar si este efecto protector del ambiente rural ocurría in utero, para lo que seleccionaron 82 madres (22 que vivían en ambientes rurales y 60 en urbanos) sanas, sin complicaciones durante el embarazo, de las que recogieron células mononucleares del cordón umbilical tras el parto. Del total celular, los autores seleccionaron las células T reguladoras (Treg), debido a la importante función que estas células ejercen durante la maduración y polarización de las diferentes poblaciones de células T.

Tras la estimulación de las células con diferentes combinaciones antigénicas (peptidoglicano, PHA y Dermatophagoides pteronyssinus) durante tres días, los autores analizaron la metilación de FOXP3 mediante RT-PCR, sin encontrar diferencias significativas en los niveles de metilación entre ambos grupos. Sin embargo, describieron un mayor número de células Treg asociado a una disminución en la respuesta Th2 en las muestras obtenidas de madres que vivían en ambientes rurales, cuando fueron comparadas con las células obtenidas de madres de zonas urbanas.

\subsubsection{Tabaquismo, Epigenética y Enfermedades Alérgicas}

Se sabe que la exposición continua al humo del tabaco es la mayor causa de la inflamación crónica irreversible en los pulmones, lo que conlleva una limitación en 
la capacidad respiratoria, una de las principales características de la enfermedad crónica obstructiva del pulmón $(C O P D$, EPOC en español, de sus siglas en inglés chronic obstructive pulmonary disease)(180)

El recuento de macrófagos de estos pacientes crece de forma concomitante con la gravedad de la enfermedad, siendo la cantidad de citocinas proinflamatorias secretadas por estas células mayor en los casos en los que el paciente es o ha sido fumador (181). Se sabe que la actividad de las histonas desacetilasas disminuye tras el tratamiento con extractos de humo de tabaco y se ha comprobado en los macrófagos que, tras este tratamiento, la HDAC1, HDAC2 y HDAC3 disminuyen, además de su actividad, su concentración celular (182). Otra observación parecida se ha realizado en pulmones de ratas, en la que se observa una respuesta inflamatoria aguda después de la exposición al humo de tabaco (183). Tomando en conjunto estas observaciones, no es de extrañar que, debido a la gran importancia de estas enzimas en el equilibrio epigenético, cualquier perturbación en su actividad tenga consecuencias en la expresión de algunas de las más importantes citocinas proinflamatorias.

En modelos animales múridos, tanto el tabaquismo activo como el pasivo han demostrado predisponer a una sensibilización alérgica. Un posible mecanismo propuesto para explicar este hecho, como ya ha sido sugerido con anterioridad para otras sustancias nocivas (184), es que los extractos del humo del tabaco podrían aumentar la presentación antigénica, bien mediante mecanismos de adsorción al alérgeno, bien mediante modificaciones estructurales del alérgeno mismo (185). 
Además, diversos estudios han demostrado que la exposición al humo de tabaco puede alterar la expresión génica, promoviendo la hipermetilación de determinados promotores, que normalmente se expresan en pulmones de individuos sanos $(186,187)$. A este dato se le añade no sólo el hecho de que la madre haya sido fumadora durante el embarazo, sino el de que la abuela haya sido fumadora durante el embarazo de la madre, también puede tener influencia en el posterior desarrollo de asma por parte de generaciones futuras (188). Este mecanismo sugiere que las alteraciones epigenéticas mediadas por la exposición al humo del tabaco pueden tener repercusiones en la predisposición a sufrir enfermedades alérgicas no sólo en el propio individuo, sino también en las generaciones venideras. 
2 Hipótesis de trabajo 
El asma y la alergia son enfermedades de herencia compleja cuya frecuencia se ha incrementado notablemente en las últimas décadas. Por otro lado, la exposición a determinados factores ambientales puede también ejercer influencia en su desarrollo.

Las alteraciones en el epigenoma, entre las que se encuentra la metilación de citosinas, presentan una relación directa con el desarrollo de algunas enfermedades complejas y, en su mayoría, se producen como respuesta a agresiones del ambiente. De este modo, la plasticidad de las modificaciones epigenéticas podría constituir el nexo de unión entre los factores genéticos y ambientales en este tipo de enfermedades.

Tomando estas observaciones de forma conjunta nuestra hipótesis de trabajo se basa en la posibilidad de que determinadas alteraciones en los patrones epigenéticos puedan desempeñar un papel en la etiopatogenia del asma alérgica 
3 Objetivos 
Los objetivos concretos de este estudio son:

1. Estudiar el patrón epigenético, en términos de metilación de citosinas, en los linfocitos B de pacientes con asma alérgica e individuos sanos de una forma global, describiendo todo el epigenoma. Se compararán ambos patrones epigenéticos, tratando de identificar una posible correlación entre las alteraciones epigenéticas y la enfermedad alérgica.

2. Identificar, en el caso de que sea posible, loci que presenten patrones de metilación diferencial en los linfocitos $\mathrm{B}$ de los pacientes alérgicos respecto a los individuos del grupo control.

3. Analizar posibles discrepancias en los niveles de expresión de los genes que presenten patrones de metilación diferencial entre los individuos alérgicos y los individuos sanos.

4. Correlacionar el estado de metilación de los genes que presenten metilación diferencial con los niveles de expresión de los mismos para identificar la presencia de posibles marcadores epigenéticos de la enfermedad. 
4 Material y Métodos 


\subsection{Selección de la población de estudio}

En este estudio se recogieron muestras de 40 individuos, 20 pacientes y 20 controles procedentes del Servicio de Inmunoalergia del Hospital Universitario de Salamanca. Las muestras fueron obtenidas previo consentimiento informado, siguiendo las normas legales para Estudios Clínicos en España y las del Comité de Ética del Hospital.

La historia clínica fue elaborada por los facultativos del Servicio de Inmunoalergia del Hospital Universitario de Salamanca. Entre los datos demográficos que se recogieron de la misma se encuentran la edad y el sexo. También se evaluaron los antecedentes familiares de atopia y/o asma. Entre las variables clínicas que se consideraron en el estudio se encuentran la presencia de asma, así como el tipo y el grado de asma, la presencia de atopia, las pruebas cutáneas con una batería estándar de aeroalérgenos, los valores de IgE total y, cuando procedía, de IgE específica, la intolerancia o no a los antiinflamatorios no esteroideos (AINE) y la existencia o no de poliposis.

\subsubsection{Diagnóstico de Asma}

El diagnóstico de asma fue realizado por los facultativos del Servicio siguiendo los siguientes criterios:

a) Al menos dos síntomas consistentes con la patología asmática, entre los que se incluyen tos, disnea opresión torácica o percepción de sibilancias 
b) Hiperreactividad bronquial, bien definida mediante una prueba positiva de metacolina o con una prueba de broncodilatación positiva (mejoría del FEV1 superior al $12 \%$ y más de $200 \mathrm{~mL}$ )

c) Ausencia de otras enfermedades respiratorias

La función pulmonar se determinó mediante espirometría, siguiendo los criterios de la ATS (American Thoracic Society)(189)

La gravedad del asma se clasificó según los criterios de la GINA (4), en los siguientes grupos:

\section{Asma intermitente:}

Aparición de los síntomas con una frecuencia inferior a dos veces por semana

Crisis de corta duración

Síntomas nocturnos con una frecuencia inferior a dos veces mensuales

FEV1 superior al 80\% del valor teórico y variabilidad del PEF inferior al $20 \%$

\section{Asma Persistente Leve}

Frecuencia de los episodios superior a dos veces por semana, pero sin síntomas diarios

Episodios nocturnos que se presentan más de dos veces al mes, pero menos de una vez por semana

FEV1 superior al 80\% del valor teórico y variabilidad del PEF entre el 20$30 \%$ 


\section{Asma Persistente Moderada}

Síntomas diarios

Los síntomas afectan a la actividad diaria y al sueño del paciente

Síntomas nocturnos al menos una vez por semana

FEV1 entre el 60-80\% del valor teórico y variabilidad del PEF superior al $30 \%$

\section{Asma persistente grave}

Síntomas diarios

Crisis frecuentes

Episodios asmáticos nocturnos frecuentes

$\mathrm{FEV}_{1} \leq 60 \%$ del predicho y variabilidad del PEF superior al $30 \%$

Aquellos pacientes que en el momento de la consulta estaban bajo tratamiento para controlar su sintomatología asmática, fueron diagnosticados siguiendo las recomendaciones de la GINA, atendiendo al tratamiento que recibían en ese momento.

\subsubsection{Diagnóstico de Alergia}

El diagnóstico de alergia se consideró positivo cuando las pruebas cutáneas resultaron positivas al menos frente a uno de los alérgenos probados. Esta prueba se realizó siguiendo las recomendaciones para la normalización de alérgenos y pruebas cutáneas de la EAACI (The European Academy of Allergy and Clinical Immunology) (190) 
La respuesta cutánea inmediata frente a extractos alergénicos, caracterizada por la presencia de pápula y eritema en el lugar de la prueba se obtuvo a los 15 minutos para la histamina y entre 15-20 minutos para los alérgenos. Las pruebas se consideraron positivas cuando en la reacción frente al antígeno aparecía una pápula con un diámetro mayor o igual $3 \mathrm{~mm}$, siempre que el control negativo no indujera pápula.

La batería estándar de aeroalérgenos comunes incluía los siguientes: ácaros del polvo (Dermatophagoides pteronyssinus, D. farinae, Lepidoglyphus destructor, Tyrophagus putrescentiae, Euroglyphus maynei, Acarus siro), cucaracha (Blatella germanica), esporas de hongos (Alternaria alternata, Clodosporium herbarum, Penicillium notatum, Aspergillus fumigatus), epitelios de animales (perro, gato, hámster, caballo y conejo) y pólenes (Parietaria judaica, Chenopodium Album, Artemisa Vulgaris, Plantago lanceolata, Olea europaea, Phleum pratense, Cynodon dactilys) (ALK-Abelló, Madrid, España). Como control positivo se empleó una solución de histamina $10 \mathrm{mg} / \mathrm{mL}$ y como control negativo solución salina (ALK-Abelló, Madrid, España). Antes de empezar la prueba se retiraron los antihistamínicos u otros fármacos que pudieran afectar la lectura, siguiendo las indicaciones de la EAACI (190)

\subsubsection{Determinación de IgE}

La cuantificación de esta inmunoglobulina en suero constituye hoy en día una técnica de rutina en el diagnóstico alergológico. Los niveles de IgE fueron determinados en todas las muestras de suero, tanto de pacientes como de controles, mediante fluoroenzimoinmunoanálisis (Pharmacia Cap System, Pharmacia, Uppsala, Suecia), siguiendo las recomendaciones del fabricante. 
En los casos en los que fue necesario, se realizó una determinación de $\operatorname{IgE}$ específica también mediante fluoroenzimoinmunoanálisis (Pharmacia Cap System, Pharmacia, Uppsala, Suecia)

\subsubsection{Controles}

Los criterios para la inclusión de sujetos como controles en este estudio fueron los siguientes:

Ausencia de síntomas o historia clínica de asma

Ausencia de síntomas o historia clínica de otras enfermedades pulmonares

Ausencia de síntomas o historia clínica de atopia

Ausencia de síntomas o historia clínica de poliposis nasal

Pruebas cutáneas negativas para la batería de aeroalérgenos probados

Ausencia de familiares de primer grado con historia de asma

Ausencia de familiares de primer grado con historia de atopia

IgE total inferior a $100 \mathrm{kU} / \mathrm{L}$

\subsubsection{Pacientes}

Los individuos incluidos como casos en este estudio debían reunir las siguientes condiciones:

Presencia de asma moderada o grave

Presencia de pruebas cutáneas positivas al menos para uno de los ácaros testados

IgE específica positiva para alguno de los ácaros probados (coincidente con la prueba cutánea) 


\subsubsection{Obtención de linfocitos mediante gradiente de densidad}

La extracción de sangre periférica se realizó mediante una venopunción antecubital. Todas las muestras de sangre periférica fueron recogidas en contenedores con EDTA para evitar la coagulación. En todos los casos, el aislamiento de los linfocitos B se llevó a cabo de forma inmediata tras la recepción de la muestra.

La fracción linfática se obtuvo mediante centrifugación por gradiente de densidad con Ficoll (Ficoll-Paque PLUS, densidad: $1.077 \mathrm{~kg} / \mathrm{l}$, GE Healthcare Bio-Sciences AB, Uppsala, Suecua). La sangre total fue diluida 1:1 con medio de cultivo RPMI Medium 1640 (Invitrogen, Carlsbad, California, EE. UU.) y la centrifugación se realizó a 1600 rpm durante aproximadamente 30 minutos en una centrífuga sin freno a temperatura ambiente.

Debido a que los eritrocitos y granulocitos tienen una densidad superior a la de las células mononucleares a la presión osmótica característica del Ficoll, las primeras sedimentan antes que las segundas, que se encuentran

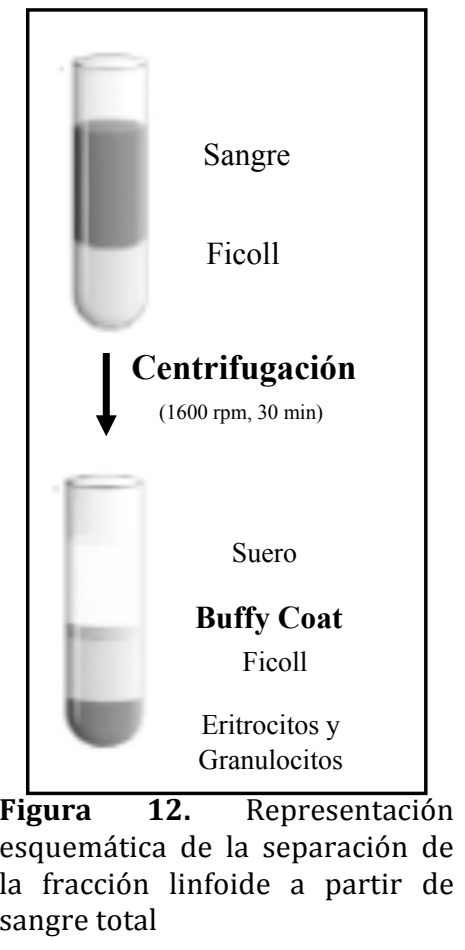


formando una capa intermedia entre el Ficoll y el plasma. Tras esta centrifugación, se recogió la fracción de interés y se procedió al recuento celular en una cámara de Neubauer (Figura 12).

\subsubsection{Obtención de células CD19 mediante selección inmunomagnética}

La selección de células $\mathrm{CD} 19^{+}$se realizó a partir de la fracción leucocitaria obtenida tras la centrifugación en gradiente de densidad. La selección positiva de los linfocitos B se llevó a cabo mediante Dynabeads® CD19 (Pan B) (Dynal Biotech ASA, Oslo, Noruega) según las recomendaciones del fabricante. La cantidad de Dynabeads necesaria se calculó para cada caso según el recuento en cámara de Neubauer realizado previamente. Se utilizaron al menos $25 \mu \mathrm{L}$ por cada $5 \times 10^{9}$ células. La fracción linfocitaria se incubó con los dynabeads durante 30 minutos con una rotación suave y a $4^{0} \mathrm{C}$ para eliminar la actividad fagocitaria y otros posibles procesos metabólicos. Tras el periodo de incubación, los tubos se colocaron en el MPC®-S (de sus siglas en inglés Magnetic Particle Concentrator for Microcentrifuge Tubes) (Dynal Biotech ASA, Oslo, Noruega). El concentrado celular se lavó dos veces con RPMI Medium 1640 (Invitrogen,Carlsbad, California, EE. UU.).

Una vez aisladas las células, aproximadamente las tres cuartas partes del total se utilizaron para la extracción de DNA y RNA, reservando una pequeña cantidad con el fin de llevar a cabo experimentos de citometría de flujo y comprobar la pureza del proceso. 


\subsubsection{Citometría de flujo}

Con el fin de comprobar la pureza del proceso de selección inmunomagnética se llevaron a cabo pruebas de citometría de flujo, en las que se analizaron las características típicas de tamaño y granularidad (FSC/SSC) y el patrón de expresión de marcadores específicos de células T (CD3) o células B (CD45 y CD20) de cada muestra (Becton Dickinson Bioscience. San José, California, EE. UU.). Una vez obtenidos los linfocitos $\mathrm{CD} 19^{+}$de la fracción linfocitaria, según el protocolo descrito en la sección anterior, las células se incubaron con anticuerpos fluorescentes CD3-FITC, CD45-APC y CD20-PE (Becton Dickinson Bioscience. San José, California, EE. UU.) durante 15 minutos a temperatura ambiente y en ausencia de luz. A continuación se centrifugaron durante 5 minutos a 2000 rpm en PBS para eliminar el exceso de anticuerpo libre, y se resuspendieron en $0,5 \mathrm{~mL}$ de PBS. La adquisición en el citómetro de flujo se llevo a cabo de forma inmediata y se comprobó que cada muestra estaba significativamente enriquecida $(\geq 80 \%)$ en linfocitos B CD3-CD45+CD20+.

El citómetro empleado en este estudio fue un modelo FACScalibur (Becton Dickinson Bioscience. San José, California, EE. UU.), utilizando el programa informático CellQuest ${ }^{\circledR}$ (Becton Dickinson Bioscience. San Jose, California, EE. UU.) y, para el análisis, los programas informáticos PAINT-A-GATE-PROTM y CellQuest ${ }^{\circledR}$ (Becton Dickinson Bioscience. San José, California, EE. UU.)

\subsubsection{Envío de las muestras}

El envío de las muestras se realizó en hielo seco dentro de un periodo máximo de 72 horas, a través de una empresa especializada en este tipo de envíos (@World Courier Management Inc.) Inmediatamente después de la recepción de las muestras se 
procedió a su almacenamiento a $-20^{\circ} \mathrm{C}$ ó $-80^{\circ} \mathrm{C}$ hasta su uso, con el fin de evitar procesos de degradación.

\subsubsection{Purificación del DNA}

La calidad y pureza del DNA empleado en este trabajo fue en todo momento un factor importante y limitante, ya que puede comprometer el éxito en experimentos posteriores. A pesar de que cualquier método de extracción y purificación de DNA es válido, en los casos en los que la cantidad de DNA no fue un factor limitante se llevó a cabo una purificación de DNA mediante diálisis, con el fin de asegurar la utilización de DNA genómico de masa molecular elevada

El protocolo que se detalla a continuación se llevó a cabo en el laboratorio del Dr. Greally, en el Albert Einstein College of Medicine, sito en Nueva York, Estados Unidos. En este protocolo, que tiene una duración aproximada de tres días, el DNA se trató previamente con proteinasa K y RNasa A para después proceder a lavar el DNA con fenol saturado y cloroformo. Con el fin de eliminar posibles trazas de EDTA, se realizó una diálisis del DNA durante aproximadamente 24 horas con un tampón 0,2X de SSC (cloruro sódico y citrato sódico) pH7. Tras este período, para aumentar la concentración de la muestra y eliminar el exceso de líquido, se cubrió cada bolsa de diálisis con polietilenglicol (PEG). El DNA obtenido tras este proceso se almacenó de forma sistemática a $4^{\circ} \mathrm{C}$ hasta su posterior uso.

\subsubsection{Preparación de las bolsas de diálisis}

La membrana que se empleó para llevar a cabo la diálisis fue de $32 \mathrm{~mm}$ (Fisher Scientific, Waltham, Massachussets, EE. UU.). El tamaño de las membranas de diálisis 
depende del volumen de la muestra a tratar. En este caso, la longitud de las membranas fue de aproximadamente 6 centímetros cada una. Con el fin de aclarar y humedecer las membranas, éstas se depositaron en agua destilada durante al menos 30 minutos, evitando que las membranas se pegaran entre sí, ya que podrían romperse al tratar de despegarlas.

Durante este tiempo, se preparó la solución de tratamiento como se detalla en la tabla 3, llevándola, una vez preparada, a un baño de $60^{\circ} \mathrm{C}$.

Tabla 3. Reactivos, cantidad y concentración final de los mismos para un volumen total de 3L del tampón de tratamiento empleado en el acondicionamiento de las bolsas de diálisis.

\begin{tabular}{|c|c|c|c|}
\hline Reactivo & Cantidad & Concentración Final & Objetivo \\
\hline $\mathrm{NaHCO}_{3}$ & $60 \mathrm{~g}$ & $2 \%$ & Favorece la apertura de los poros \\
\hline $1 \mathrm{M} \mathrm{EDTA}(\mathrm{pH} 8)$ & $3 \mathrm{~mL}$ & $1 \mathrm{mM}$ & Quelante de metales pesados \\
\hline $\mathrm{H}_{2} \mathrm{O}$ & $2997 \mathrm{~mL}$ & $\begin{array}{c}\text { Llevar la solución al volumen } \\
\text { adecuado }\end{array}$ \\
\hline Volumen Total & $3 \mathrm{~L}$ & \multicolumn{2}{|c}{} \\
\hline
\end{tabular}

Una vez que la solución de tratamiento estuvo preparada, se transfirieron las membranas previamente hidratadas a esta solución y se incubaron durante al menos 30 minutos a $60^{\circ} \mathrm{C}$. Para terminar el proceso de tratamiento, se lavaron las membranas al menos 3 veces con agua bidestilada $\left(\mathrm{ddH}_{2} \mathrm{O}\right)$.

Los tubos de diálisis pueden utilizarse inmediatamente o pueden almacenarse a $4^{0} \mathrm{C}$ en una solución al 50\% de etanol. Bajo estas condiciones, y asumiendo que las membranas no se secan, pueden durar varios meses. En los casos en los que se 
utilizaron membranas que habían sido preparadas con anterioridad, se las sometió a un lavado de al menos una hora con $\mathrm{ddH}_{2} \mathrm{O}$.

\subsubsection{Purificación del DNA}

El volumen de cada muestra fue en todos los casos de al menos $500 \mu \mathrm{L}$. Se preparó una solución de lisis de acuerdo al volumen de cada muestra en particular. En la tabla 4 se muestran las concentraciones relativas para $10 \mathrm{~mL}$ de solución amortiguadora:

Tabla 4. Reactivos, cantidad y concentración inicial de los mismos para un volumen total de $10 \mathrm{~mL}$ de solución amortiguadora de lisis.

\begin{tabular}{|c|c|c|}
\hline Reactivo & Volumen & Objetivo \\
\hline $1 \mathrm{M}$ tris- $\mathrm{HCl}(\mathrm{pH} 8)$ & $100 \mu \mathrm{L}$ & Permeabilizar la membrana celular \\
\hline $1 \mathrm{M} \mathrm{EDTA}(\mathrm{pH} 8)$ & $1 \mathrm{~mL}$ & Estabilizante de DNA \\
\hline $10 \%$ SDS & $500 \mu \mathrm{L}$ & Detergente \\
\hline Rnasa A $20 \mathrm{mg} / \mathrm{ml}$ & $10 \mu \mathrm{L}$ & Degradación de RNA \\
\hline Proteinasa $\mathrm{K}$ & $50 \mu \mathrm{L}$ & Proteasa \\
\hline $\mathrm{H}_{2} \mathrm{O}$ & $8.39 \mathrm{~mL}$ & $\begin{array}{c}\text { Llevar la solución al volumen } \\
\text { adecuado }\end{array}$ \\
\hline Volumen Total & $\mathbf{1 0} \mathbf{~} \mathbf{L}$ & \\
\hline
\end{tabular}

Tras añadir la cantidad apropiada de solución amortiguadora de lisis, la muestra se incubó a $37^{\circ} \mathrm{C}$ durante una hora en un baño de agua. Tras este tiempo, se añadieron $50 \mu \mathrm{L}$ de proteinasa $\mathrm{K}(20 \mathrm{mg} / \mathrm{mL})$ hasta alcanzar una concentración final de $100 \mu \mathrm{g} / \mathrm{mL}$ y se incubó en un baño de agua a $50^{\circ} \mathrm{C}$ durante al menos 16 horas. 
Tras esta incubación se añadió un volumen 1:1 de fenol saturado (Fisher Scientific, Waltham, Massachussets, EE. UU.), se incubó con un suave movimiento durante 15 minutos a temperatura ambiente y se centrifugó a temperatura ambiente a 13.000 rpm durante 10 minutos. El sobrenadante se transfirió a un nuevo tubo, repitiendo dos veces más el proceso con fenol y otras dos veces más con cloroformo (Fisher Scientific, Waltham, Massachussets, EE. UU.).

Tras este último lavado se transfirió la muestra a la membrana de diálisis previamente preparada. El proceso de diálisis se llevo a cabo durante 24 horas a $4^{0} \mathrm{C}$ y suave rotación, con tres cambios de la solución de tampón (solución 1:100 de 20x de citrato sódico y cloruro sódico (SSC) (Fisher Scientific, Waltham, Massachussets, EE. UU.) con $\mathrm{ddH}_{2} \mathrm{O}$ ).

Con el fin de disminuir el volumen de la muestra se utilizaron cristales de polietilenglicol (Fluka, Sigma Aldrich, Suiza) para retirar el exceso de agua mediante ósmosis. Una vez que se alcanzó el volumen de DNA deseado $(\sim 200 \mu \mathrm{l})$, se transfirió a un nuevo tubo, se cuantificó mediante técnicas espectrofotométricas (Nanodrop Technologies, Rockland, Dinamarca) y se almacenó en una solución de TE 1X (obtenido a partir de una solución 100X $1 \mathrm{M}$ Tris - 0,1 M EDTA) a $4^{\circ} \mathrm{C}$ hasta su uso.

\subsubsection{Purificación del RNA}

Aproximadamente la cuarta parte de las células de cada muestra ( $\sim 10^{6}$ células) se reservó para realizar estudios de expresión. Una vez terminado el proceso de selección celular, a los linfocitos $\mathrm{CD}_{19}{ }^{+}$se les añadió $1 \mathrm{~mL}$ de TRIzoL (Invitrogen, 
Carlsbad, California, EE. UU.), según las recomendaciones del fabricante. Las muestras fueron guardadas a $-80^{\circ} \mathrm{C}$ hasta el momento de la purificación.

Para prevenir la posible degradación del RNA durante el tiempo en el que se estuvo trabajando con el mismo, todo el material utilizado fue estéril y libre de RNasas. En todos los casos las muestras fueron homogenizadas durante aproximadamente cinco minutos a temperatura ambiente, con el fin de permitir la completa disociación de complejos nucleoprotéicos.

Tras esto, se añadieron $0,2 \mathrm{~mL}$ de cloroformo por cada mililitro de TRIzoL utilizado y se agitó la muestra durante unos 15 segundos, para después dejarla a temperatura ambiente y en reposo durante 3 minutos. Inmediatamente después se centrifugó a no más de $14.000 \mathrm{rpm}$ durante 15 minutos a $4^{\circ} \mathrm{C}$. Tras esta centrifugación, se pudieron observar tres fases: la de mayor densidad y de color rosado, formada por la mezcla de fenol-cloroformo; una interfase, con el contenido proteico de las células y una fase superior, acuosa e incolora, que contenía el RNA.

Con el objetivo de precipitar el RNA, se transfirió la fase acuosa a un nuevo tubo, al que se añadieron 0,5 mL de isopropanol. Tras la homogeneización de la muestra, se dejó a temperatura ambiente durante 10 minutos y se centrifugó a no más de 14.000 rpm durante otros 10 minutos a $4^{\circ} \mathrm{C}$. En los casos en los que el RNA era suficiente, se pudo ver un pellet incoloro en el fondo del tubo.

Para lavar el pellet, se utilizó $1 \mathrm{~mL}$ de etanol al 75\%. Tras la homogeneización mediante suave vórtex, la muestra se centrifugó a 10.000rpm durante 5 minutos a $4^{0} \mathrm{C}$. Tras este periodo, el pellet se dejó secar al aire y se resuspendió en $30 \mu \mathrm{L}$ de 
agua libre de RNasas y DNasas. Tras cuantificar la cantidad de RNA en cada muestra, fueron guardadas a $-80^{\circ} \mathrm{C}$ hasta su posterior uso.

\subsubsection{Cuantificación de Ácidos Nucleicos}

En ambos casos, la concentración de DNA o RNA se determinó en todas las muestras con un espectrofotómetro Nanodrop ND-100 (Nanodrop Technologies, Rockland, Dinamarca). Para las muestras de DNA se determinó la absorbancia a 260 nm de $1 \mu \mathrm{L}$ de cada muestra, utilizando el coeficiente de extinción de 0,02 ( $\mu \mathrm{g} / \mathrm{mL}$ )$^{-1 *} \mathrm{~cm}^{-1}$ característico del DNA. Para el RNA, el coeficiente de extinción molar utilizado fue $0,025(\mu \mathrm{g} / \mathrm{mL})^{-1 *} \mathrm{~cm}^{-1}$. En ambos casos, la pureza de las preparaciones se determinó calculando la relación entre las absorbancias a 260 y 280 nm, que osciló entre 1,7 y 1,9.

\subsubsection{Obtención de dscDNA a partir del RNA}

La síntesis del cDNA monocatenario a partir del RNA se llevó a cabo usando el kit Superscript III de Invitrogen (Invitrogen, Carlsbad, California, EE. UU.). Se diseñó un oligo que contenía el promotor de la polimerasa T7. En este caso, el oligo se purifica mediante HPLC, ya que es importante que no haya contaminantes. La secuencia se muestra a continuación:

5'-GGCCAGTGAATTGTAATACGACTCACTATAGGGAGGCGG(T) 24-3'

Según este protocolo, se incubaron durante 5 minutos a $65^{\circ} \mathrm{C}, 7 \mu \mathrm{L}$ de la muestra inicial de RNA, $1 \mu \mathrm{L}$ al $10 \mathrm{mM}$ de una mezcla de dNTPs y $2 \mu \mathrm{L}$ de una solución 50 $\mu \mathrm{M}$ del oligo anteriormente indicado (en un volumen final de la reacción de $10 \mu \mathrm{l}$ ). 
Tras esta incubación, la muestra se dejó enfriar en hielo durante otro par de minutos. Una vez que la muestra se hubo enfriado, a cada reacción se añadieron 2 $\mu \mathrm{L}$ de RT Buffer 10X, $2 \mu \mathrm{L}$ 0,1M DTT, $4 \mu \mathrm{L}$ de $\mathrm{MgCl}_{2} 25 \mathrm{mM}, 1 \mu \mathrm{L}$ de RNaseOUT (40

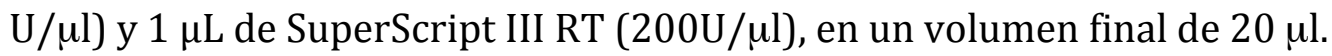

La reacción se llevó a cabo en un termociclador Veriti ${ }^{\mathrm{TM}}$ 96-Well Fast ThermalCycler (Applied Biosystems Inc., California, EE. UU.). Las muestras se incubaron como sigue:

10 minutos a $25^{\circ} \mathrm{C}$,

50 minutos a $50^{\circ} \mathrm{C}$

10 minutos a $85^{\circ} \mathrm{C}$

A continuación se obtuvo el cDNA bicatenario. A cada muestra se le añadieron 30 $\mu \mathrm{L}$ de SecondStrand Buffer 5X*, $3 \mu \mathrm{L}$ de dNTP con una concentración $10 \mathrm{mM}, 1 \mu \mathrm{L}$ de BSA ( $1 \mu \mathrm{g} / \mu \mathrm{l}), 1 \mu \mathrm{L}$ de DNA Ligasa* de Escherichia coli , $4 \mu \mathrm{L}$ de DNA Polimerasa I (10 U/ $\mu$ l)* purificada de E. coli y $90 \mu \mathrm{L}$ de agua libre de RNasas.

* No se incluyen en el Kit anteriormente citado y se solicitaron de forma independiente a Invitrogen (Invitrogen, Carlsbad, California, EE. UU.).

Tras asegurarnos de que la mezcla era homogénea, se incubó en un termociclador Veriti $^{\text {TM }}$ 96-Well Fast ThermalCycler durante dos horas a $16^{\circ} \mathrm{C}$. Tras este período, a cada muestra se añadieron $2 \mu \mathrm{L}$ de T4 DNA polimerasa (Invitrogen, Carlsbad, California, EE. UU.) y se dejó otros 10 minutos a $16^{\circ} \mathrm{C}$. La reacción se terminó añadiendo $10 \mu \mathrm{L}$ de EDTA 0,5M. 
El producto de esta reacción se purificó usando un Kit de purificación de DNA proporcionado por Qiagen (QIAGEN Inc., Valencia, California, EE. UU.), usando columnas MinElute.

\subsubsection{Amplificación del RNA}

Para la amplificación del RNA se utilizó el kit MEGAScript@ (Ambion, Applied Biosystems Inc, California, EE. UU.), un método de amplificación lineal llevado a cabo por la polimerasa T7 que ha demostrado previamente ser útil en estudios de expresión basados en micromatrices (microarrays)(191).

La reacción de transcripción se llevó a cabo según las recomendaciones del fabricante en un ambiente libre de RNAsas. A cada muestra se añadieron $2 \mu \mathrm{L}$ de ATP solution, CTP solution, GTP solution y UTP solution, además de $2 \mu \mathrm{L}$ de $10 X$ Reaction Buffer y $2 \mu \mathrm{L}$ de Enzime Mix. La cantidad total de cDNA debe oscilar entre 0,1 y $1 \mu$ g. Se añadió la cantidad de agua libre de RNAsas necesaria hasta alcanzar un volumen final de $20 \mu \mathrm{L}$.

El tiempo de incubación de la mezcla fue en todos los casos de al menos 16 horas en un termociclador Veriti ${ }^{\mathrm{TM}}$ 96-Well Fast Thermal Cycler a $37^{\circ} \mathrm{C}$.

Tras este periodo el RNA fue purificado usando el sistema MinElute Colums (Qiagen, Valencia, California, EE. UU.), según el protocolo especificado por la casa comercial. 


\subsubsection{PCR cuantitativa (Q-PCR)}

La PCR cuantitativa a tiempo real es un método que permite hacer un cálculo aproximado de la cantidad de una secuencia nucleica concreta, en este caso mRNA, en una muestra determinada.

En este trabajo se empleó el sistema LightCycler® 480 SYBR Green I Master Mix (Roche Applied Science, Indianápolis, EE. UU.) según las recomendaciones del fabricante. El volumen final en cada reacción fue de $10 \mu \mathrm{L}$ y en todos los casos las muestras se analizaron por triplicado. La cantidad de partida para cada reacción fue de $500 \mathrm{ng}$ y la concentración final de cada oligo fue de 0,5 $\mu \mathrm{M}$. Para cada muestra, se añadieron $5 \mu \mathrm{L}$ de $2 \mathrm{X}$ LightCycler® Master Mix. En todos los casos se utilizó como control negativo una cantidad proporcional de agua de alto grado molecular.

Para la lectura se utilizó el LightCycler® 480 Instrument (Roche AppliedScience, Indianápolis, EE. UU.), adaptado para placas de 96 pocillos. El diseño del programa se detalla a continuación:

Tabla 5. Programa utilizado para la realización de la PCR cuantitativa.

\begin{tabular}{|c|c|c|}
\hline Nombre del Programa & Ciclos & Modo de Análisis \\
\hline Pre-Incubación & 1 & Ninguno \\
\hline Amplificación & 45 & Cuantificación \\
\hline Curvas de fusión & 1 & Curvas de Fusión \\
\hline Mantenimiento & 1 & Ninguno \\
\hline
\end{tabular}

\begin{tabular}{|c|c|c|c|c|}
\hline $\begin{array}{c}\text { Temperatura } \\
\left({ }^{\circ} \mathrm{C} /\right)\end{array}$ & $\begin{array}{c}\text { Modo de } \\
\text { Adquisición }\end{array}$ & $\begin{array}{l}\text { Tiempo } \\
\text { (mm:ss) }\end{array}$ & $\begin{array}{c}\text { Rampa de } \\
\text { temperatura }\left({ }^{\circ} \mathrm{C} / \mathrm{s}\right)\end{array}$ & $\begin{array}{c}\text { Adquisiciones } \\
\text { (por }{ }^{\circ} \mathrm{C} \text { ) }\end{array}$ \\
\hline \multicolumn{5}{|l|}{ Pre-Incubación } \\
\hline 95 & Ninguno & $05: 00$ & 4.4 & - \\
\hline \multicolumn{5}{|l|}{ Amplificación } \\
\hline 95 & Ninguno & $00: 10$ & 4.4 & - \\
\hline 60 & Ninguno & $00: 10$ & 2.2 & - \\
\hline 72 & & $00: 10$ & 4.4 & - \\
\hline \multicolumn{5}{|l|}{ Curvas de fusión } \\
\hline 95 & Ninguno & $00: 05$ & 4.4 & - \\
\hline 65 & Ninguno & $01: 00$ & 2.2 & - \\
\hline 97 & Continuo & - & - & $5-10$ \\
\hline
\end{tabular}


Los oligos se diseñaron con el software disponible en la página http://www.idtdna.com/SCITOOLS/scitools.aspx, usando la aplicación específica para PCR en tiempo real. Con el fin de evitar amplificaciones inespecíficas, uno de los criterios utilizados en el diseño de estos oligos fue el que anillaran en secuencias exónicas con al menos un intrón de separación.

La secuencia de los oligos se detalla a continuación. En la tabla 6 se especifica el nombre, el genoma de referencia utilizado para el diseño, la secuencia de los oligos, la $\mathrm{T}$ de anillamiento óptima (Tan) para la reacción y la posición cromosómica del amplicón resultante según el genoma de referencia utilizado.

Tabla 6. Oligos utilizados en los experimentos de PCR cuantitativa.

\begin{tabular}{|c|c|c|l|c|c|}
\hline Nombre & Genoma & Orientación & \multicolumn{1}{|c|}{ PCR primer } & Tan & Posición cromosómica \\
\hline \multirow{2}{*}{ CYP26 } & \multirow{2}{*}{ HG18 } & Forward & GACTGAATCCCCCAGTTCC & \multirow{2}{*}{60} & \multirow{2}{*}{ chr10:94,836,395-94,836,752 } \\
\cline { 3 - 5 } & & Reverse & GATAACATTCCAGCCCTTGG & & \\
\hline \multirow{2}{*}{ GAPDH } & \multirow{2}{*}{ HG18 } & Forward & CCACATCGCTCAGACACCAT & \multirow{2}{*}{60} & chr12:6,643,981-6,645,682 \\
\cline { 3 - 4 } & & Reverse & CCAGGCGCCCAATACG & & \\
\hline
\end{tabular}

Para calcular la expresión relativa del gen de interés se empleó el método de Livak $\left(2^{-\Delta C_{\mathrm{T}}}\right)$ (192). En este método se asume que la eficacia de los oligos en la amplificación es cercana al $100 \%$, por lo que fue necesario comprobarlo en los oligos utilizados.

La eficiencia de los oligos se determinó mediante diluciones seriadas de una concentración inicial conocida y usando los valores $\mathrm{C}_{\mathrm{T}}$ para generar una curva estándar. En general, estas curvas estándar se construyen representando el valor logarítmico del factor de dilución frente al valor $\mathrm{C}_{\mathrm{T}}$ de cada dilución. En este caso, para evaluar la eficiencia se utilizó el coeficiente de determinación $\mathrm{R}^{2}$. 
En la figura 13 se muestran las curvas estándar de los oligos utilizados en este trabajo, junto con el coeficiente de determinación para CYP26A1 y GAPDH

Figura 13. Curvas estándar generadas a partir de diluciones seriadas para los oligos diseñados para A. CYP26A1 y B. GAPDH. El valor del coeficiente de determinación se muestra en cada caso, sobre la gráfica

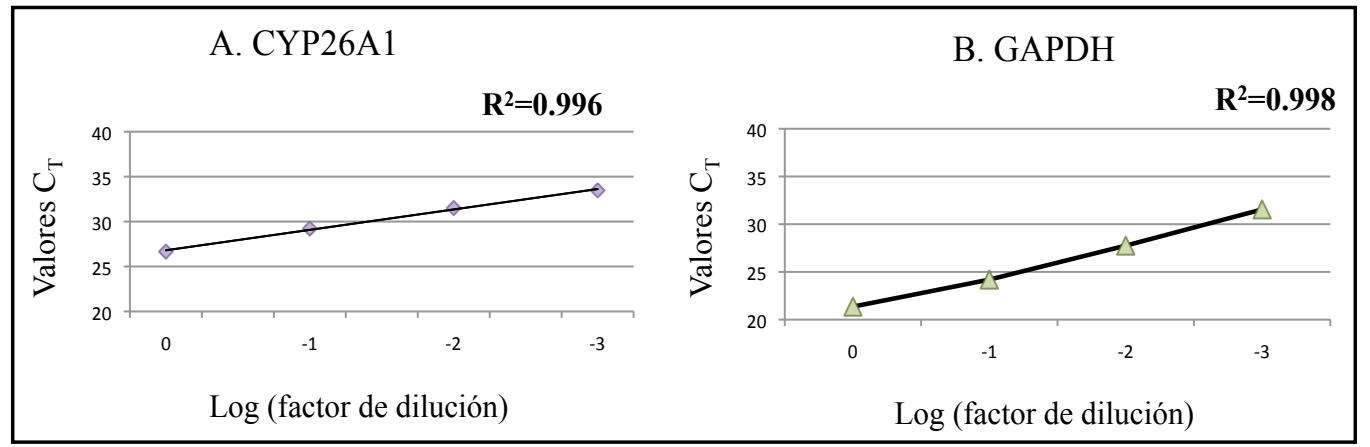

La eficacia de la amplificación (E), se calcula a partir de la pendiente de la curva estándar, usando la fórmula siguiente:

$$
\mathrm{E}=10^{-1 / \text { pendiente }}
$$

Lo ideal es que la cantidad de producto de la PCR se duplique tras cada paso de amplificación exponencial. Por lo que si queremos calcular el porcentaje de eficiencia $(\% \mathrm{E})$ :

$$
\% \mathrm{E}=(\mathrm{E}-1) * 100
$$

En una reacción ideal, en la que E=2:

$$
\% \mathrm{E}=(2-1) * 100=100 \%
$$


Los porcentajes de eficiencia en nuestro caso fueron 102,3\% para CYP26A1 y $105,5 \%$ para $G A P D H$.

El primer paso del análisis consistió en normalizar las $\mathrm{C}_{\mathrm{T}}$ tanto de las muestras de referencia, en nuestro caso controles, como las de alérgicos, usando otro gen de referencia. Estos genes de referencia, conocidos como housekeeping genes o genes constitutivos han demostrado tener unos niveles de expresión homogéneos y estables en diferentes tejidos de mamíferos. Para este trabajo utilizamos como referencia la expresión de GAPDH.

Las fórmulas utilizadas para la normalización con el gen constitutivo se detallan a continuación:

Alérgicos

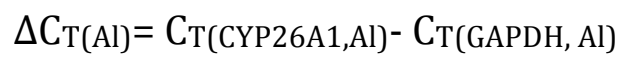

Controles

$$
\Delta \mathrm{C}_{\mathrm{T}(\mathrm{Cn})}=\mathrm{C}_{\mathrm{T}}(\mathrm{CYP} 26 \mathrm{~A} 1, \mathrm{Cn})-\mathrm{C}_{\mathrm{T}}(\mathrm{GAPDH}, \mathrm{Cn})
$$

En el paso siguiente se normalizaron los $\Delta \mathrm{C}_{\mathrm{T}} \mathrm{de}$ ambos grupos:

$$
\Delta \Delta \mathrm{C}_{\mathrm{T}}=\Delta \mathrm{C}_{\mathrm{T}(\mathrm{Al})}-\Delta \mathrm{C}_{\mathrm{T}(\mathrm{Cn})}
$$

Y por último se calculó el valor de la expresión proporcional:

$$
2^{-\Delta \Delta \mathrm{C}_{\mathrm{T}}}=\text { Ratio normalizado de la expresión }
$$


Mediante este método el resultado obtenido se interpreta como el incremento (o detrimento) en la expresión del gen de interés del grupo experimental (en nuestro caso los pacientes alérgicos) frente al grupo control, normalizado frente a GAPDH.

\subsubsection{HELP Assay}

\subsubsection{Descripción de la técnica}

Como método para el estudio de los patrones epigenéticos se eligió el HELP assay. Como se ha comentado anteriormente, esta aproximación al estudio de la metilación de las citosinas recibe su nombre de las siglas en inglés HpaII Tiny Fragments enrichment by ligation-mediated PCR y fue publicado por el grupo del Dr. Greally en el año 2006 (126) e implementado por el mismo grupo, trabajo publicado en el 2009 (193). Es esta última versión de la técnica la que usamos en este trabajo.

El HELP assay se basa en el uso de dos enzimas de restricción isoesquizómeras, MspI y HpaII. Ambas enzimas son capaces de reconocer la misma secuencia 5'CCGG-3'; sin embargo, MspI es capaz de cortar en todas las posibles dianas, mientras que HpaII sólo es capaz de cortar cuando la citosina central no está metilada, ya que es sensible a la metilación. De esta forma se puede comprobar que, tras la digestión de DNA genómico con HpaII, el DNA digerido permanece casi intacto, mostrando una banda de masa molecular elevada. A pesar de que la secuencia de restricción es corta (5'-CCGG-3') (194), el estado de hipermetilación característico del genoma hace que se encuentre protegido frente a la digestión 
con esta enzima. Una digestión en las mismas condiciones con MspI ofrece una visión bien distinta, debido a las características de la digestión de la misma.

Tras la digestión por separado con ambas enzimas de cada una de las muestras a analizar, se continuó con la creación de dos librerías mediante la ligación de unos adaptadores de secuencia conocida, que servirían después como cebadores para la amplificación mediante LM-PCR (de sus siglas en inglés Ligation Mediated PCR). Ambos productos de la digestión son después marcados con dos fluoróforos diferentes y los niveles de metilación analizados mediante cohibridación de los dos productos en un microarray, diseñado específicamente para representar todos los fragmentos posibles generados tras la digestión.

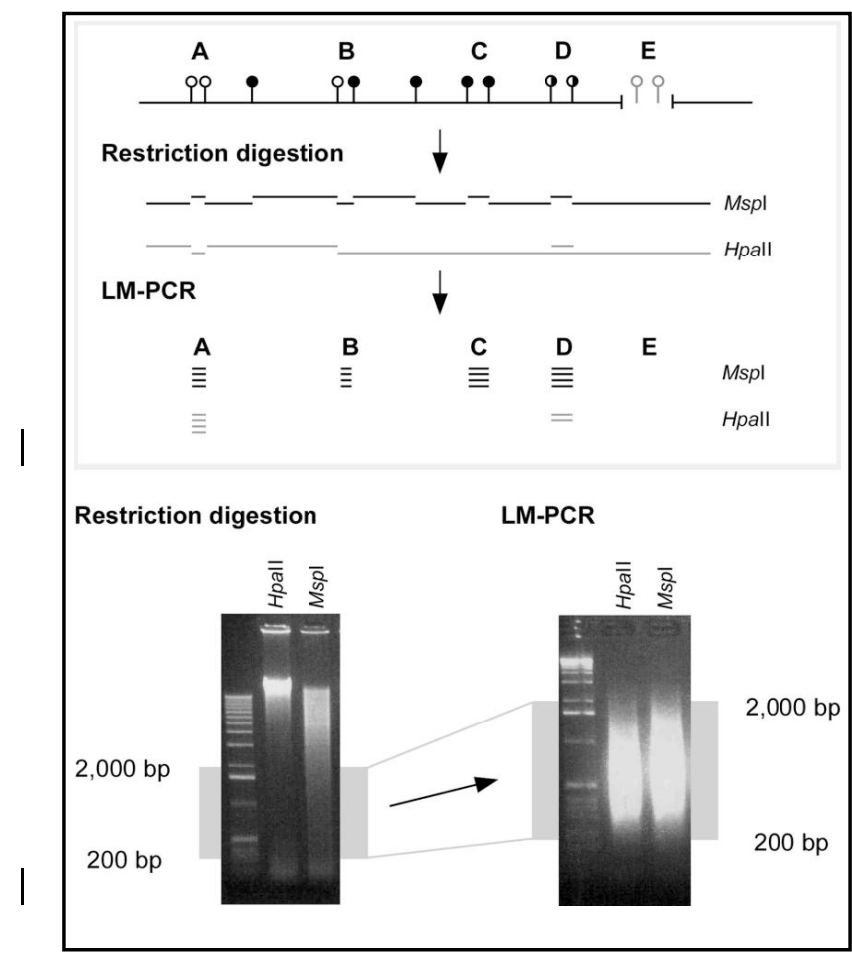

Figura 14. Principio del HELP assay. Este método se basa en la comparación de las representaciones genómicas tras la digestión de HpaII o su esquizómera ${ }_{2}$ MspI. En la primera versión de HELP, los fragmentos representados tenían una longitud de 200 a 2000 pb. En la nueva versión este rango se incrementó hasta incluir fragmentos de $50 \mathrm{pb}$. Mientras que loci como el representado en A debería estar representado tanto en HpaII como en MspI, considerando que HpaII no corta en los casos B y C, sólo tendremos la representación en MspI. La metilación parcial en D generaría una ratio HpaII/MspI menor que en el caso A. En la caso de que haya una mutación, como en el caso E, no se obtendrá señal alguna ni con_HpaII ni con MspI.(126) 
Entre las ventajas que ofrece el HELP están la sencillez técnica y la posibilidad de incluir controles internos mediante la comparación con el producto de la digestión de MspI. La señal de HpaII en un locus determinado puede estar influenciada no sólo por el estado de metilación sino también por el tamaño del fragmento, su composición nucleotídica (ambas variables influenciando la amplificación de la PCR) o posibles alteraciones en la secuencia del DNA (como variaciones en el número de copias o mutaciones en la secuencia diana de las enzimas de restricción). Debido a que la representación de $M s p I$ estará influenciada por las mismas variaciones, la expresión de la señal de HpaII en función de la proporcionada por MspI en cada locus, permite una adecuada comparación de los diferentes loci para la misma muestra de DNA, una comparación "intragenómica". Además, el HELP también permite el estudio de señales de intensidad entre distintas muestras, abriendo la posibilidad a una comparación "intergenómica" de las mismas.

El análisis e interpretación de los resultados suponen un gran desafío bioinformático. Así, el HELP assay presenta una serie de herramientas analíticas especialmente diseñadas para la interpretación de los resultados del array (195). Tras la adquisición de las imágenes, los arrays se someten a controles de calidad y normalización. Tras la agrupación de las diferentes señales que provienen de un mismo locus cromosómico, se calcula el valor logarítmico de la ratio de HpaII sobre MspI. Los diferentes estados de metilación son entonces definidos de forma matemática, con valores menores de cero que representan los loci metilados y con valores superiores a cero que definen los loci hipometilados. En definitiva, la distribución bimodal de las ratios HpaII/MspI permite una fácil diferenciación 
entre estados de hipermetilación o hipometilación, que tienen un significado fisiológico en el epigenoma y en el estado celular.

La visualización de los datos generados mediante HELP se llevó a cabo utilizando el buscador de la Universidad de Santa Cruz, en California, EE.UU. (http://genome.ucsc.edu/)

\subsubsection{Desarrollo metodológico}

En la mayoría de los casos se partió de $1 \mu \mathrm{g}$ de DNA por muestra para cada enzima. El primer tratamiento que recibió el DNA fue una digestión por separado con las enzimas de restricción isoesquizómeras MspI y HpaII (NEB, Ipswich, MA). El volumen final en todas las reacciones fue $200 \mu \mathrm{L}$. La incubación con las enzimas de restricción se llevó a cabo durante al menos 16 horas a $37^{\circ} \mathrm{C}$.

Con el fin de comprobar la calidad de la digestión, se visualizaron $10 \mu \mathrm{L}$ de cada muestra mediante electroforesis en gel de agarosa al 2\% . El DNA procedente del tratamiento con HpaII tenía una masa molecular elevada, mientras que el DNA procedente de la digestión con MspI presentó un rango de tamaños amplio y de menor masa molecular.

\subsubsection{Purificación}

Ya que la calidad del DNA es un factor crítico durante todo el proceso, el siguiente paso conlleva una purificación del DNA producto de las digestiones. Para ello, se 
añadieron $300 \mu \mathrm{L}$ de TE pH 8,0 y $500 \mu \mathrm{L}$ de una solución 1:1 de fenol saturado y cloroformo. La mezcla se centrifugó durante 10 minutos a 3.000 rpm.

A continuación se recogió la fase acuosa en un nuevo tubo (unos $500 \mu \mathrm{L}$ aproximadamente) y se añadió $1 \mu \mathrm{L}$ de glicógeno y $50 \mu \mathrm{L}$ de $\mathrm{NaOAc} 3 \mathrm{M}, \mathrm{pH}$ 5,2. Posteriormente se añadieron $800 \mu \mathrm{L}$ de isopropanol frío. La mezcla se mantuvo a $-20^{\circ} \mathrm{C}$ durante al menos 10 minutos. Transcurrido este tiempo, se sometió la muestra a una centrifugación de al menos $13.000 \mathrm{rpm}$ durante veinte minutos, y se descartó todo el sobrenadante.

El pellet se lavó con etanol al 70\% y se dejó secar al aire. Una vez que estuvo seco, se resuspendió en TE pH 8,0, obteniendo una concentración final de $1 \mu \mathrm{g} / 11 \mu \mathrm{L}$. En este punto, el DNA puede ser conservado a $-20^{\circ} \mathrm{C}$.

\subsubsection{Generación y amplificación de una librería de DNA}

El siguiente paso incluye la generación de una librería a partir de los fragmentos generados y se detalla a continuación. Cada muestra fue preparada según se detalla en la tabla 7. Se utilizó un termociclador iCycler de BioRad (BioRad Laboratories, California, EE. UU.). El programa empleado constaba de un primer paso a $55^{\circ} \mathrm{C}$ durante 5 minutos y a continuación un descenso progresivo de la temperatura durante una hora aproximadamente hasta alcanzar los $4^{\circ} \mathrm{C}$. Una vez alcanzada esta temperatura, se añadió $1 \mu \mathrm{L}$ de Ligasa T4 a cada reacción y se incubó durante unas 16 horas aproximadamente, a $16^{\circ} \mathrm{C}$. 
Tabla 7. Reactivos y respectivos volúmenes añadidos a cada muestra para llevar a cabo la reacción de ligación.

\begin{tabular}{|c|c|c|}
\cline { 2 - 3 } \multicolumn{1}{c|}{} & Volumen MspI & Volumen HpaII \\
\hline DNA & $11 \mu \mathrm{l}$ & $11 \mu \mathrm{L}$ \\
\hline JHpaII 12 6OD & $3.75 \mu \mathrm{L}$ & $3.75 \mu \mathrm{L}$ \\
\hline JHpaII 24 12 OD & $3.75 \mu \mathrm{L}$ & $3.75 \mu \mathrm{L}$ \\
\hline NHpaII 12 6 OD & $3.75 \mu \mathrm{L}$ & $3.75 \mu \mathrm{L}$ \\
\hline NHpaII 24 12 OD & $3.75 \mu \mathrm{L}$ & $3.75 \mu \mathrm{L}$ \\
\hline Ligasa T4 Buffer 5x & $6 \mu \mathrm{L}$ & $6 \mu \mathrm{L}$ \\
\hline Ligasa T4 & $1 \mu \mathrm{L}$ & $1 \mu \mathrm{L}$ \\
\hline
\end{tabular}

La secuencia de los oligos mencionados anteriormente se muestra en la tabla 8.

Tabla 8. Secuencia de los adaptadores utilizados en la preparación de la librería de DNA para HELP assay.

\begin{tabular}{|l|l|}
\hline \multicolumn{1}{|c|}{ Nombre } & \multicolumn{1}{|c|}{ Secuencia } \\
\hline JHpaII 12 & 5'-CGGCTGTTCATG-3' \\
\hline JHPAII 24 & 5'-CGACGTCGACTATCCATGAACAGC-3' \\
\hline NHpaII 12 & 5'-CGGCTTCCCTCG-3' \\
\hline NHpaII 24 & 5'-GCAACTGTGCTATCCGAGGGAAGC-3' \\
\hline
\end{tabular}

Tras este tiempo de incubación, se añadió TE hasta alcanzar una concentración final de DNA de $2,5 \mathrm{ng} / \mu \mathrm{L}$. En este punto, se pude conservar la muestra a $-20^{\circ} \mathrm{C}$ por un tiempo indefinido.

El paso siguiente implica una reacción de PCR para amplificar los productos de la ligación anterior. Con el objetivo de aumentar la concentración hasta llegar al menos a 6,5 $\mu$ g de DNA requeridos para la hibridación de los microarrays, aunque sin aumentar el sesgo que introducen estas técnicas, se aumentó el número de reacciones por muestra. Se preparó una solución maestra según se detalla en la 
tabla 9 y se dividió el volumen total en cuatro alícuotas de PCR (aproximadamente $100 \mu \mathrm{L}$ en cada tubo) y se incubó a $72^{\circ} \mathrm{C}$ durante 10 minutos. Trascurrido este tiempo se añadió $1 \mu \mathrm{L}$ de Taq Polimerasa (Invitrogen, Carlsbad, California, EE. UU.) a cada muestra.

Tabla 9. Reactivos y respectivos volúmenes para preparar la solución maestra de la PCR.

\begin{tabular}{|l|c|c|}
\cline { 2 - 3 } \multicolumn{1}{c|}{} & $\begin{array}{c}\text { Volumen } \\
\text { MspI }\end{array}$ & $\begin{array}{c}\text { Volumen } \\
\text { HpaII }\end{array}$ \\
\hline $\begin{array}{l}\text { Producto de la ligación } \\
\text { anterior }\end{array}$ & $40 \mu \mathrm{L}$ & $80 \mu \mathrm{L}$ \\
\hline JHpaII 24 & $8 \mu \mathrm{L}$ & $8 \mu \mathrm{L}$ \\
\hline NHpaII 24 & $8 \mu \mathrm{L}$ & $8 \mu \mathrm{L}$ \\
\hline 10X Invitrogen Taq Buffer & $40 \mu \mathrm{L}$ & $40 \mu \mathrm{L}$ \\
\hline 50mM MgCl & $16 \mu \mathrm{L}$ & $16 \mu \mathrm{L}$ \\
\hline $4 \mathrm{mM}$ dNTP mix & $32 \mu \mathrm{L}$ & $32 \mu \mathrm{L}$ \\
\hline 5M Betaina & $173 \mu \mathrm{L}$ & $133 \mu \mathrm{L}$ \\
\hline Volumen Total & $\mathbf{3 9 7} \boldsymbol{\mu L}$ & $\mathbf{3 9 7} \boldsymbol{\mu L}$ \\
\hline
\end{tabular}

El programa utilizado durante la amplificación se detalla a continuación. El termociclador utilizado, en todos los casos fue iCycler de BioRad (BioRadLaboratories, California, EE. UU.)

\section{PROGRAMA HELP}

$72^{\circ} \mathrm{C}, 10 \mathrm{~min}$.

\begin{tabular}{l|l}
20 ciclos & $95^{\circ} \mathrm{C}, 30 \mathrm{sec}$. \\
$72^{\circ} \mathrm{C}, 3 \mathrm{~min}$.
\end{tabular}

$72^{\circ} \mathrm{C}, 10 \mathrm{~min}$. 
Con el fin de comprobar el éxito del experimento, se preparó un gel de agarosa al $2 \%$ en el que se cargaron $10 \mu \mathrm{L}$ de cada muestra.

Para finalizar el proceso, el producto de la PCR se purificó utilizando un método de extracción en fase sólida proporcionado por QIAGEN (Qiagen, Valencia, California, EE. UU.), según las instrucciones del fabricante.

\subsubsection{Hibridación en Microarrays}

Con el fin de determinar la proporción de fragmentos generados por HpaII (no metilados), los productos de PCR generados mediante HELP se marcaron con dos fluoróforos diferentes (Cy3 y Cy5 para HpaII y MspI, respectivamente) y se co-hibridaron en una membrana de microarray de Nimblegen (Roche NimbleGen, Islandia), específicamente diseñada para cubrir zonas del genoma que contuvieran sitios de corte HpaII consecutivos. Estos sitios se presentan a diferentes intervalos en el genoma humano, pero debido a que la amplificación de los fragmentos va desde 20 hasta 2000 pares de bases, sólo estas zonas han sido incluidas en el array. Se ha estimado que en el genoma humano hay presentes más de 1,5 millones de estos

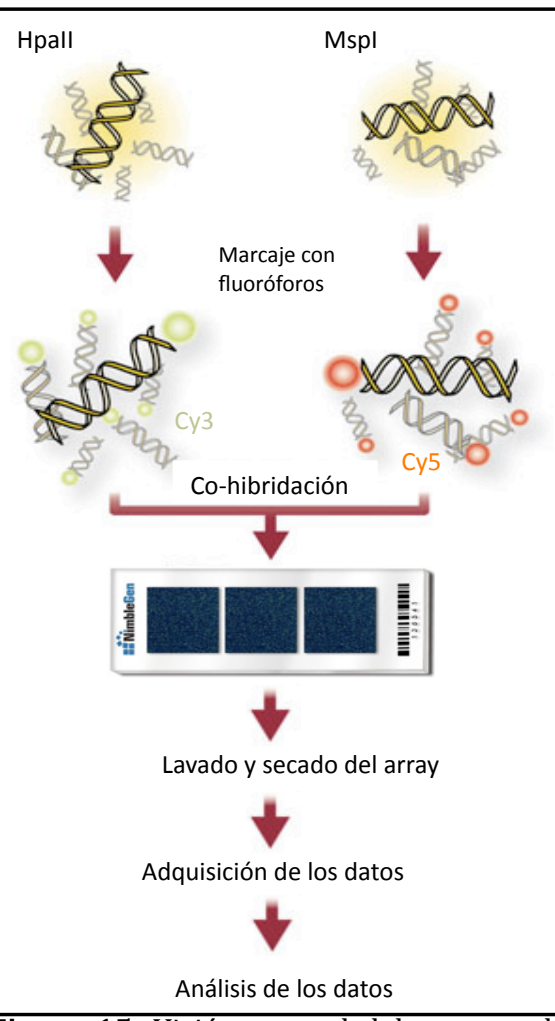

Figura 15. Visión general del proceso de marcaje, hibridación, adquisición y análisis de los datos. Las librerías generadas por la digestión de MspI y HpaII para una misma muestra se marcan con distintos fluoróforos para después co-hibridarlos en un mismo array. 
fragmentos, de los cuales casi el $90 \%$ está representado en los microarrays utilizados en este estudio.

El protocolo que se detalla a continuación fue el provisto por Nimblegen (Roche NimbleGen, Islandia) para arrays HD2, con pequeñas variaciones del mismo, también indicadas por el fabricante.

Antes de empezar la hibridación todas las muestras fueron analizadas mediante Byoanalizer (Agilent Technologies California, EE. UU.). Como se puede ver en la figura 16 los fragmentos generados mediante HELP presentan una distribución de tamaños característica, según se hubiera realizado la digestión con HpaII o MspI.

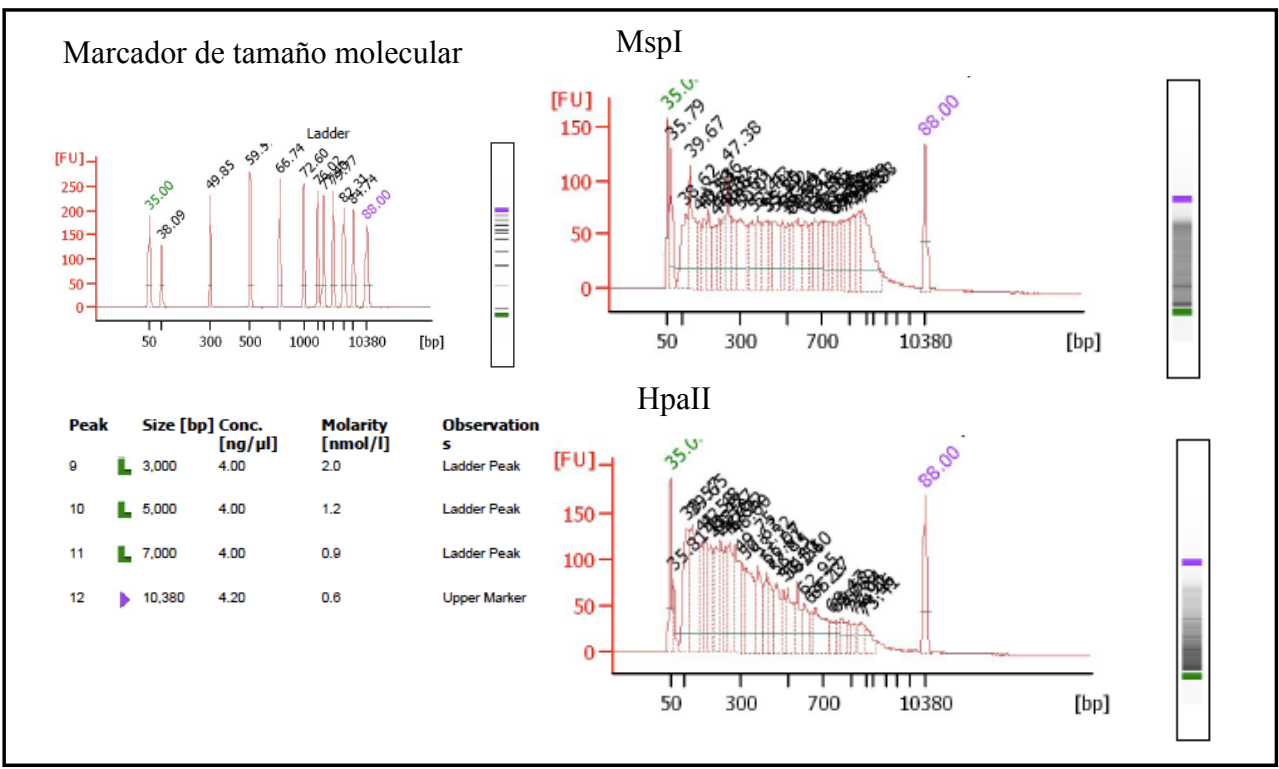

Figura 16. Resultados de un chip de DNA de Agilent. En la imagen se muestra el marcador de tamaño molecular y el resultado de HELP assay de una misma muestra tratada con MspI o HpaII

Para cada muestra, HpaII y MspI, se prepararon reacciones por duplicado. La cantidad de muestra inicial fue de $1 \mu \mathrm{g}$, a los cuales se añadieron $40 \mu \mathrm{L}$ de oligo 
marcados con Cy3 o Cy5 según la digestión se hiciera con HpaII o MspI, respectivamente. Se ajustó el volumen con agua de grado molecular hasta alcanzar un volumen total de $80 \mu \mathrm{l}$.

Las muestras se desnaturalizaron a $98^{\circ} \mathrm{C}$ durante 10 minutos y a continuación se dejaron enfriar en hielo durante 2 minutos. La eficacia de este paso es crítica para el éxito del proceso. Se utilizó la actividad exonucleasa $3^{\prime} \rightarrow 5^{\prime}$ y polimerasa del fragmento de Klenow para sintetizar cadenas dobles marcadas con el fluoróforo. Para ello, se preparó para cada reacción una mezcla maestra que contenía 50X dNTPs y $2 \mu \mathrm{L}$ de Klenow en un volumen total de $20 \mu$ l. El conjunto se dejó en incubación a $37^{\circ} \mathrm{C}$ durante dos horas protegido de la luz.

Una vez transcurrido este tiempo, a cada muestra se añadieron $10 \mu \mathrm{L}$ de EDTA $0,5 \mathrm{M}$ para parar la reacción y $11,5 \mu \mathrm{L}$ de $\mathrm{NaCl} 5 \mathrm{M}$ y se combinaron los duplicados. La mezcla se traspasó a un tubo de 1,5 mL que contenía $220 \mu \mathrm{L}$ de isopropanol. Tras una centrifugación a $14.000 \mathrm{rpm}$ durante 10 minutos se retiró el sobrenadante. Para lavar el pellet resultante se añadieron $500 \mu \mathrm{L}$ de etanol frío al $80 \%$ y se volvió a centrifugar a $14.000 \mathrm{rpm}$ durante 2 minutos. Tras retirar el sobrenadante, el pellet se secó usando una centrífuga de vacío SpeedVac a temperatura media durante 10 minutos. El pellet resultante se reconstituyó con 25 $\mu \mathrm{L}$ de agua de alto grado molecular.

La cantidad necesaria de DNA para cada microarray es de $34 \mu \mathrm{g}$ por cada enzima de restricción. Tras calcular la cantidad total de cada reacción se volvió a deshidratar mediante SpeedVac y se resuspendió en $12,3 \mu \mathrm{L}$ de agua de alto grado molecular. 
Tras preparar la solución de hibridación, se añadieron 31,7 $\mu \mathrm{L}$ de la misma a la muestra y el conjunto se incubó a $95^{\circ} \mathrm{C}$ durante 5 minutos protegido de la luz. Durante este tiempo se prepararon las plataformas HD2 diseñadas especialmente para adaptarse a las características de HELP assay.

Las muestras se incubaron durante una noche a $42^{\circ} \mathrm{C}$ en ausencia de luz. Tras esta incubación, se procedió al lavado y adquisición de las imágenes.

\subsubsection{Análisis de los datos}

Tras la hibridación y adquisición de las imágenes se generaron dos archivos con datos para cada muestra, uno para MspI y otro para HpaII.

Dado que MspI representa el total de todos los posibles fragmentos y es, por tanto, considerado como control negativo del método, cualquier fragmento del estudio que no genere señal para MspI, bien por motivos biológicos o bien por motivos técnicos, deberá ser excluido. Entre los motivos biológicos encontramos deleciones genómicas o mutaciones en los sitios de restricción que causarían la pérdida de ese sitio de restricción; entre los motivos técnicos se encuentran la pérdida del fragmento durante la amplificación de la PCR o fallos durante el marcaje o la hibridación en las membranas.

La proporción relativa de fragmentos de HpaII y MspI debe calcularse para cada locus. La distribución de la población de estos fragmentos sigue una curva bimodal, que representa las fracciones metiladas y no metiladas en el genoma. Mediante el uso de pequeñas sondas de 50 nucleótidos distribuidas de forma 
aleatoria en el array, se puede definir matemáticamente el "ruido" dentro del experimento, ya que proporcionan valores de la fluorescencia de fondo. Para cada muestra se generaron dos archivos .pair, uno para MspI y otro para HpaII, con los valores de la intensidad de cada fragmento. Los datos de intensidad para cada punto en el array son comparados con las sondas distribuidas en el array e identificados como loci concretos dentro del genoma.

Antes de poder considerar la variación biológica dentro del grupo de muestras, se llevaron a cabo controles de calidad del experimento para controlar la posible variación experimental. Primero se buscaron artefactos espaciales mediante una comparación de las medias de los valores de la ratio de intensidad HpaII/MspI. Para ello, se dividió el array en 25 sectores y se tomaron medias de los valores para cada cuadrante, comparándolos entre sí. Cuando la hibridación en el array fue de alta calidad, la distribución de estos valores apareció uniforme, mientras que una mala hibridación resultó en una distribución de los valores poco uniforme y requirió una repetición de la hibridación. Con el fin de facilitar la visualización de estos resultados, en verde se presentaron los valores de ratio inferiores a la media del array mientras que en rojo se representaron los valores superiores a la media del array (ver figura 21 en la sección de Material y Métodos).

Con el fin de mejorar la calidad de los datos, se definió un valor de intensidad prototipo para cada señal y para cada ratio HpaII/MspI, centrando cada grupo de valores, seguido de una normalización de los valores de intensidad del array. Tras esto, se calculó el logaritmo de la intensidad o el logaritmo de la ratio para cada punto en el array y se procedió a la comparación de estos valores con los valores de todos los arrays. 
Cuando se visualizaron valores de intensidad en función de la longitud del fragmento se pudo observar que la mayor intensidad de los fragmentos se encuentra alrededor de 500 pares de bases, con señales de intensidad menos abundantes en los extremos. También se pudo comprobar que en las representaciones de $M s p I$ todos los fragmentos generados en la digestión estaban representados, mientras que la representación de las intensidades de los fragmentos de HpaII mostraba una segunda población con valores de menor intensidad independientemente de la longitud del fragmento. Esta segunda población correspondía a fragmentos que no fueron digeridos o amplificados correctamente debido al estado de metilación de las zonas adyacentes a los sitios de corte HpaII. La representación de la ratio HpaII/MspI presentaba una distribución bimodal, con los valores de ratio inferiores representando metilación y los mayores representando una relativa hipometilación.

Como se ha comentado anteriormente, para cada experimento de HELP la señal de fondo fue calculada a partir de cientos de oligos de 50 mer de longitud y secuencia aleatoria, repartidos al azar por la membrana. Los valores de intensidad de estas sondas sirvieron como referencia para eliminar todos aquellos valores que estuvieran por debajo de este valor umbral, ya que se consideran fallidos, bien por razones experimentales, bien por razones biológicas. En el caso de que fueran sólo los valores de intensidad de HpaII los que estuvieran por debajo del umbral establecido como óptimo, estos valores fueron conservados ya que puede deberse a un estado de relativa hipometilación en ese loci concreto.

Para analizar la relación de similitud o diferencia en nivel global entre las diferentes muestras se calculó la p de Pearson para cada par de muestras, 
representando todas las posibles combinaciones entre las muestras, agrupando después cada muestra según su similitud mediante un método de agrupaciones no supervisado utilizando el método de varianza mínima de Wards y matrices de distancias euclidianas.

Para visualizar los datos obtenidos mediante esta técnica de una forma más local, asociando cada valor de intensidad con una región cromosómica concreta, se generaron archivos .wig compatibles con el Buscador Genómico de la Universidad Santa Cruz de California (UCSC Genome Browser, http://genome.ucsc.edu/).

Este análisis, optimizado para el HELP assay, se encuentra disponible en la dirección web http://greallylab.aecom.yu.edu/ greally/HELP pipeline/. El paquete se puede utilizar a través del programa estadístico R (196).

\subsubsection{Tratamiento con Bisulfito sódico}

El tratamiento del DNA con Bisulfito Sódico es quizá uno de los métodos más usados en el estudio de metilación de citosinas, ya que precede a la mayoría de las técnicas cuantitativas o cualitativas basadas en PCR. Este método se basa en la modificación de citosinas no metiladas en uracilos, mientras que las citosinas metiladas permanecen como tal.

El bisulfito sódico desamina citosinas sin metilar de cadenas sencillas de DNA. El producto intermedio que se forma en un medio ácido, la 5,6-dihidrocitosina-6sulfonato sódico, se transforma en uracilo en un medio alcalino debido a la degradación del bisulfito. Durante este tratamiento, las citosinas metiladas 
también están sujetas a un proceso de desaminación, que las convertirá en timinas. Sin embargo, la reacción es tan lenta que no se llega a la formación del producto final.

Los periodos de incubación con bisulfito sódico superiores a 16 horas pueden llegar a dañar más del $60 \%$ de las bases púricas y los enlaces fosfodiéster en el DNA y destruir las bases pirimidínicas. El cambio a un $\mathrm{pH}$ alcalino genera la creación de sitios libres en las purinas y pirimidinas, debido a las roturas de los enlaces $\mathrm{N}$-glicosídicos. Los tiempos de incubación demasiado prolongados, las altas temperaturas y las concentraciones elevadas de bisulfito sódico pueden llegar a degradar entre el 84-96\% del DNA, mientras que condiciones menos agresivas pueden resultar en una conversión incompleta de las citosinas no metiladas en uracilos $(122,197)$.

Tras la amplificación mediante PCR del material tratado con bisulfito, los uracilos procedentes de las citosinas sin metilar se convierten en timinas y las cadenas de DNA no son complementarias, por lo que los oligos que se diseñan para este tipo de experimentos suelen ser específicos para una cadena concreta.

\subsubsection{Tratamiento del DNA con EZ DNA Methylation Direct Kit}

El tratamiento con bisulfito se realizó en este trabajo usando un kit comercial, suministrado por Zymo Research (ZymoResearch Corp, California, EE. UU.). Con este método, eficaz y rápido, la eficiencia en la conversión de citosinas no metiladas es superior al 99,5\%, así como lo es la protección de las citosinas metiladas. 
El método se basa en una extracción en fase sólida. Una vez que se ha llevado a cabo la conversión con bisulfito sódico, el DNA tratado se une a un filtro de sílice a elevadas concentraciones salinas, donde se lleva a cabo el tratamiento de desulfonación y purificación del DNA. Una vez el tratamiento ha concluido, el DNA se eluye con una solución amortiguadora de baja concentración salina.

Según las recomendaciones del fabricante, la cantidad de DNA óptima para una completa conversión son 500 ng. Tras calcular el volumen necesario para cada muestra, el volumen se ajustó con agua ultrapura hasta alcanzar $20 \mu \mathrm{L}$ en un tubo de PCR, al que se añadieron $130 \mu \mathrm{L}$ de CT conversion Reagent. Las muestras se colocaron en un termociclador Veriti ${ }^{\mathrm{TM}}$ 96-Well Fast ThermalCycler (Applied Biosystems Inc., California, EE. UU.), con el programa siguiente:

$98^{\circ} \mathrm{C}$ durante 10 minutos

$64^{\circ} \mathrm{C}$ durante tres horas y media

$4^{0} \mathrm{C}$ hasta un máximo de 20 horas

Durante este tiempo se desarrolló la conversión de citosinas no metiladas en uracilos. Tras este período, se añadieron $600 \mu \mathrm{L}$ de M-Binding Buffer (solución de alta concentración salina) a cada columna (Zymo-Spin ${ }^{T M} I C$ Column), con el fin de preparar el filtro donde se unirá el DNA. Las muestras previamente tratadas se transfirieron a esta columna y el conjunto se mezcló varias veces por inversión. Tras una breve centrifugación ( $\geq 12.000 \mathrm{rpm}$ durante 30 segundos) se procedió a un lavado de la membrana con $100 \mu \mathrm{L}$ de M-Wash Buffer y posterior centrifugación. Tras descartar el sobrenadante, se añadieron $200 \mu \mathrm{L}$ de $M$ Desulphonation Buffer y se dejó a temperatura ambiente durante 15 o 20 minutos. 
Transcurrido este tiempo, se procedió a una breve centrifugación y lavado de la membrana por duplicado con $200 \mu \mathrm{L}$ de $M$-Wash Buffer seguido de centrifugación.

Las muestras se eluyeron añadiendo $10 \mu \mathrm{L}$ de M-Elution Buffer a cada membrana. La concentración final de todas las muestras se ajustó con 1X TE hasta alcanzar $5 \mathrm{ng} / \mu \mathrm{L}$.

\subsubsection{Espectrometría de masas}

Como ya se ha comentando antes, existen numerosas técnicas que permiten una cuantificación relativa de los niveles de conversión de citosinas a timinas tras el tratamiento con bisulfito sódico, entre los que se encuentran la clonación seguida de secuenciación directa o secuenciación masiva de todo el genoma. Estos valores se pueden examinar también mediante pirosecuenciación o espectrometría de masas.

En este trabajo, la cuantificación de los niveles de metilación de una forma precisa, tras el tratamiento del DNA genómico con bisulfito sódico y amplificación de fragmento deseado mediante PCR, se llevó a cabo un análisis mediante espectrometría de masas (Sequenom, California, EE. UU.). Los valores de metilación para cada CpG analizado mediante esta técnica se ha demostrado que son de una exactitud de $\pm 5 \%$ (124)

El producto de la PCR se transcribe in vitro en una molécula de RNA monocatenario y es esta molécula la que se somete a un proceso de corte específico con una endorribonucleasa determinada. El cambio de citosinas no metiladas a uracilos durante el tratamiento con bisulfito sódico y el posterior 
cambio a timinas generará productos específicos de la digestión que pueden ser analizados mediante espectrometría de masas MALDI-TOF (de sus siglas en inglés

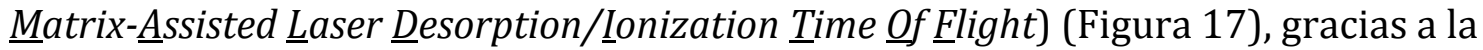
diferencia de masas que existe entre las bases nitrogenadas.

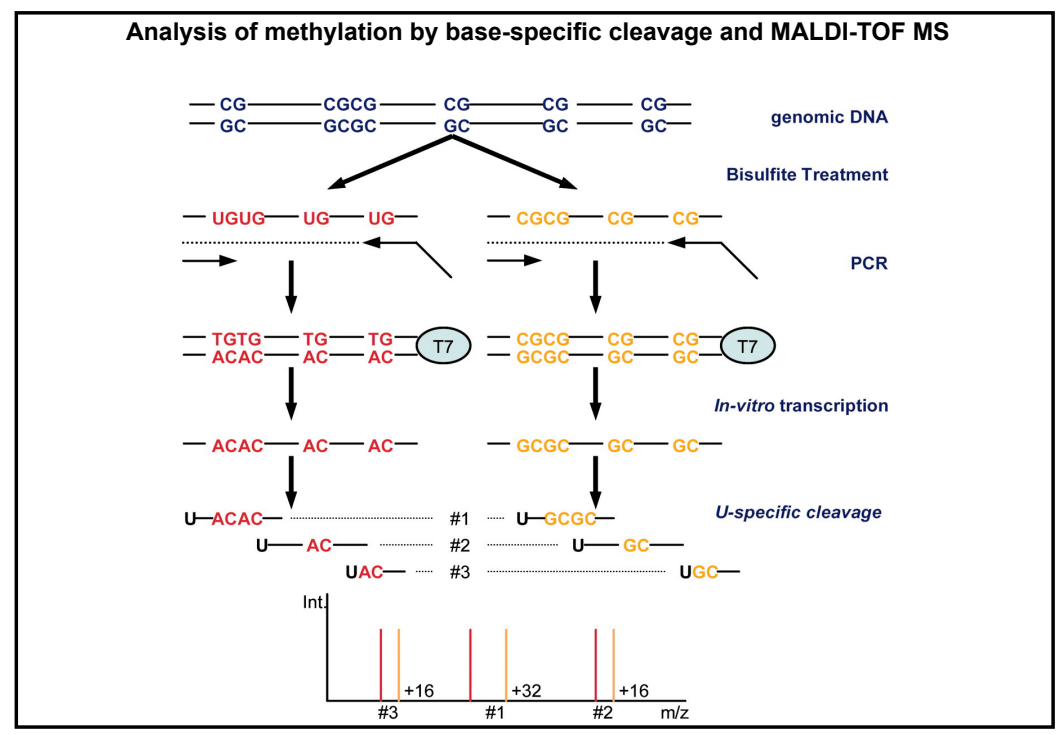

Figura 17. Representación esquemática del análisis de metilación mediante espectrometría de masas MALDITOF. Los oligos utilizados contienen una secuencia promotora de T7. En este ejemplo se representan en amarillo una secuencia metilada y otra no metilada, en rojo. Las variaciones en la secuencia tendrán una repercusión en el peso molecular del fragmento, que serán detectadas mediante espectrometría de masas (124).

Debido a que, como ya se ha comentado anteriormente, el análisis mediante espectrometría de masas del fragmento amplificado presenta un paso intermedio de transcripción in vitro de la polimerasa T7, en todos los oligos diseñados se añadieron las secuencias para el promotor de la polimerasa T7 [5'cagtaatacgactcactatagggagaaggct'3] en el oligo reverse y [5' aggaagagag'3] en el forward. 
Los resultados se analizaron con el software MassCLEAVE (EpiTYPER®, Sequenom, California, EE. UU.), que proporciona tanto los valores de metilación de cada CpG como representaciones gráficas de los mismos. Además, se analizaron de forma paralela parámetros como la conversión completa de las citosinas o la posible presencia de mutaciones en la muestra cuando se compara con la secuencia genómica de referencia. Para ello, se utilizaron paquetes de programación disponibles en Bioconductor, diseñados especialmente para R.

\subsubsection{Diseño de los oligos y Reacción en cadena de la polimerasa $(\mathrm{PCR})$}

En todos los casos, los oligos fueron diseñados utilizando la página web methprimer (http://www.urogene.org/methprimer/index1.html) (198). Debido a que el tratamiento del DNA con bisulfito sódico altera profundamente la secuencia de pares de bases, es necesario comprobar que los oligos diseñados son específicos para la secuencia que queremos analizar. Para ello se utilizó el servidor web http://bisearch.enzim.hu/ $(199,200)$, que permite comprobar la especificidad de los oligos diseñados.

El tamaño de los amplicones fue de aproximadamente 200-400 pb, con una longitud de cada oligo de $24-30 \mathrm{pb}, 50-60^{\circ} \mathrm{C}$ Tan (Temperatura de anillamiento). La reacción se llevó a cabo en un volumen final de $25 \mu \mathrm{L}$ usando el kit de Roche FastStart High Fidelity (Roche Diagnostics, Indianápolis, EE.UU.), y 15 ng de DNA tratado con bisulfito. El modelo de termociclador utilizado fue el Veriti ${ }^{\mathrm{TM}}$ 96-Well Fast ThermalCycler (AppliedBiosystemsInc, California, EE. UU.). 
Tabla 10. A. Reactivos y volúmenes utilizados en las reacciones de cadena de la polimerasa (PCR). B. Programa utilizado para las PCR. Tan: Temperatura específica de primer.

A.

\begin{tabular}{|l|c|}
\hline \multicolumn{1}{|c|}{ Reactivo } & Volumen $(\boldsymbol{\mu L})$ \\
\hline Oligos $(20 \mu \mathrm{M})$ & 2 \\
\hline dNTP $(10 \mu \mathrm{M})$ & 1 \\
\hline Buffer $10 \mathrm{X}$ & 2.5 \\
\hline Taq polimerasa & 0.25 \\
\hline DNA $(5 \mathrm{ng} / \mu \mathrm{l})$ & 3 \\
\hline Agua de alto grado molecular & 16.25 \\
\hline Volumen Total & 25 \\
\hline
\end{tabular}

B.

\begin{tabular}{|c|c|c|}
\hline & $95^{\circ} \mathrm{C}$ & 10 minutos \\
\hline & $195^{\circ} \mathrm{C}$ & 30 segundos \\
\hline 42 ciclos & Tan & 45 segundos \\
\hline & $72^{\circ} \mathrm{C}$ & 45 segundos \\
\hline & $\begin{array}{l}72^{\circ} \mathrm{CC} \\
4^{0} \mathrm{C} \infty\end{array}$ & 10 minutos \\
\hline
\end{tabular}

\subsubsection{Validación de los microarrays}

La validación de los datos generados por los microarrays se llevó a cabo mediante el análisis de los niveles de metilación en citosinas localizadas en sitios de corte HpaII, que generaron las señales de HELP, previo tratamiento del DNA con bisulfito sódico seguido de MassArray.

Los oligos se diseñaron en regiones HELP de aproximadamente 800 pares de bases de longitud que no presentaban ninguna otra diana para HpaII en al menos 2000 pares de bases de distancia.

La secuencia de los cebadores (primers) diseñados para la validación técnica se muestra en la tabla 11. 
Tabla 11. Oligos utilizados en los experimentos de PCR para la validación técnica. Se añadieron las secuencias "aggaagagag" en la posición 5' de los oligos forward y también en la posición 5' se añadió la secuencia "cagtaatacgactcactatagggagaaggct" en el caso de los oligos "reverse".Tan se expresa en ${ }^{0} \mathrm{C}$

\begin{tabular}{|c|c|c|c|c|c|}
\hline Nombre & Genoma & Orientación & PCR primer & Tan & Posición cromosómica \\
\hline \multirow{2}{*}{ TFCH_1.1 } & \multirow{2}{*}{ HG18 } & Forward & TTTTTAGTTGGGTTTTTTGAAAAGT & \multirow{2}{*}{59} & \multirow{2}{*}{ chr2: $330890-331094$} \\
\hline & & Reverse & ACACACAAAAAATTTTAAAATCACTATCA & & \\
\hline \multirow{2}{*}{ TECH_1.2 } & \multirow{2}{*}{ HG18 } & Forward & GGTTGATTTTGAGTGTAGGGATTAA & \multirow{2}{*}{58} & \multirow{2}{*}{ chr2: $331250-331539$} \\
\hline & & Reverse & AAACTTCTCTAAAAAAATAAAAAACTAC & & \\
\hline \multirow{2}{*}{ TECH_2.1 } & \multirow{2}{*}{ HG18 } & Forward & TAGGATTTGGTAGGGAGTGAATTTA & \multirow{2}{*}{59} & \multirow{2}{*}{ chr2: $12102733-12102956$} \\
\hline & & Reverse & AAACCTTCAACACTTAACTCAAAAC & & \\
\hline \multirow{2}{*}{ TECH_2.2 } & \multirow{2}{*}{ HG18 } & Forward & TTTTAATTGAGAGAATTTTGAGTAGT & \multirow{2}{*}{56} & \multirow{2}{*}{ chr2: 12103439-12103593 } \\
\hline & & Reverse & TATAAAAACTACATTACCTACCAAACTATA & & \\
\hline \multirow{2}{*}{ TECH_3.1 } & \multirow{2}{*}{ HG18 } & Forward & TTATTTGTAATGTTAGTTTGAAAATGTTA & \multirow{2}{*}{58} & \multirow{2}{*}{ chr3: $187134916-187135215$} \\
\hline & & Reverse & TATCTTTTTATATTCCTTAATTTTAACTCC & & \\
\hline \multirow{2}{*}{ TECH_3.2 } & \multirow{2}{*}{ HG18 } & Forward & AATTGTGATTTAAAGGTTAGGAGTGTT & \multirow{2}{*}{60} & \multirow{2}{*}{ chr3: $187135612-187135757$} \\
\hline & & Reverse & CTAACCAAACCACTTTCAAAAATAAA & & \\
\hline \multirow{2}{*}{ TECH_6.1 } & \multirow{2}{*}{ HG18 } & Forward & TTAGGGTTTGGGTGTTGATTATTAT & \multirow{2}{*}{60} & \multirow{2}{*}{ chr6: $50916498-50916749$} \\
\hline & & Reverse & AACAACCCTCTAАСТTCTTТCТСТАС & & \\
\hline \multirow{2}{*}{ TECH_6.2 } & \multirow{2}{*}{ HG18 } & Forward & TTTATTTGAATTTTTATAGTGGGTTTT & \multirow{2}{*}{59} & \multirow{2}{*}{ chr6: $50807822-50808116$} \\
\hline & & Reverse & TTAAACAAATAATTTTTCAACCTTCC & & \\
\hline \multirow{2}{*}{ TECH_12.1 } & \multirow{2}{*}{ HG18 } & Forward & TAGATGGTGATATTATTGATGGGTTT & 60 & $\operatorname{chr} 12 \cdot 101392870-101393049$ \\
\hline & & Reverse & CAAACAAAAAATTAACTCCCCTTAA & 60 & Cinl 12.1015920/0-101595049 \\
\hline & HG18 & Forward & AGAGGTTTAGGATGGTTGTTAGATA & 60 & $\operatorname{chr} 12 \cdot 101393425-101393658$ \\
\hline 1ECH_12.2 & Huls & Reverse & ACCТАСТСАССТТСАССАACТСТАС & 60 & (cnI 12.101593425-101595050 \\
\hline & HG18 & Forward & TGATTTATTTAAGGGTTTTGATGAT & 58 & chr13:112517416-112517865 \\
\hline 1ECH_15.1 & HuI & Reverse & TTATTTCATCAATAAAAAAAACATCTC & 58 & (cnI15.11251/410-11251/805 \\
\hline TECH & HG18 & Forward & TTTGTGAATAGATGAGTAGTTTGAGG & 60 & \\
\hline IEC & HUI8 & Reverse & ССССТТАСТТТАТААСТАAАТТСТССА & 60 & \\
\hline
\end{tabular}

\section{La secuencia de todos los oligos utilizados en la validación biológica se detallan en}

\section{la siguiente tabla 12 .}

Tabla 12. Oligos utilizados en los experimentos de PCR para la validación del gen CYP26A1. Ya que estos oligos fueron utilizados para el MassArray, se añadieron las secuencias "aggaagagag" en la posición 5' de los oligos forward y también en la posición 5' se añadió "cagtaatacgactcactatagggagaaggct" en el caso de los oligos reverse. Tan se expresa en ${ }^{\circ} \mathrm{C}$.

\begin{tabular}{|c|c|c|c|c|c|}
\hline Nombre & Genoma & Orientación & PCR primer & Tan & Posición cromosómica \\
\hline \multirow{2}{*}{ CYP26A1.1 } & \multirow{2}{*}{ IIG18 } & Forward & TTTTTTTAAGAAGTGGTTAGTAGAATT & \multirow{2}{*}{57} & \multirow{2}{*}{ chr10: 94818917-94819108 } \\
\hline & & Reverse & ACCCTAACCTAACTTTAAACCATAAA & & \\
\hline \multirow{2}{*}{ CYP26A1.2 } & \multirow{2}{*}{ HG18 } & Forward & TTTTTGTTTTAATTTTTGTTTTTGTG & \multirow{2}{*}{58} & \multirow{2}{*}{ chr10: $94820009-94820244$} \\
\hline & & Reverse & СТААСТСАССССТТАТАТССААСТАС & & \\
\hline \multirow{2}{*}{ CYP26A1.3 } & \multirow{2}{*}{ HG18 } & Forward & GGGTGTTATATGTAGAGGGAATAGTAG & \multirow{2}{*}{56} & \multirow{2}{*}{ chr10: $948210076-94821200$} \\
\hline & & Reverse & TAAACTAAAATCACAACAAAAAAATC & & \\
\hline \multirow{2}{*}{ CYP26A1.4 } & \multirow{2}{*}{ HG18 } & Forward & TTTATTGGTTTTTTATTTTTAGGTGT & \multirow{2}{*}{56} & \multirow{2}{*}{ chr10: $94832969-94833259$} \\
\hline & & Reverse & ССТТСТААААСТТСАТАААТССТААС & & \\
\hline \multirow{2}{*}{ CYP26A1.5 } & \multirow{2}{*}{ HG18 } & Forward & GTATTTGGAAATGGAAAGTTAGTGA & \multirow{2}{*}{57} & \multirow{2}{*}{ chr10: $94833233-94833406$} \\
\hline & & Reverse & ССССАТССАAАATATACTAАACTC & & \\
\hline
\end{tabular}


sResultados 


\subsection{Características de la población}

Para este estudio se seleccionó una población adulta (media de edad en controles 49 años, media de edad en alérgicos 41 , valor de $\mathrm{p}=0,11$ ), con igual representación de hombres y mujeres.

La población de pacientes presentaba alergia a los ácaros del polvo y síntomas de asma moderada o grave. La media de los valores de IgE en suero en este grupo fue de $254 \mathrm{KU} / \mathrm{L}$, mientras que en el grupo control fue de 48,5 KU/L (valor de $\mathrm{p}=0,002$ )

\subsection{Aislamiento de Células B}

Los patrones epigenéticos son una característica intrínseca del tipo celular, pudiendo variar incluso dentro del momento del ciclo celular en el que ésta se encuentre (126). Por tanto, un factor importante en este estudio fue conseguir una población celular lo más homogénea y pura posible.

Con el fin de comprobar la pureza de la población celular aislada mediante selección inmunomagnética, se recurrió a la citometría de flujo. A pesar de que para la selección celular se utilizó el epítopo CD19, característico de los linfocitos B maduros, para este experimento se empleó el CD20, un marcador también característico de linfocitos B maduros. Este marcador, característico de linfocitos B, no se expresa en todos los casos simultáneamente con el CD19, aunque el 
solapamiento entre ambos es lo bastante amplio como para permitir llevar a cabo este tipo de experimento.

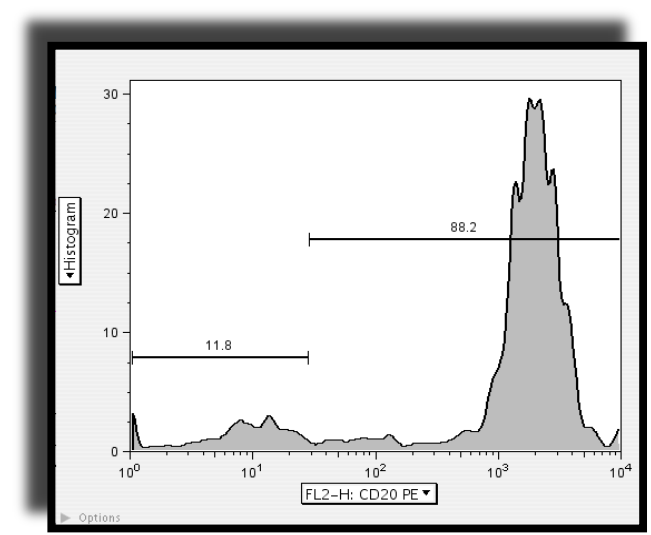

Figura 18. Porcentaje de células $\mathrm{B} \quad \mathrm{CD}_{2} 0^{+}$obtenidas mediante citometría de flujo.

El análisis de los datos obtenidos (figura 18) demuestran que aproximadamente el 90\% de las células vivas eran linfocitos $\mathrm{CD}_{20}{ }^{+}$, validando la extracción magnética como método de aislamiento celular.

\subsection{Estudio global de los patrones de metilación}

\subsubsection{HELP assay}

Mediante electroforesis en gel de agarosa al 1\% se visualizaron $10 \mu \mathrm{L}$ de la digestión de $1 \mu$ g de DNA de cada muestra con HpaII o su esquizómera, MspI. Como se puede ver en la figura 19, el DNA procedente del tratamiento con HpaII se mantiene con alto tamaño molecular, mientras que el DNA procedente de la digestión con MspI presenta un rango de tamaños amplio y de menor tamaño molecular. 


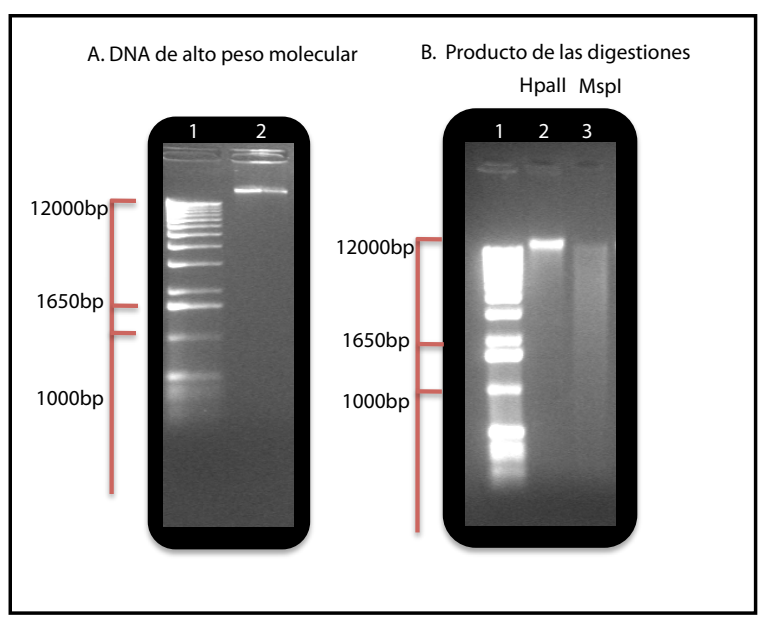

Figura 19. Imagen de dos geles de agarosa al $1 \%$ teñidos con bromuro de etidio. A 1 . Marcador de tamaño molecular 2. Banda de DNA genómico de una de las muestras. B 1. Marcador de tamaño molecular 2. Producto de la digestión de DNA con HpaII (que se mantiene en forma de alto tamaño molecular) 3. Producto de la digestión con MspI (que presenta una digestión completa del DNA)

La población representada por MspI sería la misma que la representada por HpaII si ninguno de los sitios 5'-CCGG-'3 estuvieran metilados. Sin embargo, se sabe que el 55\%-70\% del total de estos sitios se encuentran metilados en genomas animales $(201,202)$, por lo que la población de HpaII es sólo una representación del total de la población de MspI. La población genómica de bajo tamaño molecular representada tras la digestión con HpaII es, por lo tanto, rica en fragmentos hipometilados.

En el HELP assay, ambas poblaciones (HpaII y MspI) sufren una selección de tamaño, debido a las condiciones de ligación y posterior amplificación mediante PCR, por lo que se puede ver un rango de tamaños característico, que va desde las 2000 pares de bases en los fragmentos más grandes, hasta 50 las pb. Tras la PCR, $10 \mu \mathrm{L}$ de cada muestra se visualizaron en un gel de agarosa al 1\% teñido con bromuro de etidio (Figura 20. A) 


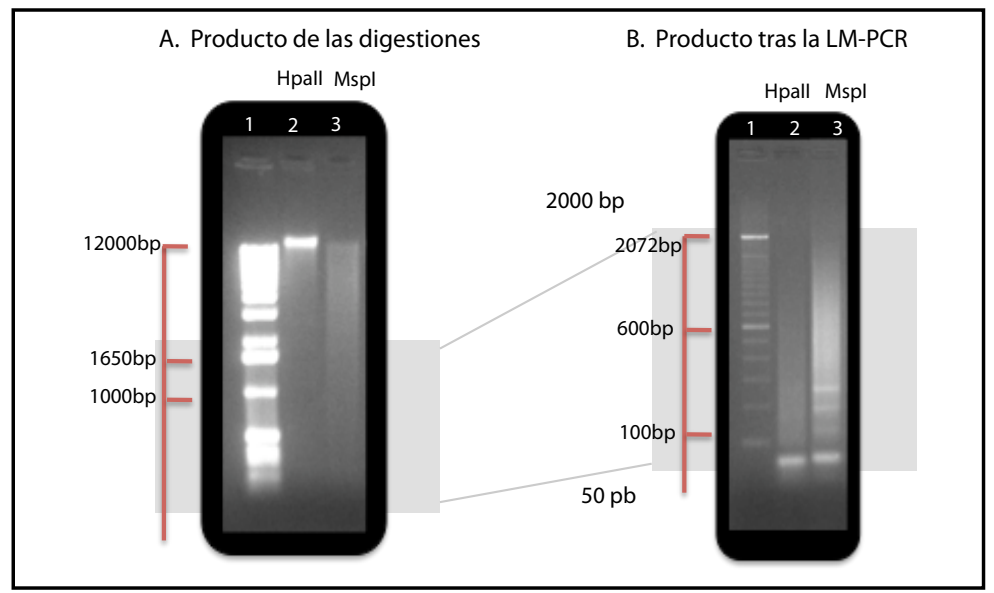

Figura 20. Imagen de dos geles de agarosa al 1\% teñidos con bromuro de etidio A1. Marcador de tamaño molecular. 2. Producto de la digestión con HpaII 3. Producto de la digestión con MspI. B 1. Marcador de tamaño molecular. Tras la generación de las librerías y amplificación de las mismas (LM-PCR), se puede ver el producto de 2.HpaII y 3.MspI

En la figura 20.B se muestra las poblaciones obtenidas tras el proceso de digestión con HpaII y MspI, generación de las respectivas librerías y posterior amplificación mediante PCR. Estas librerías presentan un tamaño que varía desde los 50 hasta las $2000 \mathrm{pb}$. Las bandas que se observan en MspI corresponden a secuencias ALU, elementos repetitivos y móviles, muy abundantes en el genoma de los primates, que permanecen metilados en el genoma y tienen una longitud que oscila entre las 100 y las $400 \mathrm{pb}$.

\subsubsection{Control de calidad}

Tras la hibridación de las muestras en las matrices y la obtención de los valores de intensidad para cada canal (HpaII o MspI), se realizó un control de calidad de los mismos. Para ello, se seleccionaron 5000 loci al azar para MspI, HpaII y se analizó la proporción (HpaII/MspI) en cada muestra. 
Antes de poder considerar la variabilidad biológica entre las muestras, fue necesario controlar la variabilidad técnica, inherente a cualquier tipo de experimento. Así, se buscaron artefactos espaciales mediante la comparación de la media de las ratios de las señales de intensidad en función de la posición dentro del array. Cada plataforma se dividió en 25 sectores, de los que se tomaron medidas de intensidad de las sondas localizadas en cada sector, para después comparar la distribución entre distintos sectores. La plataforma que se utilizó para llevar a cabo las micromatrices presenta miles de "sondas" o pruebas de secuencia aleatoria con una longitud de 50 nucleótidos, que se utilizaron como medida para controlar la hibridación inespecífica y la fluorescencia de fondo. Por diseño, estas sondas están distribuidas al azar en la micromatriz.

En los casos en los que la hibridación fue adecuada, se observó una relativa uniformidad en la distribución de los ratios en todos los sectores (Muestra 1, Figura 21), mientras que, en aquellos casos en los que la hibridación fue deficiente, se pudo observar el efecto de los artefactos experimentales debido a problemas con la hibridación mediante patrones de colores no uniformes que oscilaron del rojo al verde intenso (Muestras 2 y 3, Figura 21). En los casos que se muestran en

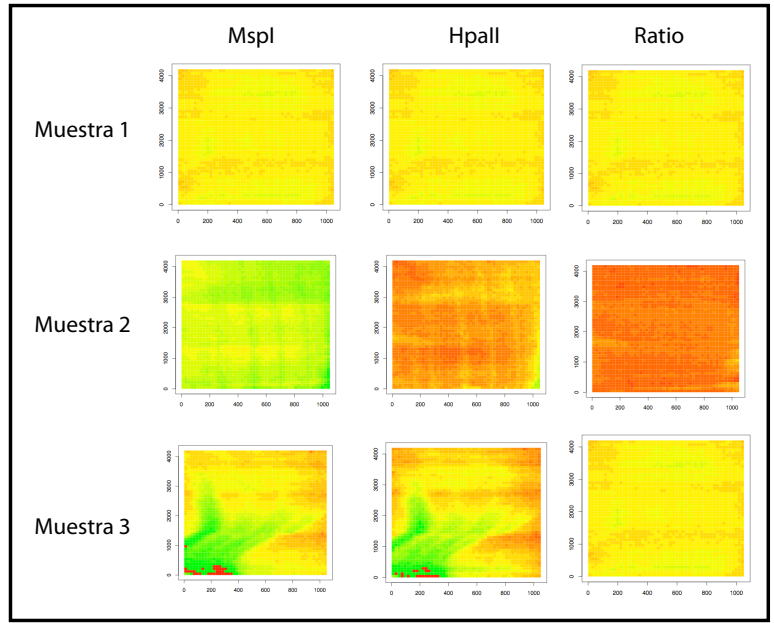

Figura 21. Control de calidad realizado en tres muestras diferentes. Se representan los tres canales, MspI, HpaII y Ratio (LogHpaII/MspI) para cada muestra. La muestra 1 es el resultado de un control de calidad adecuado debido a una buena hibridación. Los artefactos espaciales debidos a una mala hibriadación se pueden observar en las muestras 2 y 3 El color verde revela señales menos intensas que la media de intensidades de la matriz, mientras que el color rojo denota intensidades suneriores a la media. 
la figura 21, las dos muestras que no superaron el control de calidad se volvieron a hibridar en una nueva micromatriz.

Como se ha comentado anteriormente, la intensidad de fondo (ruido) de cada micromatriz se cuantificó mediante sondas distribuidas de forma aleatoria en la matriz. En cada caso se definió una población de fragmentos "fallidos" cuando las señales de intensidad de HpaII o MspI fueron indistinguibles del valor definido para el ruido. Estos fragmentos, que supusieron aproximadamente un 10-20\% del total de las sondas y una pequeña fracción de los HTF (de sus siglas en inglés HpaII Tiny Fragments), fueron eliminados del análisis. En aquellos casos en los que sólo se vió afectada la señal de HpaII, se asumió que podía deberse a un estado concreto de metilación de ese locus en particular, y no se eliminó del análisis.

\subsubsection{Normalización de cuantiles}

Con el fin de evitar posibles sesgos producidos por la longitud de los fragmentos obtenidos tras la PCR, se realizó una normalización de cuantiles. El objetivo de esta normalización fue homogeneizar las señales de intensidad según la longitud del fragmento, mejorando las posibles comparaciones inter e intraensayo (ver Figura 22) .

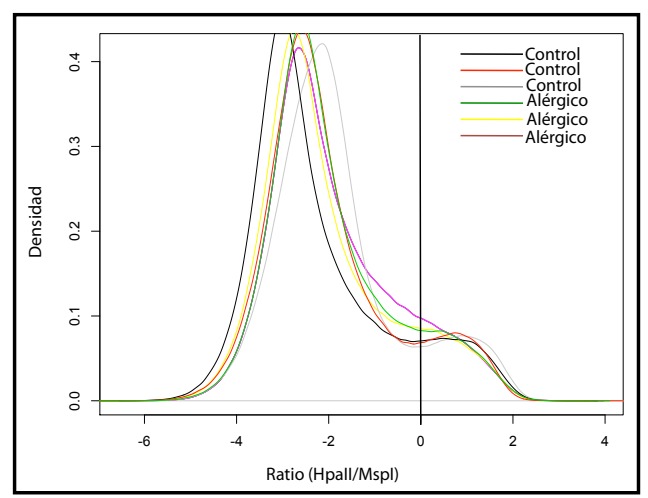

Figura 22. Gráfico de densidades tras la normalización de cuantiles. En el eje de ordenadas se representa la densidad frente a la ratio HpaII/MspI para controles y alérgicos. 


\subsubsection{Gráfico de densidades}

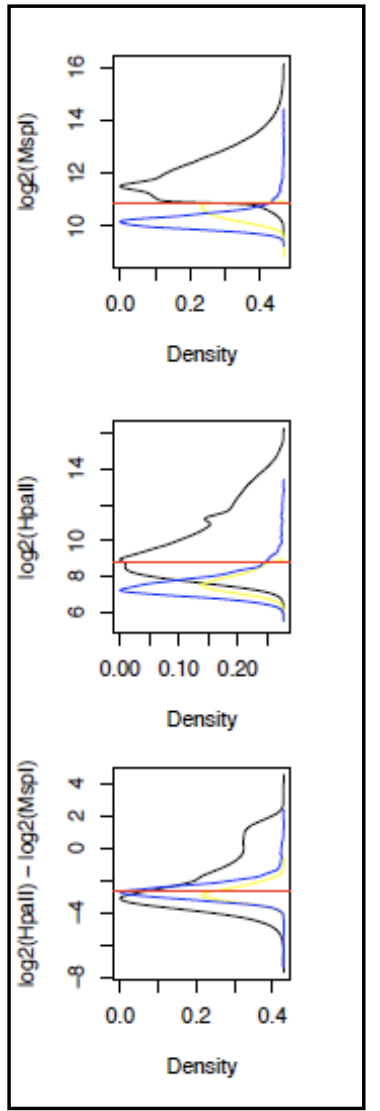

En el gráfico de densidades (Figura 23) se puede observar la distribución de densidades de los fragmentos frente el valor logarítmico de MspI, HpaII y la ratio (HpaII/MspI).

La línea horizontal roja representa el punto de corte a partir del cual cualquier fragmento con un valor logarítmico menor pasa a considerarse como no válido. Este valor se calcula como $\pm 2,5$ unidades MAD (Median Absolute Deviation) de la mediana de las intensidades de las sondas aleatorias. En azul, se representan los valores de las sondas de 50 nucleótidos repartidas de forma aleatoria en el array. En amarillo se representan los valores descartados para el estudio por presentar valores de intensidad menores de los esperados y en negro la distribución de densidades de los fragmentos válidos para el estudio.

Figura 23.Gráficos de densidades de las intensidades obtenidas en MspI, HpaII y la ratio (HpaII/MspI) respectivamente. En el eje de ordenadas se representan los valores de intensidad de los fragmentos. En el eje de abscisas, la densidad.

En el caso del gráfico de densidades para la proporción (HpaII/MspI), la línea roja representa el punto de corte entre fragmentos metilados (valores negativos) y no metilados (valores positivos).

Cuando se representa el logaritmo de las intensidades para cada canal (MspI, HpaII o Ratio (HpaII/MspI)(figuras 24, 25, y 26) frente al tamaño de los fragmentos, se 
puede observar la distribución característica de cada grupo. En todos los casos, la línea roja horizontal representa el punto de corte para los datos que serán eliminados. En amarillo se representan éstos datos, que fueron descartados en todos los casos, excepto para HpaII, donde podrían estar hipometilados.

En la representación de los fragmentos amplificados en HpaII se puede observar una población de bajo tamaño molecular cuyas intensidades son bajas, representando una población de fragmentos hipermetilados en la muestra.

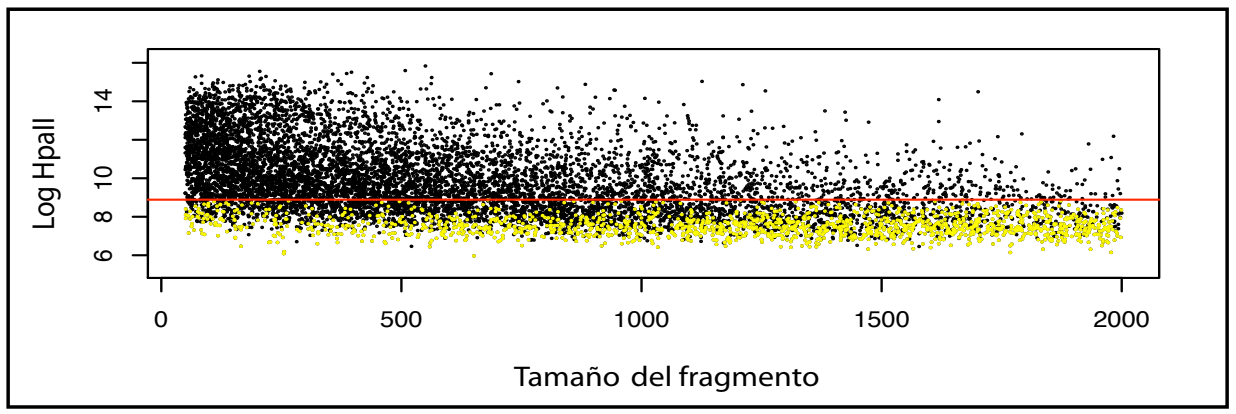

Figura 24. Representación gráfica de intensidad frente a longitud en fragmentos digeridos con HpaII. En el eje de ordenadas se representa el logaritmo de la intensidad de HpaII frente a la longitud de los fragmentos, en el eje de abscisas. En este caso la línea roja simboliza el punto de corte de fragmentos que están metilados. Como se puede observar en la figura, HpaII presenta una densidad mayor de fragmentos de pequeño tamaño y una gran intensidad. Este patrón es característico del canal de HpaII.

La población de MspI presenta logaritmos de intensidad más bajos en fragmentos de menor longitud, con una población de fragmentos alrededor de las 500-600 pb que presentan los mayores valores de intensidad. 


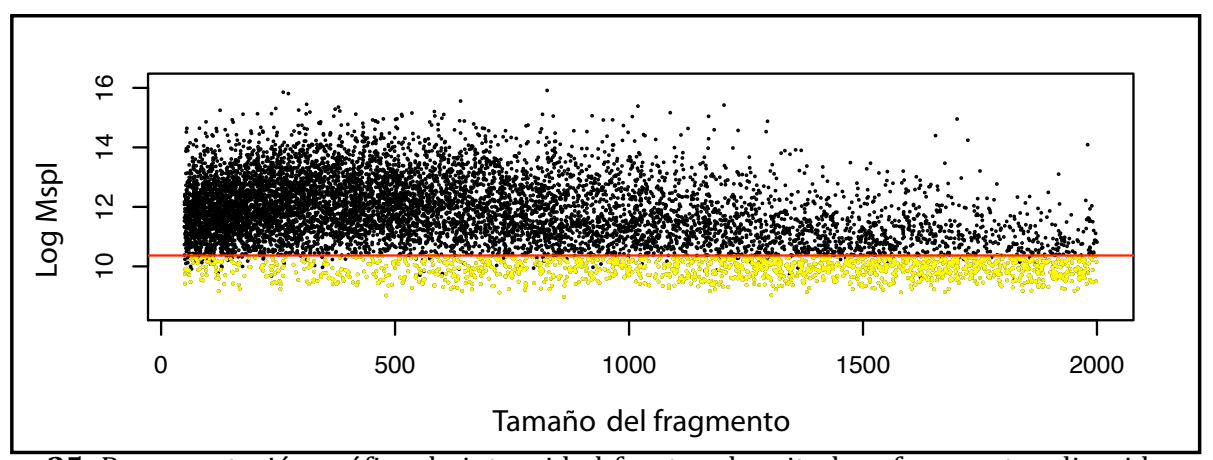

Figura 25. Representación gráfica de intensidad frente a longitud en fragmentos digeridos con $M s p I$. En el eje de ordenadas se representa el logaritmo de la intensidad de MspI frente a la longitud de los fragmentos (en pares de bases), en el eje de abscisas. En este caso la línea roja simboliza el punto de corte de fragmentos que serán eliminados del estudio Como se puede observar en la figura, MspI presenta una densidad mayor de fragmentos alrededor de las 500 pares de bases y una gran intensidad. Este patrón es característico del canal de MspI.

Cuando se representa la media normalizada de la ratio (HpaII/MspI) como un diagrama de densidades se pueden ver dos poblaciones bien diferenciadas. Una de ellas, mayoritaria, con valores de ratio bajos, que representa la población hipermetilada del genoma. La población de fragmentos con ratios elevadas es la que, por definición, está hipometilada.

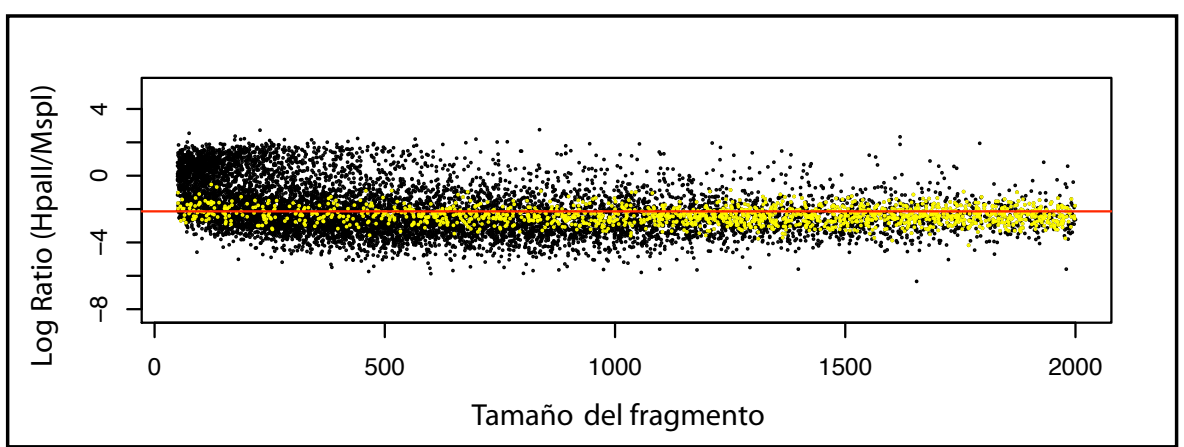

Figura 26. Representación gráfica de intensidad frente al logaritmo del ratio (HpaII/MspI). En el eje de ordenadas se representa el logaritmo de la intensidad del ratio frente a la longitud de los fragmentos (en pares de bases), en el eje de abscisas. En este caso la línea roja simboliza el punto de corte entre fragmentos que son considerados como hipometilados (por encima de la línea) e hipermetilados (por debajo de la línea). 


\subsubsection{Dendogramas}

Con el fin de analizar las relaciones de semejanza o diferencia entre las muestras a nivel global, se llevó a cabo un análisis de pares usando el coeficiente de correlación de Pearson, una medida de correlación lineal entre dos variables normales, entre todas las posibles combinaciones de pares. Además, se realizó un análisis no supervisado y un análisis de grupos, usando la varianza mínima de Wards y una matriz de distancia euclidiana. De esta forma, aparece una visualización de los datos que permite una rápida interpretación de los mismos, conocida como dendograma.

En este estudio, se puede observar una clara tendencia del grupo de controles a agruparse, con valores de semejanza muy altos (valores de R cercanos a 1), lo que sugiere que los patrones epigenéticos de los linfocitos B de individuos no atópicos y sin asma presentan ciertas marcas epigenéticas que las caracteriza y diferencia de aquellos que presentan los pacientes con alergia a los ácaros. 


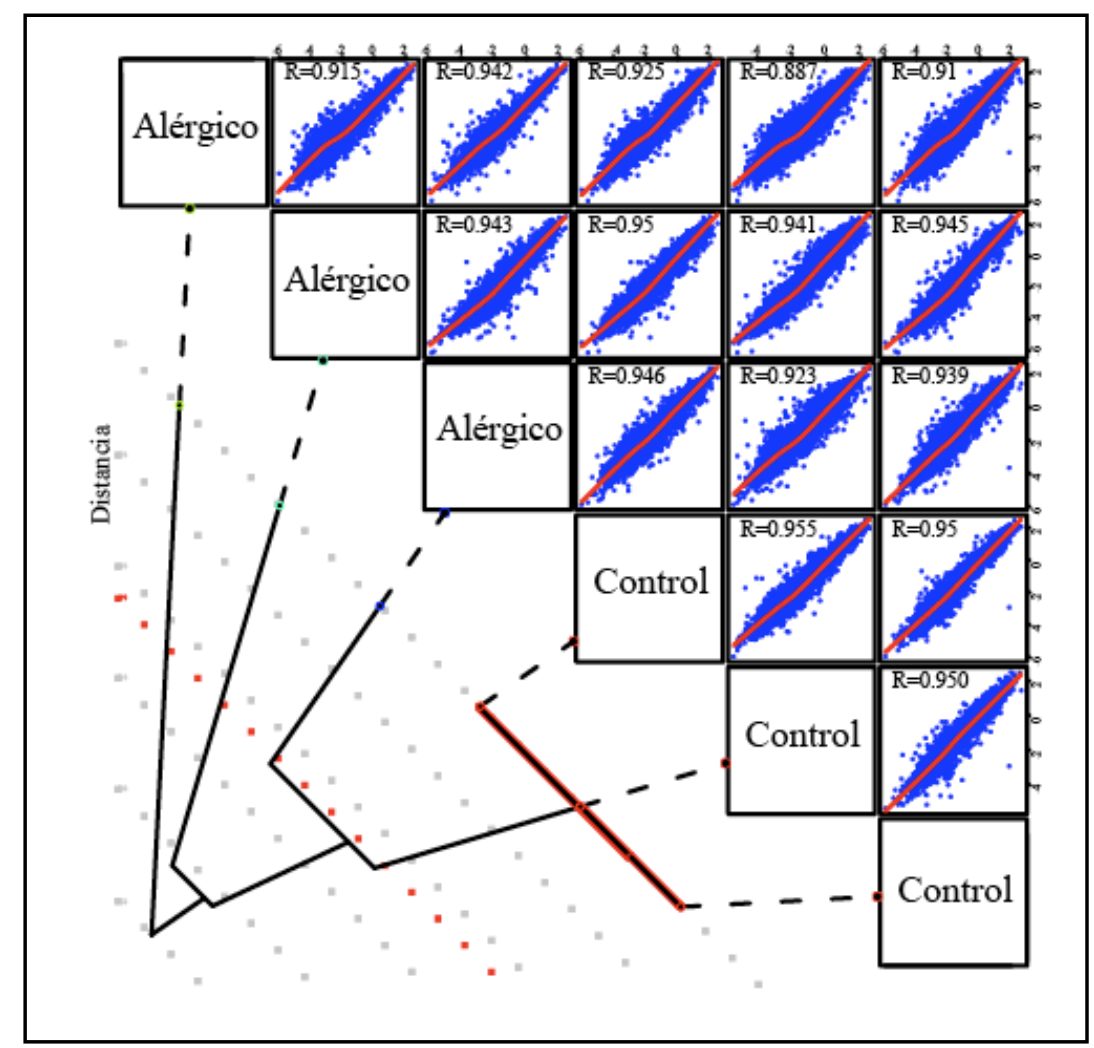

Figura 27. Unión de dos análisis, formando lo que se conoce como dendograma, un análisis no supervisado y un análisis de pares usando la correlación de Pearson. Las tres muestras de controles y las tres de pacientes alérgicos se compararon usando la mínima varianza de Ward y las distancias entre matrices fueron calculadas como la distancia euclidiana entre las ratios de los mismos. La línea roja punteada representa el punto de corte de la distancia euclidiana usada para separar los diferentes grupos de muestras. Los valores de correlación de Pearson se muestran en la parte superior, mientras que los puntos azules sirven como representación visual de las diferencias entre muestras.

\subsubsection{Visualización de los datos}

La visualización de los datos a nivel local se realizó usando las posiciones cromosómicas de cada locus. Se generaron archivos con formato BED, que se visualizaron usando el UCSC Genome Browser (http://genome.ucsc.edu/) (203). Este tipo de visualización permitió pasar de un análisis global a uno más específico, cromosoma a cromosoma, de cada una de las muestras, con 
información concreta de los genes en los que se detectaron las diferencias de metilación y la magnitud de los mismos.

Para cada muestra se generó un archivo BED con los valores de intensidad de cada locus concreto, para cada cromosoma. En todos los casos se normalizaron los valores a cero, lo que permitió interpretar como hipometilado aquellos valores mayores de cero (por encima de la línea de corte) y los valores menores que cero como hipermetilados (por debajo de esta línea) (Figura 28).

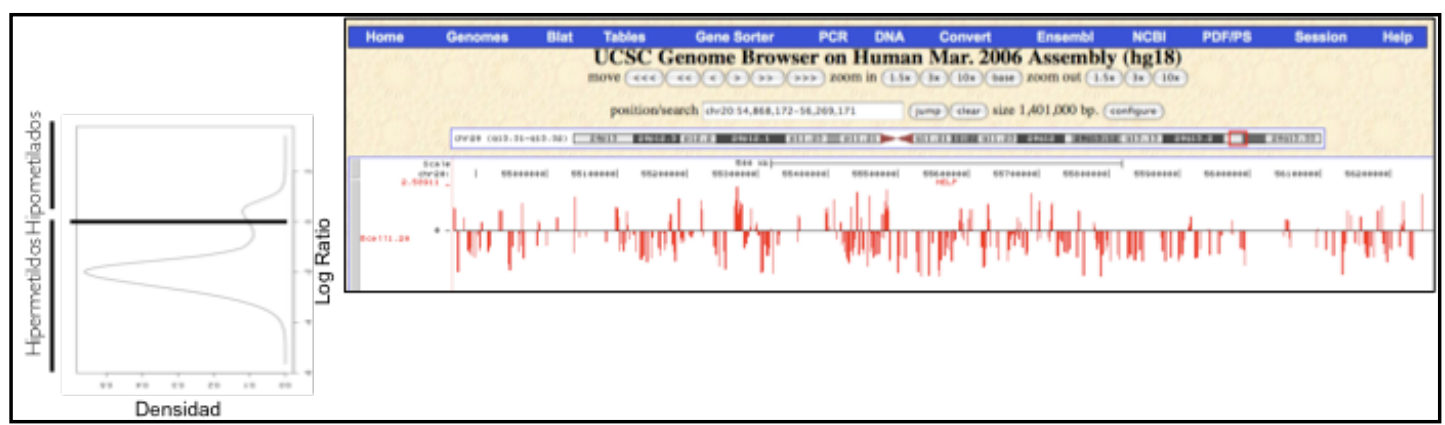

Figura 28. Visualización de los datos de HELP en el Genome Browser. En esta imagen se muestran los datos obtenidos por HELP de una pequeña parte del brazo largo del cromosoma 10. Por definición, los fragmentos hipometilados son los que presentan una ratio (HpaII/MspI) positiva, como se puede ver en la figura de la izquierda. Esto se transforma, en el Genome Browser, en que los fragmentos que están por encima de la línea son los hipometilados, mientras que los fragmentos hipermetilados, con una ratio negativa, se encuentran por debajo de esta línea.

\subsubsection{HeatMap}

En la figura 29 se puede ver una representación gráfica de los datos en una matriz en dos dimensiones que también incluye un análisis de grupos, que se conoce como Heatmap. Cada columna representa una muestra y en filas se muestran los valores de cada locus, representados en una escala de colores. Esta escala de colores, que va desde el rojo al blanco, es proporcional a los valores que 
representan, con color rojo los valores negativos (loci que están hipermetilados) y blanco los valores más altos (loci que están hipometliados)

En este análisis supervisado se representan 1000 loci escogidos aleatoriamente de un total de aproximadamente 1500 fragmentos que presentaban una diferencia mayor de 1,4 unidades logarítmicas de ratio entre controles y alérgicos y un valor de $\mathrm{p}$ estadísticamente significativo $(\mathrm{p}<0,05)$.

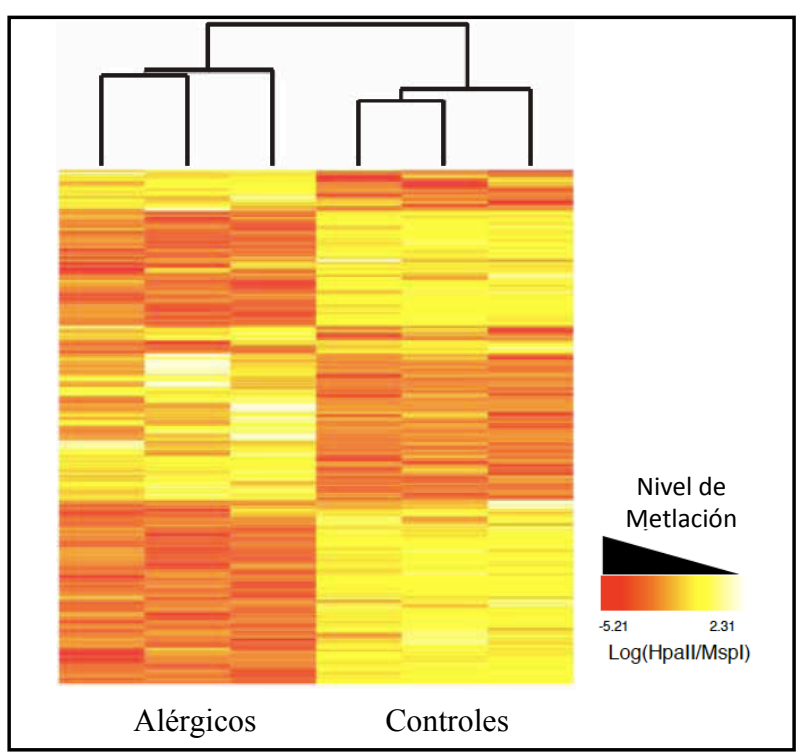

Figura 29. Análisis supervisado jerárquico de dos dimensiones representado por un Heatmap. Se representan 1000 loci escogidos al azar de entre aquellos que presentaban una diferencia en el Log Ratio mayor de 1,4 unidades entre alérgicos y controles y un valor de $p$ menor de 0,05. Las muestras se representan en las columnas, los diferentes loci en filas

\subsubsection{Volcano}

Tras calcular las diferencias entre ambos grupos (alérgicos y controles) con un estadístico de contraste como el valor de p y compararlo con el valor de la diferencia de las ratios para ese locus concreto, se obtiene una representación de los datos que se conoce como "Volcano Plot" (Figura 30). En el eje de abscisas se representan los valores de las diferencias de intensidad para un locus concreto 
como la diferencia en la ratio (HpaII/MspI) entre alérgicos y controles. En el eje de ordenadas se representan los valores de $\mathrm{p}$ de un t-test de Student entre ambos grupos. En este tipo de representaciones se usa una escala logarítmica invertida, lo que significa que los valores más significativos de p se encuentran más arriba en el eje de ordenadas.

Esta representación permite ordenar los cambios según su impacto biológico y estadístico: el eje de abscisas representa el impacto biológico del cambio; el eje de las ordenadas proporciona una idea de la fiabilidad del cambio.

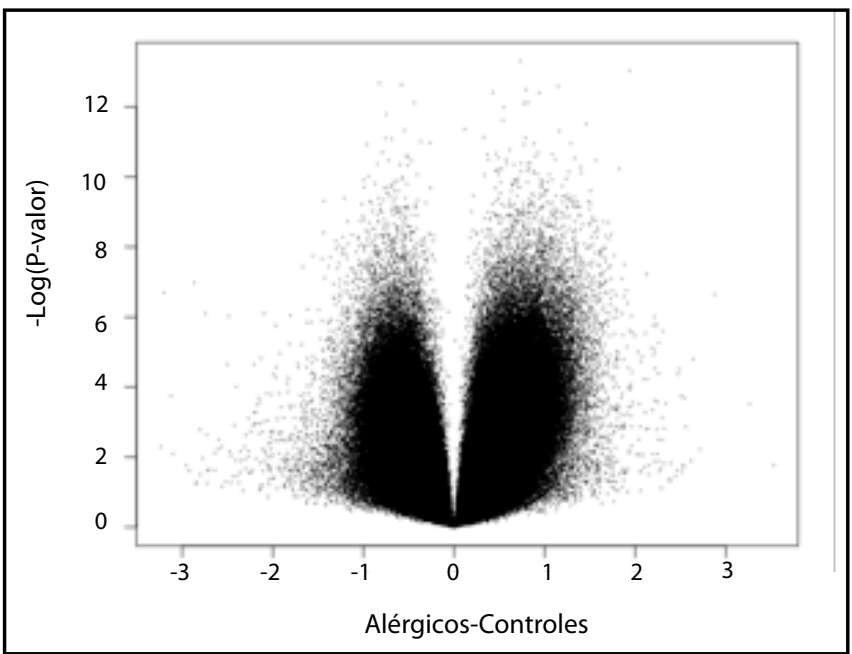

Figura 30. Volcano-Plot. En el eje de ordenadas se representa el valor negativo del logaritmo del estadístico de contraste valor de valor de $\mathrm{p}$, mientras que en el eje de abscisas se representa la diferencia de intensidades (ratio HpaII/MspI) entre alérgicos y controles. 


\subsubsection{P-values Plot}

Cuando se representan los valores de un estadístico de contraste, como el valor de $\mathrm{p}$, frente a la frecuencia con la que este valor aparece, se obtiene una representación muy intuitiva de la magnitud de las diferencias entre los grupos a comparar. Este tipo de gráficos, conocido como "P-value Plot" proporciona información sobre la frecuencia en la que aparecen diferencias altamente significativas en la muestra (Figura 31).

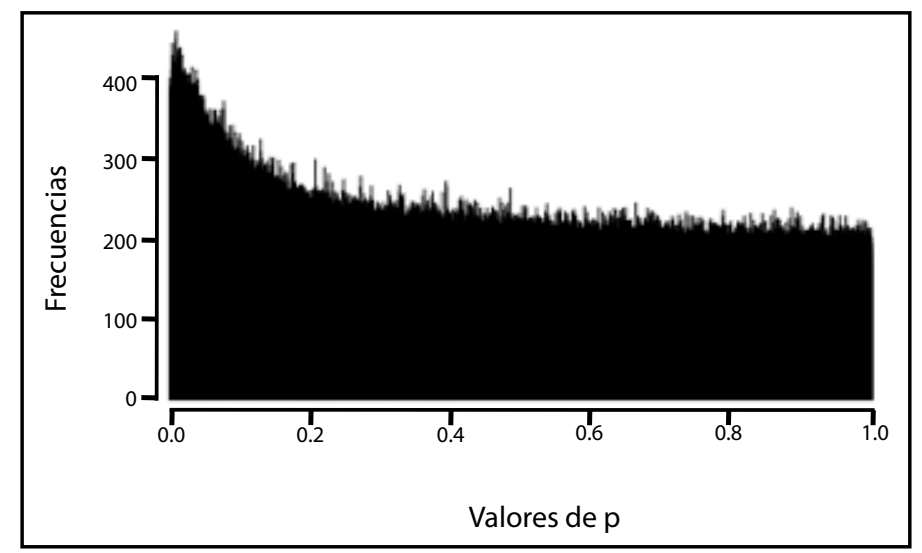

Figura 31. P-values plot. En el eje de abscisas se representan los valores del estadístico de contraste (valor de p) frente a la frecuencia con la que éste aparece.

\subsubsection{Ingenuity Pathway Analysis}

El Ingenuity Pathway Analisys (IPA ${ }^{\mathrm{TM}}$ ) es un programa de Ingenuity Systems disponible a través de la web, previo pago. Permite analizar simultáneamente múltiples conjuntos de datos biológicos y genómicos, ofreciendo una visión rápida y biológicamente significativa del conjunto de datos a analizar, lo que constituye una poderosa herramienta para la generación de hipótesis biológicas. 
Para este estudio se eligieron más de 100 genes, incluyendo la región promotora ( \pm 1000 pares de bases antes del sitio de inicio de transcripción) que presentaran metilación de forma diferencial entre controles y pacientes alérgicos. En este caso, se eligió el valor arbitrario de 1,5 unidades logarítmicas de diferencia en la ratio HpaII/MspI entre casos y controles. En este tipo de estudios, es el investigador el que, a priori, selecciona los genes que son relevantes para cada caso concreto. En nuestro caso, para evitar cualquier idea preconcebida de los datos, se eligieron aquellos genes que presentaban mayores diferencias entre ambos grupos.

El análisis funcional que realizamos nos permitió identificar los procesos biológicos asociados a los genes que presentaban distintos niveles de metilación diferencial entre pacientes y controles. Se empleó el análisis denominado Canonical Pathways para estudiar en qué cascadas de transmisión de señales intracelulares se encontraban involucrados estos genes. En este tipo de análisis se comparan los valores esperados frente a los observados para cada cascada de transmisión de señales y a esta ratio se le añade un estadístico de contraste como el valor de p, con el objetivo de comprobar si la asociación es debida al azar o no. En la tabla 13 se muestra el resultado de este análisis con las 5 cascadas de transmisión de señales que resultaron significativas tras este análisis. 
Tabla 13. Resultados del análisis llevado a cabo mediante IPA. Se muestran los valores de las cascadas de transmisión de señales intracelulares que resultaron significativas. La ratio se calculó teniendo en cuenta el número de genes observados en los datos del estudio frente el total de genes involucrados en esa determinada ruta celular

\begin{tabular}{|c|c|c|c|c|c|}
\hline \multirow[t]{2}{*}{ ruta celular } & \multirow[b]{2}{*}{$\begin{array}{c}\text { Numero de moléculas } \\
\text { encontradas }\end{array}$} & \multirow[b]{2}{*}{$\begin{array}{c}\text { Símbolo según Entrez } \\
\text { Gene }\end{array}$} & \multirow[b]{2}{*}{ Valor de p } & \multirow[b]{2}{*}{-Log (p-valor) } & \multirow[b]{2}{*}{ Ratio } \\
\hline & & & & & \\
\hline GM-CSF & 10 & $\begin{array}{l}\text { AKT1, CAMK2B, } \\
\text { ELK1, PIK3R1, } \\
\text { PPP3CA, PRKCB1, } \\
\text { PTPN11, RUNX1, } \\
\text { SOS1, STAT5B }\end{array}$ & $1.04 \mathrm{e}-3$ & 2.9 & $10 / 62(0.16)$ \\
\hline Respuesta de Fase aguda & 19 & $\begin{array}{l}\text { AKT1, ALB, C3, C4A, } \\
\text { C4B, CEBPB, CFB, } \\
\text { ELK1, IKBKB, IL1F9, } \\
\text { MAPK11, MAPK1, } \\
\text { NR3C1, PIK3R1, } \\
\text { PTPN11, RBP7, } \\
\text { SERPINF1, SOS1, } \\
\text { TNF }\end{array}$ & $1.5 \mathrm{e}-3$ & 2.85 & $19 / 178(0.11)$ \\
\hline IL-4 & 10 & $\begin{array}{l}\text { AKT1, HLA-DMA, } \\
\text { HLA-DMB, HLA- } \\
\text { DOB, IRF4, NFATC1, } \\
\text { NFATC3, NR3C1, } \\
\text { PIK3R1, SOS1 } \\
\end{array}$ & $2.2 \mathrm{e}-3$ & 2.65 & $10 / 70(0.14)$ \\
\hline VDR/RXR & 11 & $\begin{array}{l}\text { CAMP, CEBPB, } \\
\text { DEFB4 (includes EG: } \\
\text { 1673), HOXA10, } \\
\text { IGFBP1, PDGFA, } \\
\text { PRKCB1, PRKCH, } \\
\text { PSMC5, RUNX2, } \\
\text { WT1 }\end{array}$ & $2.5 \mathrm{e}-3$ & 2.6 & $11 / 80(0.138)$ \\
\hline Presentación de Antígeno & 7 & $\begin{array}{l}\text { CALR, HLA-B, HLA- } \\
\text { DMA, HLA-DMB, } \\
\text { HLA-DOB, PSMB8, } \\
\text { TAP2 }\end{array}$ & $2.6 \mathrm{e}-3$ & 2.58 & $7 / 39(0.18)$ \\
\hline
\end{tabular}

A continuación se muestra de forma gráfica el resultado de este análisis. En el eje de ordenadas de la figura 32 se ofrecen los valores de la ratio observada/esperada para cascada de transmisión de señales, así como el valor logarítmico negativo del estadístico de contraste. En amarillo se pueden ver los valores concretos del estadístico de contraste, en este caso la p del test de Fisher, para cada caso. Al igual que en casos anteriores, el estadístico de contraste se representa como -Log (valor de p), los valores más altos serán los más significativos. La línea roja denota el 
punto de corte a partir del cual los valores son estadísticamente significativos (valor de $\mathrm{p}<0,05$ ).

Como se puede ver en la figura 32, las principales vías de transmisión de señales que aparecen presentan una clara relación con diferentes rutas relacionadas con el sistema inmune.

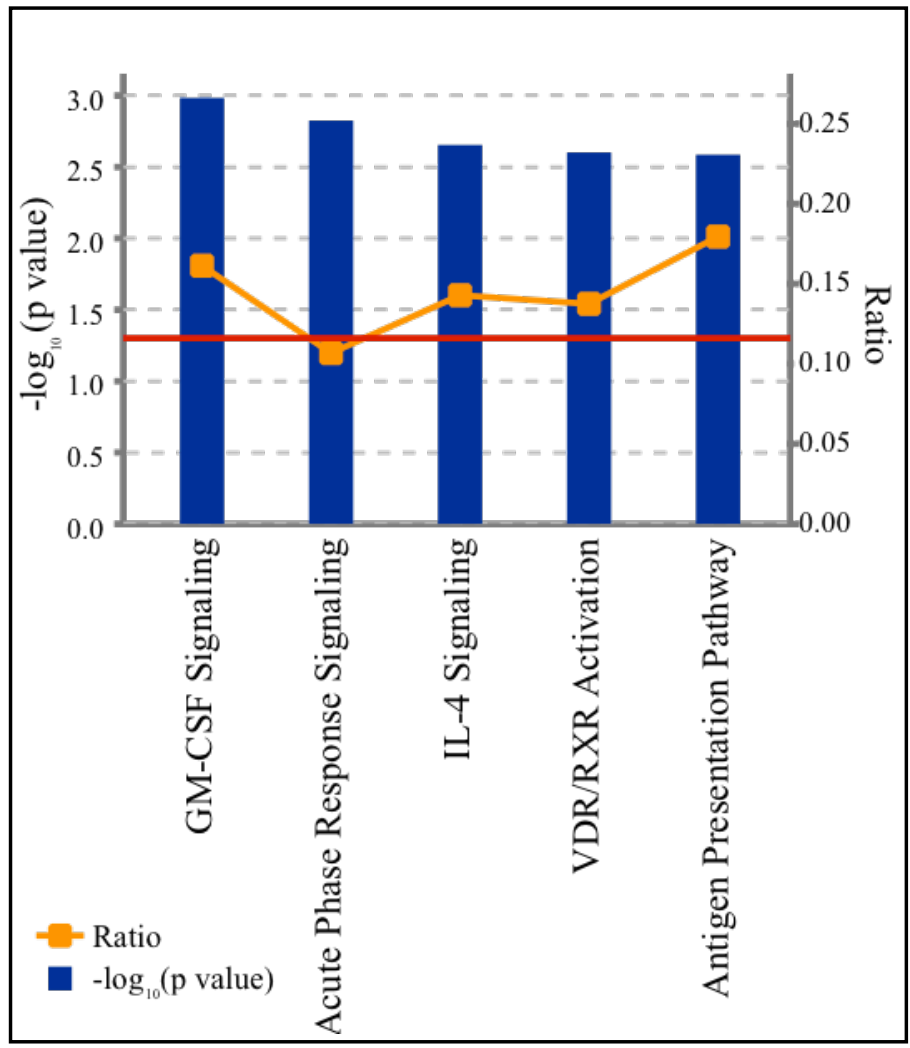

Figura 32. Imagen del análisis realizado usando IPA. En el eje de abscisas se representan los valores de - Log ( $p$ valor) y la ratio observados/esperados. En el eje de ordenadas se encuentran las cascadas de transmisión de señales más relevantes en este estudio. Como se puede ver en la figura, las principales redes están asociadas a respuestas del sistema inmune. 
5.4.1 Validación de los datos mediante MassArray

Como se ha comentado anteriormente, una de las ventajas de utilizar la espectrometría de masas en los estudios epigenéticos es que ofrece la posibilidad de cuantificar de manera precisa y rápida la mayoría de los dinucleótidos CpG en un amplicón dado, de una longitud que puede variar entre 200 y 400 pares de bases.

Para la validación técnica de las micromatrices se diseñaron oligos para amplificar regiones de corte HpaII de fragmentos de al menos 600 pares de bases que no tuvieran ningún otro punto de corte HpaII en al menos 2000 pares de bases.

\subsubsection{Validación técnica}

La validación técnica se realizó en las muestras seleccionadas para hacer las matrices. Se eligieron, de los datos obtenidos por HELP assay, tres regiones hipermetiladas, tres regiones hipometiladas y otras tres semimetiladas que mantuvieran el mismo estado entre ambos grupos.

Como se puede observar en la siguiente imagen (Figura 33) la correlación (R) entre los resultados obtenidos mediante HELP y los resultados obtenidos por MassArray es del 90\%. En el eje de abscisas se representan los valores de la ratio 
(HpaII/MspI), mientras que en el eje de ordenadas se representan los porcentajes de metilación obtenidos mediante MassArray.

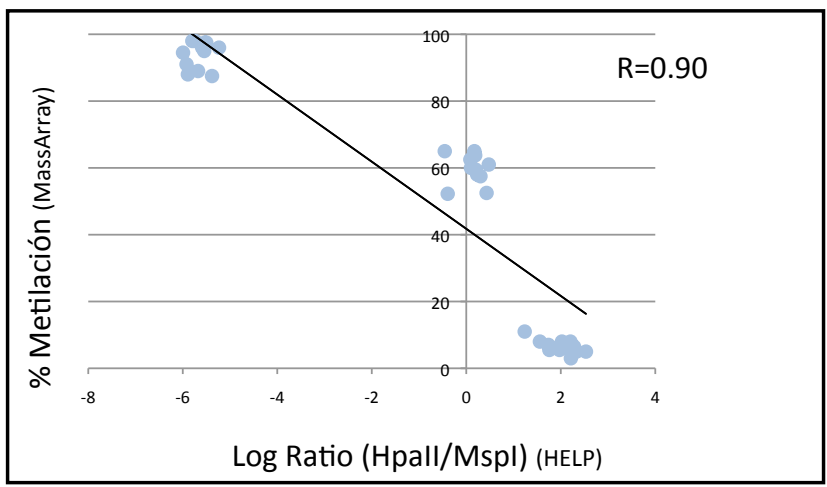

Figura 33. Validación técnica. En el eje de ordenadas se representa el porcentaje de metilación obtenido mediante MassArray y en el eje de abscisas el Log Ratio (HpaII/MspI) obtenido mediante HELP. La correlación de las dos técnicas es del 90\%.

\subsubsection{Validación biológica: CYP26A1}

Para la validación biológica se escogieron genes y regiones promotoras de los mismos que presentaran un patrón consistente de metilación diferencial entre alérgicos y controles. De entre ellos, CYP26A1, localizado en el brazo largo del cromosoma 10 (coordenadas cromosómicas según la alineación cromosómica HG18: chr10:94,833,232-94,837,641) fue el que presentaba mayores diferencias a lo largo tanto del promotor como del propio gen, como se puede ver en la figura 34, a continuación.

Se diseñaron oligos para amplificar 5 regiones diferentes a lo largo del promotor y del gen. El análisis se llevó a cabo en un total de 40 muestras, 20 pacientes y 20 controles, siempre por duplicado. En algunos casos, en los que los dinucleótidos 
CpG estaban muy próximos, se obtuvieron valores conjuntos de dos o tres dinucleótidos.

Como se puede ver en la figura 34, se observa una hipermetilación del promotor en el caso de pacientes alérgicos (en azul) frente a los controles (rojo), que se correlaciona con lo que observamos en HELP. En la tabla 14, se muestra la media del porcentaje de metilación para cada grupo, junto con la desviación estándar de la media (SEM) y un estadístico de contraste, en este caso el de la t de Student.

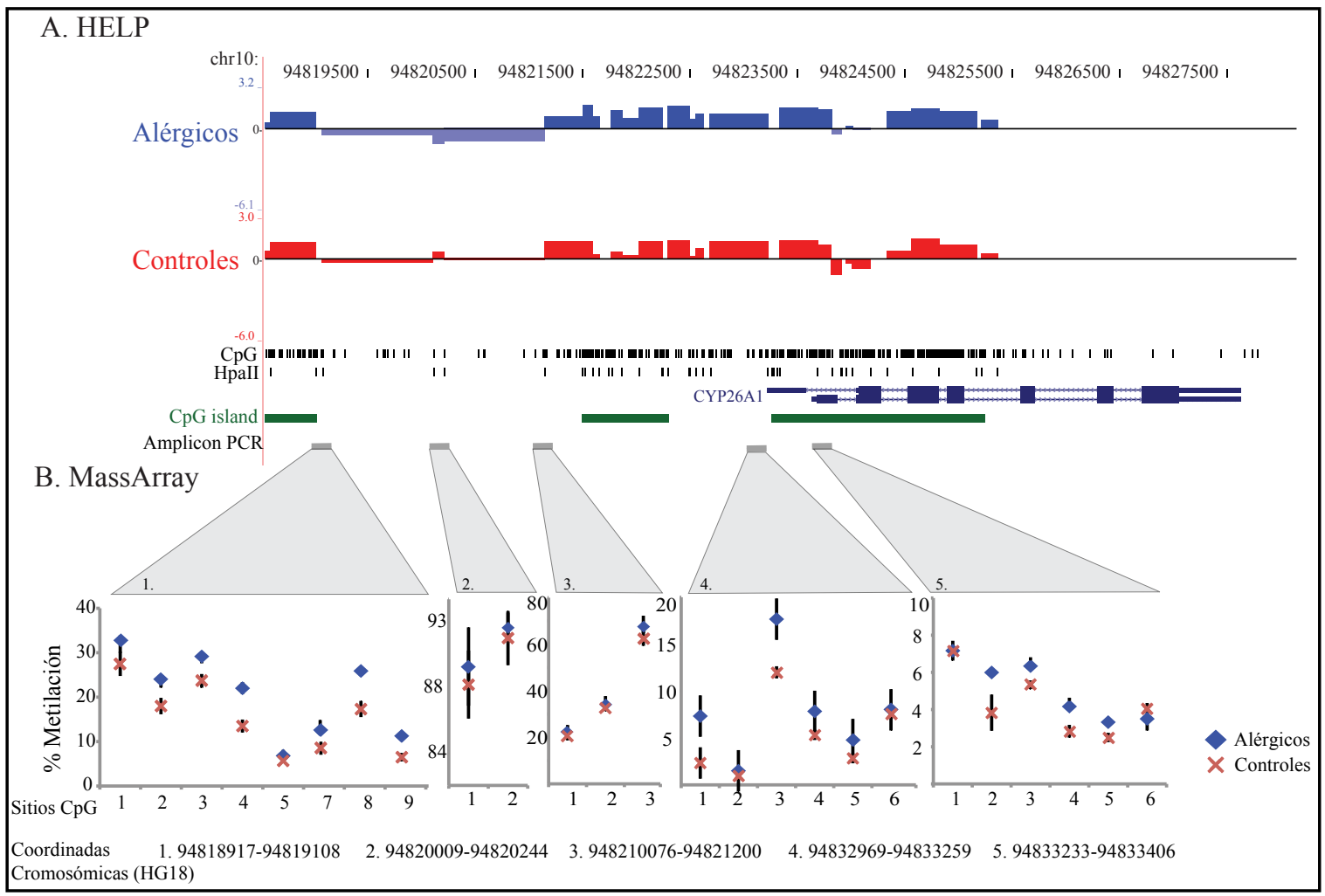

Figura 34. Validación biológica del gen $C Y P 26 A 1$. En la figura se muestran los datos a nivel cromosómico obtenidos mediante HELP assay, junto con los valores obtenidos mediante MassArray. Se representa, para cada grupo, la media del porcentaje de metilación junto con la desviación estándar de la media. 
En la parte superior de la figura 34 se puede ver una imagen de aproximadamente $5 \mathrm{~Kb}$ del brazo largo del cromosoma 10, donde se representan los resultados del HELP para el gen CYP26A1. Como se puede apreciar en la figura, el promotor de este gen está ligeramente hipermetilado en los pacientes alérgicos (representados en azul), cuando se comparan con los controles (en rojo). En la mitad inferior se pueden ver las zonas para las que se diseñaron oligos para la validación con MassArray. Los resultados obtenidos mediante esta técnica también están representados en la figura 34. En el eje de ordenadas se encuentra el porcentaje de metilación; en el de abscisas se representan los diferentes dinucleótidos. De la misma forma que antes, en azul se representan los controles y en rojo los alérgicos. 
Tabla 14. Porcentaje de metilación para cada grupo (alérgicos y controles), desviación estándar de la media y valor de $\mathrm{p}$ usando la t de Student. En negrita se representan los valores considerados como significativos (valor de $p<0,05)$

\begin{tabular}{|c|c|c|c|c|c|c|}
\hline & & & & & \\
\hline & & \multicolumn{2}{|c|}{ Alérgicos } & \multicolumn{2}{|c|}{ Controles } & \multirow[b]{2}{*}{ valor de $p$} \\
\hline & & \% Metilación & SEM & \% Metilación & SEM & \\
\hline \multirow{9}{*}{ Amplicon 1} & CpG 1 & 32.67 & 0.64 & 27.50 & 2.26 & 0.47 \\
\hline & CpG 2 & 24.00 & 0.62 & 18.00 & 0.90 & 0.001 \\
\hline & CpG 3.4 & 29.17 & 0.85 & 23.67 & 1.18 & 0.01 \\
\hline & CpG 5 & 22.17 & 1.28 & 13.50 & 1.08 & 0.04 \\
\hline & CpG 6 & 6.67 & 0.51 & 5.67 & 0.45 & 0.08 \\
\hline & CpG 7 & N/A & $\mathrm{N} / \mathrm{A}$ & N/A & $\mathrm{N} / \mathrm{A}$ & \\
\hline & CpG 8 & 12.50 & 0.71 & 7.17 & 0.55 & 0.001 \\
\hline & CpG 9 & 25.83 & 1.10 & 17.33 & 0.57 & 0.00002 \\
\hline & CpG 10 & 11.17 & 0.62 & 6.50 & 3.60 & 0.35 \\
\hline \multirow{2}{*}{ Amplicon 2} & CpG 1 & 89.67 & 0.80 & 88.50 & 0.69 & 0.75 \\
\hline & CpG 2 & 92.17 & 0.31 & 91.50 & 0.55 & 0.95 \\
\hline \multirow{4}{*}{ Amplicon 3} & CpG 1 & N/A & N/A & N/A & N/A & \\
\hline & CpG 2 & 22.00 & 1.32 & 18.31 & 0.50 & 0.80 \\
\hline & CpG 3 & 34.50 & 0.91 & 34.45 & 0.95 & 0.20 \\
\hline & CpG 4 & 68.50 & 0.75 & 66.18 & 0.66 & 0.89 \\
\hline \multirow{8}{*}{ Amplicon 4} & CpG 1 & N/A & $\mathrm{N} / \mathrm{A}$ & N/A & $\mathrm{N} / \mathrm{A}$ & \\
\hline & CpG 2 & N/A & $\mathrm{N} / \mathrm{A}$ & N/A & N/A & \\
\hline & CpG 3 & 7.33 & 1.04 & 2.33 & 0.53 & 0.35 \\
\hline & CpG 4 & 1.50 & 0.20 & 1.17 & 0.06 & 0.85 \\
\hline & CpG 5.6 & 17.67 & 0.43 & 12.00 & 0.20 & 0.25 \\
\hline & Cp 7.8 & 7.83 & 0.38 & 5.33 & 0.17 & 0.004 \\
\hline & CpG 9 & 4.83 & 0.32 & 2.83 & 0.17 & 0.58 \\
\hline & CpG 10.11 & 8.00 & 0.27 & 7.67 & 0.12 & 0.67 \\
\hline \multirow{6}{*}{ Amplicon 5} & CpG 1 & 7.17 & 0.26 & 7.17 & 0.17 & 1.00 \\
\hline & CpG 2 & 6.00 & 0.18 & 3.83 & 0.31 & 0.058 \\
\hline & CpG 3.4 & 6.33 & 0.17 & 5.33 & 0.07 & 0.09 \\
\hline & CpG 5.6 & 4.17 & 0.06 & 2.83 & 0.11 & 0.003 \\
\hline & CpG 7.8 & 3.33 & 0.07 & 2.50 & 0.08 & 0.02 \\
\hline & CpG 9.10.11 & 3.50 & 0.20 & 4.17 & 0.06 & 0.28 \\
\hline
\end{tabular}


Con el fin de profundizar en los resultados anteriormente descritos, se comprobaron los niveles de expresión del gen CYP26A1 en controles y pacientes.

Para el análisis se empleó un método de cuantificación relativa y normalización con un gen de referencia, en este caso GAPDH. Este método, descrito de forma detallada en el capítulo de Material y Métodos, se conoce como el método de Livak.

Este experimento reveló un descenso de la expresión de CYP26A1 a más de la mitad en los individuos alérgicos en comparación con individuos sanos, normalizado frente a la expresión de GAPDH. Este resultado concuerda con el estado de hipermetilación en el promotor de pacientes alérgicos, descrito anteriormente (Ver Figura 35).

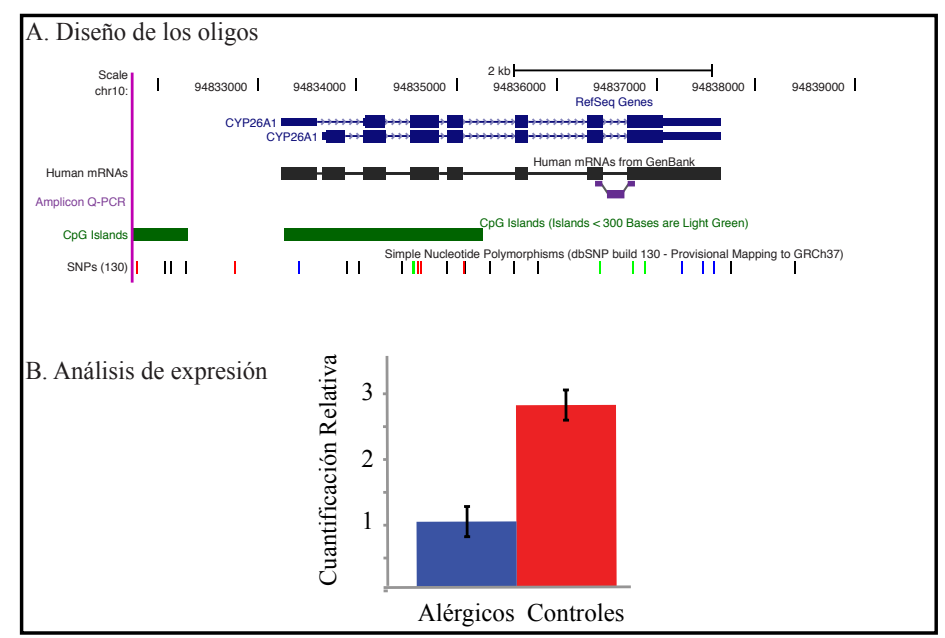

Figura 35. A. Imagen de la región cromosómica en la que se encuentra CYP26A1. En morado se representan los exones en los que se diseñaron los oligos. B. Resultado del análisis de expresión. En el eje de ordenadas se representa la diferencia relativa de expresión entre alérgicos y controles, que se encuentran en el eje de abscisas. Los valores están normalizados con GAPDH. Como se puede ver, los alérgicos presentan un descenso de la expresión de CYP26A1 
6Discusión 
El rápido avance científico en el campo de la tecnología aplicada a la Epigenética está permitiendo conocer con mayor detalle las características del epigenoma en situación fisiológica. El siguiente paso, por tanto, se centra en conocer qué alteraciones en el epigenoma se asocian con estados patológicos. Diversos estudios en distintos tipos de cáncer ya han puesto de manifiesto que las alteraciones en el epigenoma están presentes en estas enfermedades, no sólo en estados de hipermetilación en islas CpG (y por tanto reprimiendo la expresión) en regiones promotoras de genes supresores de tumores, sino también en estados de hipometilación en determinados loci que podrían contener oncogenes $(92,204)$. Además del cáncer, otras enfermedades complejas de las que se piensa podrían ser el resultado de una intrincada red de factores genéticos y ambientales, son actualmente objeto de estudios epigenéticos en un intento de entender mejor su origen y desarrollo $(205,206)$. Entre las enfermedades complejas influencias por desregulaciones epigenéticas podrían estar el asma, o la atopia (207) y han sido por ello objeto de este trabajo doctoral.

El asma alérgica y otras enfermedades alérgicas relacionadas, se presentan como los trastornos crónicos más frecuentes durante la infancia en numerosos países desarrollados, en los que el número de afectados puede llegar al 25\% del total de la población (174). Este hecho, además de suponer un enorme problema social con una fuerte carga económica, reduce de forma considerable la calidad de vida de los individuos afectados y la de sus familiares. Numerosos estudios han demostrado una tendencia al aumento de estas enfermedades durante los últimos treinta o cuarenta años, fundamentalmente en los países desarrollados, pero también en los países en vías de desarrollo. El hecho de que este aumento en la prevalencia se haya dado en un periodo de tiempo tan limitado hace poco probable que se deba 
únicamente a causas genéticas, y ha llevado a numerosos investigadores, entre los que se encuentra nuestro grupo, a plantearse la posibilidad de que influencias externas, entre los que se encontrarían diversos factores ambientales, puedan ejercer cierto efecto en la predisposición a padecer estas enfermedades (Pascual 2010, en prensa).

Así, además de la hipótesis de la higiene (132), que hace referencia únicamente a la posible relación entre diferentes factores ambientales y la predisposición a padecer asma, nuevas hipótesis han surgido encaminadas a entender este tipo de interacciones. La hipótesis de Baker (140) por ejemplo, publicada en 1992, postula que los diferentes órganos del individuo durante el periodo de gestación sufren una programación in utero, y que ésta será determinante en futuras adaptaciones fisiológicas y metabólicas durante la vida adulta. Esta hipótesis se extiende a otras enfermedades, además de la alérgica, postulando que determinadas agresiones ambientales o nutricionales durante las primeras fases del desarrollo pueden resultar en una mayor propensión a desarrollar enfermedades durante la vida adulta. De esta forma, diferentes estudios epidemiológicos y experimentales han puesto de manifiesto una relación entre la exposición a diversos factores ambientales durante la vida uterina y el posterior desarrollo de enfermedades. Entre estos factores influyentes durante la vida intrauterina se encontrarían diversos alérgenos, antibióticos y el humo de tabaco, que predispondrían al individuo a enfermedades como alergia (208), diabetes (205), enfermedades neurodegenerativas (209) y cardiovasculares (210).

Esta serie de observaciones ha dado lugar a una nueva versión de la hipótesis, conocida como Orígenes Fetales de Enfermedades en Adultos, en la que se 
propone que son las diferentes exposiciones durante la vida prenatal o muy temprana las que realmente alteran la programación celular, ya que tendrían lugar en un período de alta plasticidad genética durante el desarrollo (211).

La aceptación y el estudio de estas hipótesis han supuesto un aumento de los indicios existentes sobre una posible relación entre medio ambiente y Genética, en la que la Epigenética aparece como un posible vínculo que podría relacionarlos. La plasticidad que presentan los mecanismos epigenéticos los hacen muy atractivos para entender cómo diferentes exposiciones ambientales pueden modificar el epigenoma, y por tanto alterar los patrones de expresión celular, lo que acaba en una repercusión directa en la fisiopatología del individuo afectado. Concretamente, en este trabajo doctoral nos propusimos analizar los patrones epigenéticos de una población homogénea de pacientes con alergia a los ácaros que, además, presentaba síntomas de asma moderada o grave.

Se ha demostrado previamente que diferentes tipos celulares de un mismo organismo pueden presentar patrones epigenéticos bien diferenciados $(73,126)$. Aparte de disponer de datos de que linfocitos $\mathrm{CD}^{+}{ }^{+}$Th1 y Th2 presentan diferencias en sus patrones epigenéticos $(151,152)$, las poblaciones de linfocitos Th1 y Th2 se encuentran en un delicado equilibrio, en el que el aumento de las primeras supondría el descenso de las otras, y viceversa (212). Ya que para este trabajo necesitábamos una línea celular que fuera homogénea entre alérgicos y controles, que además fuera relativamente abundante en sangre periférica, decidimos centrar el estudio en linfocitos B CD19+. El marcador de superficie CD19 se expresa de manera universal y exclusiva en células B (213). Utilizamos este antígeno celular para realizar un aislamiento positivo de la población de células B 
circulantes en sangre periférica mediante un procedimiento inmunomagnético. Este tipo celular juega un importante papel durante las reacciones alérgicas, ya que no sólo secretan IgE específica de antígeno (células plasmáticas), sino que además presentan memoria inmunológica (células B de memoria), capaces de reconocer un antígeno previamente presentado, pueden actuar como células presentadoras de antígeno y además regenerar y reponer la población celular encargada de la producción de anticuerpos (214).

En nuestro esfuerzo por caracterizar, como sugieren las hipótesis de las que hablábamos anteriormente, la intrincada asociación entre alergia y epigenética, elegimos este grupo de pacientes con dos finalidades: (i) explorar la existencia de patrones epigenéticos específicos en un modelo de alergia respiratoria crónica, para lo que la alergia a ácaros es una de las formas más frecuentes; y (ii) evitar posibles variaciones estacionales, que podrían, hipotéticamente, afectar a los patrones epigenéticos, como en el caso de la alergia a los pólenes, presentes sólo en determinadas épocas del año.

Para el estudio de los patrones de metilación global utilizamos el HELP assay. La técnica, que ya ha sido descrita de forma detallada en este trabajo, nos permitió tener una visión tanto general como más local de las diferencias en los patrones de metilación.

El HELP assay ha demostrado ofrecer un balance óptimo entre resolución, cobertura genómica, rendimiento, calidad de los datos y coste. A diferencia de los métodos de afinidad, que presentan de forma característica un sesgo hacia fragmentos densos en $\mathrm{CpG}$, los métodos que se fundamentan en el uso de enzimas 
de restricción sólo se basan en la presencia de las secuencias de reconocimiento, ofreciendo un balance adecuado entre especificidad y sensibilidad. En este trabajo aprovechamos todas las ventajas de este enfoque, optimizando los ensayos de HELP assay para nuestras muestras biológicas de complicada obtención y de limitado material de partida (muestras de DNA nunca superiores a $3 \mu \mathrm{g}$, que se utilizaron tanto para HELP assay, como para las validaciones posteriores).

Los datos obtenidos del análisis de micromatrices realizado en este trabajo se encuentran depositados y estarán disponibles de forma pública en la base de datos GEO (http://www.ncbi.nlm.nih.gov/geo/).

Tras realizar un exhaustivo proceso de control de calidad y normalización de los datos obtenidos mediante HELP assay obtenidos tanto de los pacientes alérgicos como de los controles seleccionados, procedimos a su análisis bioinformático. Como parte del proceso de análisis de los datos publicado por Dr. Thompson en 2008 (195), se realizó un análisis global no supervisado, conocido como Dendograma. El resultado de este análisis (figura 27) mostró que, incluso dentro de la misma línea celular, existen ciertas diferencias entre pacientes y controles que hacen que en un análisis de pares y posterior agrupación por similitud, ambos grupos se disocien en dos conjuntos. El primero, muy claro y compacto formado por los controles, y el segundo, más disgregado, formado por los pacientes alérgicos. El hecho de que este último grupo no forme un conjunto tan compacto como el de los controles puede apuntar hacia la existencia de una mayor heterogeneidad epigenómica entre los pacientes alérgicos, sugiriendo que la alergia a ácaros puede ser el resultado de diferentes combinaciones de alteraciones epigenéticas. 
Se realizaron otros análisis a nivel global de forma supervisada, entre los que se encuentran theatmap, volcano plot o el p-values plot (figuras 29, 30 y 31), como diferentes formas para demostrar que, efectivamente, existen diferencias epigenéticas entre los linfocitos B de individuos sanos y pacientes asmáticos con asma y alergia a ácaros. En el heatmap (figura 29) se puede ver un patrón diferencial en la metilación entre los dos grupos, que se representa como una variación de colores que van desde el rojo (representando valores considerados como hipermetilados) al blanco (para los hipometilados).

En el volcano plot (figura 30) se representan las diferencias del logaritmo de la ratio (HpaII/MspI) entre alérgicos y controles frente al valor negativo del logaritmo del valor de p. Como se puede ver, la altitud (eje y) de los puntos muestra que efectivamente existen diferencias significativas entre pacientes y controles y que estas diferencias se encuentran en fragmentos hipermetilados en pacientes e hipometilados en controles y viceversa.

Para tener una idea general de la frecuencia con la que aparecen diferencias significativas entre ambos grupos, se hizo un p-values plot (figura 31). Como se puede ver en la figura, se representan la frecuencia, el número de veces que se observa un valor, frente al valor de p. Este gráfico viene a demostrar, de nuevo, la existencia de diferencias significativas entre alérgicos y controles en los datos obtenidos mediante HELP assay.

Posteriormente nos planteamos la identificación de los elementos específicos (genes y regiones promotoras) que presentaban las mayores diferencias entre controles y pacientes. Utilizando la notación genómica de Marzo de 2006 
(NCBI36/hg 18), se generó un listado que contenía todos los genes de RefSeq, incluyendo las regiones promotoras, definidas como \pm 1000 pares de bases desde el inicio de transcripción y se compararon con los datos generados mediante HELP assay, de los cuales poseíamos información cromosómica posicional. Este cruce de referencias y de estados de metilación nos permitió identificar un subgrupo de 100 loci que presentaban una diferencia absoluta en los valores de ratio logarítmicas (como medida del estado de metilación) mayor de dos unidades entre ambos grupos (alérgicos y controles). Para interrogar la relevancia funcional y las cascadas de transmisión de señales a las que pertenecían cada uno de estos genes y regiones promotoras, se utilizaron diferentes aproximaciones computacionales mediante el uso de la herramienta Ingenuity® Pathway Analysis, disponible a través del Servicio de Epigenómica del Albert Einstein College of Medicine. Esta herramienta ya ha demostrado ser muy poderosa en el análisis de resultados y generación de hipótesis en otros estudios $(206,215,216)$.

De esta forma, comprobamos que la mayoría de los locos están relacionados con cascadas de transmisión de señales características de la respuesta inmune (tabla 13 y figura 32). Usamos el análisis denominado Canonical Pathways, en el que se compararon valores esperados frente a observados para cada cascada de transmisión de señales. A esta ratio se le añade además un estadístico de contraste, con el fin de comprobar que la asociación no sea al azar. Entre las cascadas de transmisión que aparecieron como más significativas se encontraba la ruta en la que interviene el factor estimulador de colonias de granulocitos y macrófagos (GM-CSF, de sus siglas en inglés Granulocyte-Macrophage ColonyStimulating Factor). Esta pleiotrópica citocina desempeña un importante papel en la regulación de la hematopoyesis, así como en respuestas inmunes e inflamatorias 
(217). En líneas generales, durante los procesos inflamatorios la expresión de GMCSF aumenta. El aumento de esta citocina requiere la estimulación por parte de la IL-1, el TNF o el lipopolisacárido (LPS) (218). En modelos múridos con inflamación pulmonar crónica se ha observado que la neutralización de este factor con un anticuerpo específico mejora de forma significativa los síntomas del mismo $(219,220)$, y disminuye la hiperrespuesta de las vías respiratorias (156). Además, se sabe que la expresión constitutiva de GM-CSF induce eosinofilia, monocitosis, fibrosis, sensibilización antigénica y proliferación de macrófagos alveolares (217), característicos de la inflamación asmática.

En segundo lugar encontramos una metilación diferencial en la ruta de transmisión de señales de la Interleucina 4, característica de respuestas de tipo Th2 y típicamente asociada con alergia y asma (221). Esta citocina es secretada principalmente por células T inmaduras $\mathrm{CD}^{+}{ }^{+}$(222), células Th2 (223), linfocitos citolíticos espontáneos (natural killer) (224) y basófilos (225) en respuesta a determinados estímulos, entre los que se encuentra el antigénico (222). Las células Th2 regulan el cambio de isotipo de las células B hacia IgE gracias a la acción de la IL-4 (entre otros factores), lo que desencadenará una respuesta inflamatoria debido a la activación de basófilos y mastocitos, que secretarán citocinas, quimiocinas, histamina, heparina, serotonina y proteasas (226).

La vía de transmisión de señales celulares implicada en la presentación antigénica aparece en tercera posición. La presentación antigénica en el sistema inmune conlleva el procesamiento del antígeno, la asociación de éste con el Complejo Principal de Histocompatibilidad (MHC, de sus siglas en inglés Major Histocompatibility Complex) y la presentación antigénica por las células 
presentadoras de antígeno a través del MHC a los linfocitos T. Este proceso es crucial para la correcta activación de los linfocitos T.

La activación de los linfocitos B comienza tras la unión del antígeno con el Receptor de Células B (BCR). Tras esta estimulación, las células B pueden procesar y presentar el antígeno, en el contexto del MHC de clase II, a los linfocitos T y estimulando la proliferación y diferenciación de linfocitos B (227).

Otra de las vías de transmisión de señales que han aparecido en el presente trabajo es la relacionadas con la Respuesta a la vitamina D y los Receptores $\mathbf{X}$ del Acido Retinoico. La vitamina D3 es una hormona con importantes funciones en la regulación y el metabolismo del calcio y el fósforo en el intestino delgado, el riñón y tejido óseo. Al menos 60 tipos celulares distintos expresan receptores de Vitamina D (VDR) en el ser humano y hasta el momento se sabe de más de 200 genes que directa o indirectamente responden a la vitamina D (228), entre los que se encuentran responsables de la proliferación diferenciación celular, apoptosis y angiogénesis.

Diferentes variantes de los receptores de la vitamina D pueden suponer un factor de riesgo para sufrir asma (229). Además, se especula con la idea de que la vitamina D pueda tener cierta capacidad de modulación en el sistema inmune, y por tanto, ejercer un papel importante en la predisposición a padecer asma, dependiendo del momento de la exposición a esta vitamina (230-232).

La vitamina A es una hormona no esteroidea que desempeña un importante papel en los procesos de desarrollo, diferenciación y homeostasis. Los efectos 
pleiotrópicos de esta vitamina están mediados por los receptores de ácido retinoico (RAR) y los receptores $\mathrm{X}$ del ácido retinoico (RXR). El papel que desempeña esta vitamina en la predisposición y desarrollo de las enfermedades alérgicas será discutido más adelante en esta sección.

Nuestros estudios de metilación de DNA muestran por primera vez diferencias significativas a nivel global en los patrones epigenéticos en las células B de pacientes alérgicos e individuos sanos. Esta disgregación epigenética se asocia especialmente con genes involucrados en la respuesta inmune e inflamatoria y podría sugerir la existencia de una huella epigenética como causa y/o consecuencia del desarrollo de la alergia a ácaros. Además, nuestros resultados nos permiten especular con la posible utilidad de los análisis de metilación en el pronóstico y diagnóstico de la alergia a los ácaros, como ya se ha hecho en otros estudios $(233,234)$.

Cuando investigamos posibles diferencias en los patrones de metilación de DNA a nivel local obtenidos mediante HELP assay, encontramos que el promotor del gen CYP26A1, localizado en el brazo largo del cromosoma 10, presenta un patrón de metilación significativamente diferente entre pacientes alérgicos y controles. Como ya se ha explicado anteriormente, la metilación de citosinas en regiones promotoras se asocia convencionalmente con silenciamiento génico. Por lo tanto, el hecho de que el promotor del gen CYP26A1 presente unos patrones de metilación marcadamente diferentes entre pacientes e individuos sanos lo podría convertir en un buen gen candidato como biomarcador, no sólo en términos epigenéticos sino también de expresión génica. 
Si la primera técnica utilizada para investigar los patrones globales epigenéticos se basó en la digestión con enzimas de restricción, la validación local del promotor del gen CYP26A1 como biomarcador epigenético se realizó mediante tratamiento del DNA con bisulfito sódico, posterior amplificación de las regiones de interés mediante PCR y análisis mediante espectrometría de masas, conocido como MassArray. Con el fin de comprobar el posible hallazgo de un nuevo gen candidato asociado con las enfermedades alérgicas, se diseñaron oligos para amplificar diferentes regiones a lo largo del promotor del gen y verificar el estado de metilación a lo largo del mismo. Para realizar este tipo de experimentos y validar la región promotora del gen CYP26A1 como biomarcador, se amplió la población de estudio a un total de 40 individuos, de los cuales, como se ha especificado en el apartado de Material y Métodos, la mitad eran individuos control (figura 34). En consonancia con los resultados globales obtenidos usando el HELP assay, los datos del MassArray demostraron que el promotor del gen CYP26A1 se encuentra hipermetilado en las muestras de pacientes con asma atópica por ácaros, con unos niveles que en algunos casos suponen una moderada diferencia próxima al 10\% respecto a los controles.

Considerando que los procesos de hipermetilación en regiones promotoras se asocian convencionalmente con represión de la expresión génica, el siguiente planteamiento de este estudio fue el análisis de los niveles de expresión del gen en pacientes y controles. Para ello utilizamos un sistema de PCR cuantitativa en tiempo real y comprobamos que la hipermetilación observada tanto por HELP como por MassArray en la zona promotora de CYP26A1 se correlacionaba, en efecto, con un descenso significativo de la expresión de este gen en los linfocitos B CD19+ de los pacientes alérgicos a los ácaros (figura 35). 
Las diferencias en la metilación detectadas mediante la técnica del MassArray no alcanzan los niveles de desregulación que se han descrito en el cáncer. Sin embargo, un estudio realizado con individuos cuyas madres sufrieron la hambruna holandesa de 1944 ha puesto de manifiesto diferencias en la metilación del promotor de IGF2 (insuline-like growth factor II) del 5\%, que resultaron significativas cuando se compararon con los valores de metilación de los respectivos hermanos, nacidos cuando la hambruna ya había pasado (235). El hecho de que la literatura científica empiece a mostrar estudios en los que las diferencias moderadas en metilación sean significativas, quizá sea muestra de que repercusiones mínimas en el estado de metilación pueden tener importantes efectos fisiopatlóficos.

\subsection{La vitamina A en el Sistema Inmune}

La ingestión de vitamina A y el impacto que ésta ejerce en la biología humana ha sido objeto de estudio durante varias décadas. La ausencia de vitamina A en la dieta priva al organismo de sus derivados metabólicamente activos conocidos, como el retinol y el ácido retinoico (AR) (un alcohol y un ácido respectivamente). La ausencia de AR en humanos durante el desarrollo conlleva graves defectos en el sistema inmune, el desarrollo embrionario, la visión o el funcionamiento del cerebro $(236,237)$. El AR es por tanto, una molécula crítica que participa en numerosas rutas de transmisión de señales intracelulares, entre las que se encuentran algunas asociadas con la reproducción y el desarrollo embrionario, la competencia inmunológica o la regulación de la apoptosis (238). 
Diversos estudios apuntan que la vitamina A es un importante regulador del balance Th1/Th2; en este sentido, se ha demostrado que las dietas bajas en vitamina A presentan un sesgo en las respuestas de tipo Th1 (239-242), mientras que las dietas con exceso de esta vitamina podrían favorecer respuestas de tipo Th2 $(243,244)$, de las cuales se sabe regula directa o indirectamente la expresión de IFN- $\gamma$, IL-2, IL-4, IL-10 o IL-12 $(243,245,246)$.

En este sentido, numerosos estudios han demostrado que los animales que reciben dietas bajas en vitamina A presentan deficiencias en la producción de determinados anticuerpos. En términos generales la vitamina A es necesaria para la producción de anticuerpos en las respuestas frente a antígenos dependientes de células T, como el toxoide tetánico y antígenos celulares $(247,248)$ o antígenos T independientes de tipo 2 como los polisacáridos del neumococo (249). Sin embargo, los antígenos $\mathrm{T}$ independientes de tipo 1, como los lipopolisacáridos (LPS) pueden desencadenar intensas respuestas inmunes aún en animales deficientes en vitamina $A(250,251)$.

Estudios epidemiológicos realizados en países en vías de desarrollo ponen de manifiesto que la vitamina A es un importante factor en la regulación del correcto funcionamiento del sistema inmune. Así, poblaciones infantiles con graves deficiencias en la ingestión de vitamina A presentan un elevado número de casos de sarampión, cuya morbilidad y mortalidad es, además, más elevada debido a la aparición de complicaciones graves asociadas, entre las que se encuentran la neumonía o la diarrea (252).

En este sentido, diversos estudios clínicos demuestran que el aporte de Vitamina A en casos complicados de sarampión podrían ayudar a reducir la morbilidad y 
mortalidad asociada a la misma hasta en un $80 \%$ de los casos (253-255). Por otra parte, ya en 1987 se puso de manifiesto que una ingestión insuficiente de vitamina A se asocia con una incapacidad de controlar enfermedades derivadas de infecciones provocadas por bacterias, virus o protozoos (247) en modelos animales múridos. Si podemos asociar, por tanto, una dieta deficiente en vitamina A con una incapacidad de desarrollar respuestas de tipo Th1, las dietas que presentan un exceso en vitamina $\mathrm{A}$ han sido asociadas típicamente con una respuesta inmune propensa a desviaciones del tipo Th2 (256).

Así, se puede esperar que una dieta relativamente rica en vitamina A durante los primeros años de la infancia, frecuente en países industrializados, podría contribuir a desarrollar cierta tendencia hacia respuestas Th2 y, por tanto, influir hacia una mayor predisposición a sufrir alergia, entre otros. A pesar de que hay pocos estudios realizados en este sentido, en humanos se han llevado a cabo dos estudios, uno en Estados Unidos (257) y otro en Suiza (258) en el que se pone de manifiesto una relación entre la toma de suplementos multivitamínicos (en los que se incluye vitamina A) durante los seis primeros meses de vida y posterior desarrollo de enfermedades asmáticas y alérgicas.

En este sentido, modelos animales han demostrado que dietas bajas en vitamina A frenan el desarrollo de respuestas Tipo Th2 tras la provocación con ovoalbúmina (OVA) en ratones previamente sensibilizados, mientras que dietas ricas en esta vitamina en los mismos animales fueron un agravante de los síntomas alérgicos (259), lo que conllevó un aumento de IgE en suero (260). 
Sin embargo, en un estudio de seguimiento realizado en 200 recién nacidos durante 20 años se pudo comprobar que las concentraciones séricas bajas de retinol en suero a los dos meses de edad se correlacionaba con el desarrollo de enfermedades alérgicas durante la vida adulta (261). En otro estudio transversal realizado en una población juvenil (de 6 a 18 años) en Arabia Saudí se demostró un descenso significativo de los niveles de ácido retinoico en el suero de pacientes asmáticos (262). En este sentido, estudios in vitro en los que se cultivaron células B estimuladas con IL-4 y CD40 en presencia de AR han descrito una inhibición de la síntesis de IgE mediante el silenciamiento de la transcripción de IL-6 y el descenso de proteolisis de sCD23 y sCD54 (263).

\subsubsection{Regulación de la expresión celular}

Los derivados metabólicos activos de la vitamina A son el ácido trans retinoico (AR), y el retinal (9-cis retinoico). Estos metabolitos son capaces de unirse a dos familias de receptores nucleares diferentes, conocidas como RAR y RXR (de sus siglas en inglés Retinoic Acid Receptor y Retinoic X Receptor). Cada familia tiene tres isotipos: $\alpha, \beta$ y $\gamma$. RAR y RXR se unen formando heterodímeros funcionales. Según el modelo actual de activación transcripcional, en ausencia de ligando los heterodímeros se unen al DNA reclutando otros co-represores con actividad desacetilasa de histonas, lo que conllevaría un estado de mayor condensación de la cromatina, resultando en un estado de silenciamiento génico (264).

En el caso opuesto, una vez que el ligando se une al heterodímero RAR/RXR, se producen cambios conformacionales en el mismo que favorecen la disociación de correpresores transcripcionales y el reclutamiento de otras proteínas con 
actividad acetilasa de histonas, que facilitarían un estado abierto de la cromatina y por tanto la transcripción génica (264).

La secuencia de unión para los heterodímeros RXR/RAR se encuentra altamente conservada entre diferentes especies y se conoce como RARE (de sus siglas en inglés, Retinoic Acid Response Element). Los RARE consisten en una repetición directa de un hexámero PuG(G/T)TCA, separados por 1, 2 ó 5 pares de bases (265).

Se han identificado más de 532 genes que podrían estar regulados por el ácido retinoico. En algunos casos el control es directo, en cuyo caso la regulación se lleva a cabo mediante el heterodímero RXR/RAR, mientras que en otros casos el control es indirecto, llevándose a cabo por otros intermediarios (266).

En el promotor de CYP26A1 se han descrito dos elementos RARE. El primero de ellos (R1) se encuentra en la región proximal del promotor y se sabe que es el responsable de regular niveles bajos de transcripción del citocromo. El segundo elemento (R2), se encuentra aproximadamente a 2,5 kb del inicio de transcripción, y actuaría de forma sinérgica con R1 para aumentar los niveles de transcripción de la proteína (267).

\subsubsection{Metabolismo del ácido retinoico: CYP26A1}

Como ya se ha comentando antes, el ácido retinoico es el derivado biológicamente activo de la vitamina A. Dadas sus numerosas e importantes funciones en la fisiología celular, no resulta extraño que la concentración celular de AR sea rigurosamente controlada, estando la disponibilidad del mismo regulada por 
mecanismos de biosíntesis y de degradación. Se sintetiza gracias a la actividad coordinada de una familia de retinaldehído deshidrogeasas (RALDH: RALDH1, $R A L D H 2, R A L D H 3, R A L D H 4)$, que oxidan de forma irreversible el retinaldehído a AR (268). De todos ellos, se sabe que la $R A L D H 2$ es la que presenta unos patrones de expresión más ampliamente distribuidos (269).

El catabolismo del ácido retinoico se lleva a cabo por una familia enzimática de citocromos que se conocen como CYP, pertenecientes a la familia de citocromos P450, y que fueron descubiertos como un grupo de enzimas responsables del catabolismo del AR (270). Se han descrito tres miembros activos de esta familia, CYP26A1, CYP26B1 y CYP26C1, capaces de oxidar el AR a metabolitos más polares, entre los que se encuentran la 4-oxo-AR, la 4-OH-AR, y la 18-OH-AR, biológicamente inactivos in vivo (267). A pesar de que todas están involucradas, en mayor o menor grado, en el catabolismo del AR, los estudios de transfección celular sugieren que es la CYP26A1 la principal responsable de este proceso (271)

Los ratones nuligénicos (knock-out) para los genes RALDH2 o CYP26A1 mueren durante los primeros días del desarrollo embrionario, poniendo así de manifiesto la enorme importancia de una correcta distribución del AR durante las primeras etapas del crecimiento $(272,273)$. 


\subsection{Consideraciones Finales}

A pesar de los múltiples esfuerzos que se han llevado a cabo para intentar entender la fisiopatología de las enfermedades alérgicas, parece que hacen falta muchos más estudios básicos, clínicos y epidemiológicos con el fin de detectar posibles factores de riesgo susceptibles de ser controlados mediante planes de intervención.

Es poco probable que un sólo estudio identifique todos los factores que en potencia pueden intervenir en el desarrollo de las enfermedades alérgicas. Interacciones entre diferentes factores ambientales, posibles efectos que las distintas influencias ambientales tengan en el epigenoma y el componente genético individual desempeñan un complicado papel en la predisposición de cada individuo a padecer una determinada enfermedad. El desarrollo (y estudio) de enfermedades complejas, como el asma y la alergia, se presenta así como una intrincada red en la que participan tanto factores genéticos, como ambientales y epigenéticos y en la que diferentes combinaciones de las mismas podrían dar lugar a fenotipos similares de la enfermedad.

En este trabajo presentamos, por primera vez, un estudio sistemático del epigenoma de linfocitos $\mathrm{B}$ de pacientes alérgicos, en este caso con alergia a ácaros y asma moderada o grave. Tras un estudio metódico de los valores de metilación del epigenoma a nivel global, hemos expuesto de forma concisa que existen diferencias en los patrones de metilación entre controles y pacientes. 
Pese a que, como demuestra la literatura, los niveles de ingesta de vitamina A son un factor determinante en la predisposición de enfermedades alérgicas, las características de la dieta de la población no ha sido un factor epidemiológico recogido de forma sistemática en la historia clínica de los individuos estudiados en este trabajo, por lo que es difícil evaluar el efecto epidemiológico que tiene en la población, si bien dadas las características poblacionales en un entorno de bienestar y desarrollo es esperable que los niveles vitamínicos sean los adecuados o superiores.

En este estudio describimos un nuevo gen candidato, CYP26A1, que podría estar relacionado con la patología de la atopia, estudiando tanto los niveles de metilación como de expresión del mismo. En el caso de los pacientes alérgicos, el promotor aparece hipermetilado respecto a los controles, lo que se corresponde con un descenso de la expresión del gen en este grupo. Si los niveles de expresión de CYP26A1 se encuentran alterados en otros tipos celulares o en otros tipos de enfermedades alérgicas nos es desconocido. Tampoco sabemos si esta marca epigenética es exclusiva de los linfocitos B maduros o por el contrario está presente ya en los progenitores de la línea linfoblastoide, pudiendo tener un origen durante el desarrollo y ser por tanto común a otras líneas linfoides.

No es posible determinar en este estudio si el aumento en la expresión de este citocromo es causa de la enfermedad o consecuencia de la misma. En cualquier caso, y a pesar del tamaño muestral en este trabajo, hemos identificado una nueva posible diana terapéutica, que abre la posibilidad a futuros estudios que ayuden a entender la etiología de la enfermedad y el desarrollo de nuevos fármacos para tratarla. 
Se requieren más estudios de este tipo, en los que se examine un mayor número de líneas celulares con diferentes fenotipos de la enfermedad en poblaciones más amplias para poder entender mejor lo que ocurre en enfermedades complejas como el asma y la atopia. 
7 Conclusiones 

1. Las diferencias observadas en el patrón de metilación global de los linfocitos B de los pacientes con asma alérgica podrían estar relacionadas con el desarrollo de esta enfermedad.

2. Se han identificado diversos loci con patrón de metilación diferencial en distintas vías de transmisión de señales que se relacionan con diferentes aspectos de la respuesta inmunológica. Entre ellas, las vías de transmisión de señales relacionadas con el factor estimulador de colonias de monocitos y granulocitos, con la respuesta inflamatoria de fase aguda, con la interleucina 4, con la presentación antigénica, con los receptores de vitamina D y los receptores X de ácido retinoico.

3. Se describe por primera vez que el promotor de CYP26A1 presenta en linfocitos B unos niveles de metilación elevados en los pacientes alérgicos. Este aumento podría estar directamente relacionado con el descenso observado en la expresión de dicho gen en estos pacientes.

4. Considerando las modificaciones detectadas, tanto en los patrones de metilación como en sus niveles de expresión, el gen CYP26A1 podría estar implicado en el desarrollo del asma alérgica a través de mecanismos epigenéticos. 




\section{Indice de figuras}

Figura 1 Representación esquemática de las células implicadas y mediadores implicados en la respuesta alérgica.

Figura 2. Cambio de isotipo de IgM a IgE en la respuesta alérgica. Modificado de Gould et al. (13) 32

Figura 3 Imagen a microscopio electrónico de D. pteronyssinus. Las medidas del ácaro oscilan entre los 420 micrómetros de largo y 250 o 320 micrómetros de ancho.

Figura 4 Variación de la prevalencia de asma entre diferentes países. Los números indican el porcentaje de individuos de cada país que sufren de asma (54).

Figura 5. Representación del modelo actualmente aceptado para el comienzo de inactivación del cromosoma X (94).

Figura 6. Niveles de metilación (negro) y no metilación (gris) de loci que sufren marcado genómico y de aquellos que no (rojo, materno; azul paterno) durante el desarrollo embrionario. En el eje de ordenadas se representa el porcentaje de metilación y en el de abscisas el tiempo (103). $\quad 54$

Figura 7. Aproximadamente el $45 \%$ del genoma humano se puede clasificar dentro de la categoría de elementos móviles del genoma. La mayoría de estos elementos corresponden a LTR (108). $\quad 55$

Figura 8. Representación de los tres métodos disponibles para el estudio de metilación de DNA 60

Figura 9 La reacción química con el bisulfto convierte las citosinas no metiladas en uracilos mediante una reacción de sulfonación, desaminación hidrolítica y por último desulfonación en medio alcalino.

Figura 10. Representación esquemática del locus de las citocinas Th2. Las flechas indican la direccionalidad de la transcripción para cada gen. Los asteriscos negros representan sitios de hipersensibilidad a DNasaI (HS). Con un asterisco rojo se representa RHS7 y con un asterisco negro de mayor tamaño se representa la zona de HS IV. Los rectángulos en verde simbolizan zonas no codificantes altamente conservadas (CNS1 y CNS2). El locus que controla la región (LCR) aparece subrayado. Modificado de van Panhyus (151)

Figura 11. Interacción entre la predisposición genética individual y las exposiciones ambientales mediante alteraciones en el epigenoma y posterior desarrollo de enfermedades atópicas. (Pascual y cols 2010, en prensa)

Figura 12. Representación esquemática de la separación de la fracción linfoide a partir de sangre total 89

Figura 13. Curvas estándar generadas a partir de diluciones seriadas para los oligos diseñados para A. CYP26A1 y B. GAPDH. El valor del coeficiente de determinación se muestra en cada caso, sobre la gráfica

Figura 14. Principio del HELP assay. Este método se basa en la comparación de las representaciones genómicas tras la digestión de HpaII o su esquizómera, MspI. En la primera versión de HELP, los fragmentos representados tenían una longitud de 200 a 2000 pb. En la nueva versión este rango se incrementó hasta incluir fragmentos de $50 \mathrm{pb}$. Mientras que loci como el representado en A debería estar representado tanto en HpaII como en MspI, considerando que HpaII no corta en los casos B y C, sólo tendremos la representación en MspI. La metilación parcial en D generaría una ratio HpaII/MspI menor que en el caso A. En la caso de que haya una mutación, como en el caso E, no se obtendrá señal alguna ni con HpaII ni con MspI.(126)

105

Figura 15. Visión general del proceso de marcaje, hibridación, adquisición y análisis de los datos. Las librerías generadas por la digestión de MspI y HpaII para una misma muestra se marcan con distintos fluoróforos para después co-hibridarlos en un mismo array.

Figura 16. Resultados de un chip de DNA de Agilent. En la imagen se muestra el marcador de tamaño molecular y el resultado de HELP assay de una misma muestra tratada con MspI o HpaII 
Figura 17. Representación esquemática del análisis de metilación mediante espectrometría de masas MALDI-TOF. Los oligos utilizados contienen una secuencia promotora de T7. En este ejemplo se representan en amarillo una secuencia metilada y otra no metilada, en rojo. Las variaciones en la secuencia tendrán una repercusión en el peso molecular del fragmento, que serán detectadas mediante espectrometría de masas (124).

Figura 18. Porcentaje de células B CD20+ obtenidas mediante citometría de flujo.

Figura 19. Imagen de dos geles de agarosa al $1 \%$ teñidos con bromuro de etidio. A 1 . Marcador de tamaño molecular 2. Banda de DNA genómico de una de las muestras. B 1. Marcador de tamaño molecular 2. Producto de la digestión de DNA con HpaII (que se mantiene en forma de alto tamaño molecular) 3. Producto de la digestión con MspI (que presenta una digestión completa del DNA)

Figura 20. Imagen de dos geles de agarosa al $1 \%$ teñidos con bromuro de etidio A1. Marcador de tamaño molecular. 2. Producto de la digestión con HpaII 3. Producto de la digestión con MspI. B 1. Marcador de tamaño molecular. Tras la generación de las librerías y amplificación de las mismas (LM-PCR), se puede ver el producto de 2.HpaII y 3.MspI

129

Figura 21. Control de calidad realizado en tres muestras diferentes. Se representan los tres canales, MspI, HpaII y Ratio (LogHpaII/MspI) para cada muestra. La muestra 1 es el resultado de un control de calidad adecuado debido a una buena hibridación. Los artefactos espaciales debidos a una mala hibriadación se pueden observar en las muestras 2 y $3 \mathrm{El}$ color verde revela señales menos intensas que la media de intensidades de la matriz, mientras que el color rojo denota intensidades superiores a la media.

Figura 22. Gráfico de densidades tras la normalización de cuantiles. En el eje de ordenadas se representa la densidad frente a la ratio HpaII/MspI para controles y alérgicos.

Figura 23.Gráficos de densidades de las intensidades obtenidas en MspI, HpaII y la ratio (HpaII/MspI) respectivamente. En el eje de ordenadas se representan los valores de intensidad de los fragmentos. En el eje de abscisas, la densidad.

132

Figura 24. Representación gráfica de intensidad frente a longitud en fragmentos digeridos con HpaII. En el eje de ordenadas se representa el logaritmo de la intensidad de HpaII frente a la longitud de los fragmentos, en el eje de abscisas. En este caso la línea roja simboliza el punto de corte de fragmentos que están metilados. Como se puede observar en la figura, HpaII presenta una densidad mayor de fragmentos de pequeño tamaño y una gran intensidad. Este patrón es característico del canal de HpaII.

Figura 25. Representación gráfica de intensidad frente a longitud en fragmentos digeridos con MspI. En el eje de ordenadas se representa el logaritmo de la intensidad de MspI frente a la longitud de los fragmentos (en pares de bases), en el eje de abscisas. En este caso la línea roja simboliza el punto de corte de fragmentos que serán eliminados del estudio Como se puede observar en la figura, MspI presenta una densidad mayor de fragmentos alrededor de las 500 pares de bases y una gran intensidad. Este patrón es característico del canal de MspI.

Figura 26. Representación gráfica de intensidad frente al logaritmo del ratio (HpaII/MspI). En el eje de ordenadas se representa el logaritmo de la intensidad del ratio frente a la longitud de los fragmentos (en pares de bases), en el eje de abscisas. En este caso la línea roja simboliza el punto de corte entre fragmentos que son considerados como hipometilados (por encima de la línea) e hipermetilados (por debajo de la línea).

134

Figura 27. Unión de dos análisis, formando lo que se conoce como dendograma, un análisis no supervisado y un análisis de pares usando la correlación de Pearson. Las tres muestras de controles y las tres de pacientes alérgicos se compararon usando la mínima varianza de Ward y las distancias entre matrices fueron calculadas como la distancia euclidiana entre las ratios de los mismos. La línea roja punteada representa el punto de corte de la distancia euclidiana usada para separar los diferentes grupos de muestras. Los valores de correlación de Pearson se muestran en 
la parte superior, mientras que los puntos azules sirven como representación visual de las diferencias entre muestras.

Figura 28. Visualización de los datos de HELP en el Genome Browser. En esta imagen se muestran los datos obtenidos por HELP de una pequeña parte del brazo largo del cromosoma 10. Por definición, los fragmentos hipometilados son los que presentan una ratio (HpaII/MspI) positiva, como se puede ver en la figura de la izquierda. Esto se transforma, en el Genome Browser, en que los fragmentos que están por encima de la línea son los hipometilados, mientras que los fragmentos hipermetilados, con una ratio negativa, se encuentran por debajo de esta línea.

Figura 29. Análisis supervisado jerárquico de dos dimensiones representado por un Heatmap. Se representan 1000 loci escogidos al azar de entre aquellos que presentaban una diferencia en el Log Ratio mayor de 1,4 unidades entre alérgicos y controles y un valor de p menor de 0,05. Las muestras se representan en las columnas, los diferentes loci en filas

Figura 30. Volcano-Plot. En el eje de ordenadas se representa el valor negativo del logaritmo del estadístico de contraste valor de valor de $\mathrm{p}$, mientras que en el eje de abscisas se representa la diferencia de intensidades (ratio HpaII/MspI) entre alérgicos y controles.

Figura 31. P-values plot. En el eje de abscisas se representan los valores del estadístico de contraste (valor de p) frente a la frecuencia con la que éste aparece.

Figura 32. Imagen del análisis realizado usando IPA. En el eje de abscisas se representan los valores de Log ( $p$ valor) y la ratio observados/esperados. En el eje de ordenadas se encuentran las cascadas de transmisión de señales más relevantes en este estudio. Como se puede ver en la figura, las principales redes están asociadas a respuestas del sistema inmune.

Figura 33. Validación técnica. En el eje de ordenadas se representa el porcentaje de metilación obtenido mediante MassArray y en el eje de abscisas el Log Ratio (HpaII/MspI) obtenido mediante HELP. La correlación de las dos técnicas es del $90 \%$.

Figura 34. Validación biológica del gen CYP26A1. En la figura se muestran los datos a nivel cromosómico obtenidos mediante HELP assay, junto con los valores obtenidos mediante MassArray. Se representa, para cada grupo, la media del porcentaje de metilación junto con la desviación estándar de la media.

Figura 35. A. Imagen de la región cromosómica en la que se encuentra CYP26A1. En morado se representan los exones en los que se diseñaron los oligos. B. Resultado del análisis de expresión. En el eje de ordenadas se representa la diferencia relativa de expresión entre alérgicos y controles, que se encuentran en el eje de abscisas. Los valores están normalizados con GAPDH. Como se puede ver, los alérgicos presentan un descenso de la expresión de CYP26A1 


\section{Indice de tablas}

Tabla 1. Clasificación de las reacciones de hipersensibilidad propuesta por Coombs y Gell ......................................23

Tabla 2. Marcadores de superficie durante las diferentes etapas del desarrollo de linfocitos B..............................29

Tabla 3. Reactivos, cantidad y concentración final de los mismos para un volumen total de 3L del tampón de tratamiento empleado en el acondicionamiento de las bolsas de diálisis.

Tabla 4. Reactivos, cantidad y concentración inicial de los mismos para un volumen total de $10 \mathrm{~mL}$ de solución amortiguadora de lisis.

Tabla 5. Programa utilizado para la realización de la PCR cuantitativa......................................................................100

Tabla 6. Oligos utilizados en los experimentos de PCR cuantitativa..........................................................................101

Tabla 7. Reactivos y respectivos volúmenes añadidos a cada muestra para llevar a cabo la reacción de ligación.

Tabla 8. Secuencia de los adaptadores utilizados en la preparación de la librería de DNA para HELP assay...109

Tabla 9. Reactivos y respectivos volúmenes para preparar la solución maestra de la PCR.

Tabla 10. A. Reactivos y volúmenes utilizados en las reacciones de cadena de la polimerasa (PCR). B. Programa utilizado para las PCR. Tan: Temperatura específica de primer.

Tabla 11. Oligos utilizados en los experimentos de PCR para la validación técnica. Se añadieron las secuencias "aggaagagag" en la posición 5' de los oligos forward y también en la posición 5' se añadió la secuencia "cagtaatacgactcactatagggagaaggct" en el caso de los oligos "reverse".Tan se expresa en ${ }^{\circ} \mathrm{C}$.

Tabla 12. Oligos utilizados en los experimentos de PCR para la validación del gen CYP26A1. Ya que estos oligos fueron utilizados para el MassArray, se añadieron las secuencias "aggaagagag" en la posición 5' de los oligos forward y también en la posición 5' se añadió "cagtaatacgactcactatagggagaaggct" en el caso de los oligos reverse. Tan se expresa en ${ }^{\circ} \mathrm{C}$.

Tabla 13. Resultados del análisis llevado a cabo mediante IPA. Se muestran los valores de las cascadas de transmisión de señales intracelulares que resultaron significativas. La ratio se calculó teniendo en cuenta el número de genes observados en los datos del estudio frente el total de genes involucrados en esa determinada ruta celular

Tabla 14. Porcentaje de metilación para cada grupo (alérgicos y controles), desviación estándar de la media y valor de $\mathrm{p}$ usando la $\mathrm{t}$ de Student. En negrita se representan los valores considerados como significativos (valor de $\mathrm{p}<0,05$ ) 


\section{Abreviaturas}

AID: Citidín desaminasa inducida por activación (Activation Induced cytidine Deaminase)

AINE: antiinflamatorios no esteroideos

APC: células presentadoras de antígeno

ATS: Asociación Torácica Amaricana (American Thoracic Society)

BCR: Receptor de células B (B Cell Receptor)

CCL2: Ligando de quimiocinas 2

ChIP: Inmunoprecipitación de cromatina

COBRA: Análisis combinado de bisulfito y enzimas de restricción (Combined Bisulphite Restriction Analysis)

COPD: EPOC , enfermedad pulmonar obstructiva crónica (chronic obstructive pulmonary disease)

CpG: dinucélotido citosina seguido de guanina

CXCL-8: Interleucina 8

cys-LTs: leucotrienos cisteinílicos

DMH: hibridación por diferencia de metilación. (Differential Methylation Hybridization)

DMR: Regiones de metilación diferencial (Differentially Methylated Regions)

DNMTs: DNA metiltransferasas (DNA methyl transferases)

EAACI: Academia Europea de Alergia e Inmulogía Clínica (European Academy of Allergy and Clinical Immunology)

Fc $\varepsilon$ RI: receptores de alta afinidad para IgE

GINA: Estrategia Global para el Asma (The Global Initiative for Asthma)

GM-CSF: Factor estimulador de crecimiento de granulocitos y monocitos (Granulocyte-macrophage colony-stimulating factor)

HAT: acetil transferasas de histonas (Histone acetyltransferases)

HDAC: histona desacetilasas (Histone deacetylases)

HELP assay: Enriqueciemiento de fragmentos HpaII mediante ligación y PCR (HpaII tiny fragment Enrichment by Ligation mediated PCR)

HMT: metiltransferasa de histonas (Histone methyltransferases)

HTF pequeños fragmentos generados por HpaII (HpaII Tiny Fragments)

ICR: Región de control de huella genómica (Imprinting Control Region) 
Ig: Inmunoglobulina

IgE: Inmunoglubulina E

IL: interleucina

INF- $\gamma$ : Interferón $\gamma$

kb :kilobases

kDa: KiloDalton

LINE: Elementos nucleares dispersos largos(Long Interspersed Nuclear Elements) ,

LM-PCR: PCR mediada por Ligación (Ligation Mediated PCR)

LMP: Progenitor Linfoide-Mieloide (Lymphoid Mieliod Progenitor)

LPS: lipopolisacárido

LT: leucotrienos

LTB-4 : leucotrieno B4

LTR: Repecticiones largas terminales (Long Terminal Repeats),

MAD: Desviación absoulta de la media (Median Absolute Deviation)

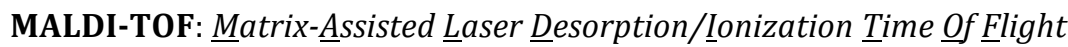

MBD: Dominios de unión a metilación (Methyl-Binding Domains)

MeCP2: methyl CpG-binding protein 2

MHCI: Complejo Mayor de Histocompatibilidad I

MHCII: Complejo Mayor de Histocompatibilidad II

miRNA: microRNAs

mRNA: RNA mensajero

MSDK: Methylation Sensitive Digital Karyotyping

MSP: PCR específica de metilación (Methylation-Specific PCR)

ncRNA: RNA no codificante (Non Coding RNA)

Nf-кB: Factor nuclear KappaB (Nuclear Factor-KappaB)

NK: Células citolíticas espontáneas(Natural Killer)

OVA: ovoalbúmina

PAH: Hidrocarbonos policíclicos aromáticos (Polycyclic Aromatic Hydrocarbons)

pb: pares de bases

PEG: polietilenglicol

PGD2: prostaglandina D2

rpm: revoluciones por minuto

SAM: S-adenosín-L metionina 
SEM: error estándar de la media (Standard error of the mean)

SINE: Elementos nucleares dispersos largos (Short Interspersed Nuclear Elements)

SiRNA: RNA pequeño de interferencia (Small interference RNA)

SSC: solución amortiguadora de cloruro sódico y citrato sódico

SSDNA: DNA de cadena sencilla (Single strand DNA)

STAT: Señal de transducción y activación de la transcripción (Signal Transducer and activator of transcription)

Tann: Temperatura de anillamiento

TE: Elementos móviles del genoma (Transposable Elements)

TGF $\boldsymbol{\beta}$ : Factor de crecimiento transformante beta (Transforming growth factor beta)

TIR: Repeticiones terminales invertidas (Terminal Inverted Repeats)

TNF $\alpha$ : Factor de Necrosis Tumoral $\alpha$ (Tumor Necrosis Factor alpha)

TSS : Sitio de comienzo de la transcripción (Transcription Start Site)

VEGFA: Factor de crecimento vasculo-endotelial A ( Vascular Endothelial $\underline{\text { Growth }} \underline{\text { Factor }} \underline{\mathrm{A}}$ )

Xce: X-chromosome-controlling element

Xic: $X$-chromosome -inactivation

Xist: X (inactive)-specific transcript 


\section{IReferencias \\ Bibliográficas}

1. Vercelli D. Discovering susceptibility genes for asthma and allergy. Nature reviews. 2008 Mar;8(3):169-82.

2. Galli SJ, Tsai M, Piliponsky AM. The development of allergic inflammation. Nature. 2008 Jul 24;454(7203):445-54.

3. Kay AB. Allergy and allergic diseases. First of two parts. The New England journal of medicine. 2001 Jan 4;344(1):30-7.

4. GINA. Global Strategy for Asthma Management and Prevention 2006.

5. Roy SR, McGinty EE, Hayes SC, Zhang L. Regional and racial disparities in asthma hospitalizations in Mississippi. J Allergy Clin Immunol. 2010 Mar;125(3):636-42.

6. Kiley J, Smith R, Noel P. Asthma phenotypes. Curr Opin Pulm Med. 2007 Jan;13(1):19-23.

7. Averbeck M, Gebhardt C, Emmrich F, Treudler R, Simon JC. Immunologic principles of allergic disease. J Dtsch Dermatol Ges. 2007 Nov;5(11):1015-28.

8. Spergel JM, Paller AS. Atopic dermatitis and the atopic march. The Journal of allergy and clinical immunology. 2003 Dec;112(6 Suppl):S118-27.

9. Rhodes HL, Thomas P, Sporik R, Holgate ST, Cogswell JJ. A birth cohort study of subjects at risk of atopy: twenty-two-year follow-up of wheeze and atopic status. American journal of respiratory and critical care medicine. 2002 Jan 15;165(2):176-80.

10. Gustafsson D, Sjoberg 0, Foucard T. Development of allergies and asthma in infants and young children with atopic dermatitis--a prospective follow-up to 7 years of age. Allergy. 2000 Mar;55(3):240-5.

11. Kulig M, Bergmann R, Klettke U, Wahn V, Tacke U, Wahn U. Natural course of sensitization to food and inhalant allergens during the first 6 years of life. The Journal of allergy and clinical immunology. 1999 Jun;103(6):1173-9.

12. von Piquet C. Allergy. Münch Med Wochenschr. 1906;53:1457-8.

13. Gould HJ, Sutton BJ. IgE in allergy and asthma today. Nature reviews. 2008 Mar;8(3):205-

17.

14. Wu CH, Lee MF. Molecular characteristics of cockroach allergens. Cell Mol Immunol. 2005 Jun;2(3):177-80.

15. Pichler WJ. Delayed drug hypersensitivity reactions. Ann Intern Med. 2003 Oct 21;139(8):683-93.

16. Posadas SJ, Pichler WJ. Delayed drug hypersensitivity reactions - new concepts. Clin Exp Allergy. 2007 Jul;37(7):989-99.

17. Hari Y, Urwyler A, Hurni M, Yawalkar N, Dahinden C, Wendland T, et al. Distinct serum cytokine levels in drug- and measles-induced exanthema. Int Arch Allergy Immunol. 1999 Nov;120(3):225-9. 
18. Nassif A, Bensussan A, Dorothee G, Mami-Chouaib F, Bachot N, Bagot M, et al. Drug specific cytotoxic T-cells in the skin lesions of a patient with toxic epidermal necrolysis. J Invest Dermatol. 2002 Apr;118(4):728-33.

19. Mosmann TR, Cherwinski H, Bond MW, Giedlin MA, Coffman RL. Two types of murine helper $\mathrm{T}$ cell clone. I. Definition according to profiles of lymphokine activities and secreted proteins. J Immunol. 1986 Apr 1;136(7):2348-57.

20. Bluestone JA, Abbas AK. Natural versus adaptive regulatory T cells. Nature reviews. 2003 Mar;3(3):253-7.

21. Sakaguchi S, Wing K, Miyara M. Regulatory T cells - a brief history and perspective. Eur J Immunol. 2007 Nov;37 Suppl 1:S116-23.

22. Fontenot JD, Gavin MA, Rudensky AY. Foxp3 programs the development and function of CD4+CD25+ regulatory T cells. Nature immunology. 2003 Apr;4(4):330-6.

23. Wan YY, Flavell RA. Regulatory T-cell functions are subverted and converted owing to attenuated Foxp3 expression. Nature. 2007 Feb 15;445(7129):766-70.

24. Ling EM, Smith T, Nguyen XD, Pridgeon C, Dallman M, Arbery J, et al. Relation of CD4+CD25+ regulatory T-cell suppression of allergen-driven T-cell activation to atopic status and expression of allergic disease. Lancet. $2004 \mathrm{Feb} 21 ; 363(9409): 608-15$.

25. Burrows PD, Cooper MD. B cell development and differentiation. Current opinion in immunology. 1997 Apr;9(2):239-44.

26. Gordon MY BM. The biological basis of clinical problems. Blackwell Scientific Publications. 1985.

27. Maizels N. Immunoglobulin gene diversification. Annu Rev Genet. 2005;39:23-46.

28. Nemazee D. Receptor editing in B cells. Advances in immunology. 2000;74:89-126.

29. Peled JU, Kuang FL, Iglesias-Ussel MD, Roa S, Kalis SL, Goodman MF, et al. The biochemistry of somatic hypermutation. Annual review of immunology. 2008;26:481-511.

30. Shen $\mathrm{CH}$, Stavnezer J. Activation of the mouse Ig germline epsilon promoter by IL-4 is dependent on AP-1 transcription factors. J Immunol. 2001 Jan 1;166(1):411-23.

31. Tedder TF, Isaacs CM. Isolation of cDNAs encoding the CD19 antigen of human and mouse B lymphocytes. A new member of the immunoglobulin superfamily. J Immunol. 1989 Jul 15;143(2):712-7.

32. Matsumoto AK, Martin DR, Carter RH, Klickstein LB, Ahearn JM, Fearon DT. Functional dissection of the CD21/CD19/TAPA-1/Leu-13 complex of B lymphocytes. The Journal of experimental medicine. 1993 Oct 1;178(4):1407-17.

33. Fearon DT, Carter RH. The CD19/CR2/TAPA-1 complex of B lymphocytes: linking natural to acquired immunity. Annual review of immunology. 1995;13:127-49.

34. Pate MB, Smith JK, Chi DS, Krishnaswamy G. Regulation and dysregulation of immunoglobulin E: a molecular and clinical perspective. Clin Mol Allergy. 2010;8:3.

35. Carter RH, Wang Y, Brooks S. Role of CD19 signal transduction in B cell biology. Immunol Res. 2002;26(1-3):45-54.

36. KleinJan A, Vinke JG, Severijnen LW, Fokkens WJ. Local production and detection of (specific) IgE in nasal B-cells and plasma cells of allergic rhinitis patients. Eur Respir J. 2000 Mar;15(3):491-7.

37. Holgate ST, Polosa R. Treatment strategies for allergy and asthma. Nature reviews. 2008 Mar;8(3):218-30.

38. Boyce JA. Mast cells and eicosanoid mediators: a system of reciprocal paracrine and autocrine regulation. Immunological reviews. 2007 Jun;217:168-85. 
39. Galli SJ, Kalesnikoff J, Grimbaldeston MA, Piliponsky AM, Williams CM, Tsai M. Mast cells as "tunable" effector and immunoregulatory cells: recent advances. Annual review of immunology. 2005;23:749-86.

40. Gilfillan AM, Tkaczyk C. Integrated signalling pathways for mast-cell activation. Nature reviews. 2006 Mar;6(3):218-30.

41. Sarin S, Undem B, Sanico A, Togias A. The role of the nervous system in rhinitis. The Journal of allergy and clinical immunology. 2006 Nov;118(5):999-1016.

42. Cevikbas F, Steinhoff A, Homey B, Steinhoff M. Neuroimmune interactions in allergic skin diseases. Current opinion in allergy and clinical immunology. 2007 Oct;7(5):365-73.

43. Lalloo UG, Barnes PJ, Chung KF. Pathophysiology and clinical presentations of cough. The Journal of allergy and clinical immunology. 1996 Nov;98(5 Pt 2):S91-6; discussion S6-7.

44. Rivera J, Gilfillan AM. Molecular regulation of mast cell activation. The Journal of allergy and clinical immunology. 2006 Jun;117(6):1214-25; quiz 26.

45. Kay AB, Ali FR, Heaney LG, Benyahia F, Soh CP, Renz H, et al. Airway expression of calcitonin gene-related peptide in T-cell peptide-induced late asthmatic reactions in atopics. Allergy. 2007 May;62(5):495-503.

46. Murdoch JR, Lloyd CM. Chronic inflammation and asthma. Mutat Res. 2009 Sep 19.

47. Holgate ST. Epithelium dysfunction in asthma. The Journal of allergy and clinical immunology. 2007 Dec;120(6):1233-44; quiz 45-6.

48. Gern JE, Busse WW. Relationship of viral infections to wheezing illnesses and asthma. Nature reviews. 2002 Feb;2(2):132-8.

49. Leung DY, Boguniewicz M, Howell MD, Nomura I, Hamid QA. New insights into atopic dermatitis. The Journal of clinical investigation. 2004 Mar;113(5):651-7.

50. Pawankar R, Nonaka M, Yamagishi S, Yagi T. Pathophysiologic mechanisms of chronic rhinosinusitis. Immunology and allergy clinics of North America. 2004 Feb;24(1):75-85.

51. Chapman AD. Numbers of Living Species in Australia and the World. Reports for the Department of the Environment and Heritage. 2007.

52. Walter DE, Proctor H.C. Mites: Ecology, Evolution and Behaviour. Sydney: University of New South Wales Press; 1999.

53. Fernandez-Caldas E, Puerta L, Caraballo L, Lockey RF. Mite allergens. Clinical allergy and immunology. 2008;21:161-82.

54. Devereux G. The increase in the prevalence of asthma and allergy: food for thought. Nature reviews. 2006 Nov;6(11):869-74.

55. Vercelli D. Genetics, epigenetics, and the environment: switching, buffering, releasing. The Journal of allergy and clinical immunology. 2004 Mar;113(3):381-6; quiz 7.

56. Peters SP, Ferguson G, Deniz Y, Reisner C. Uncontrolled asthma: a review of the prevalence, disease burden and options for treatment. Respiratory medicine. 2006 Jul;100(7):1139-51.

57. Martin JA, Kochanek KD, Strobino DM, Guyer B, MacDorman MF. Annual summary of vital statistics--2003. Pediatrics. 2005 Mar;115(3):619-34.

58. Preparing a healthcare workforce for the 21st century: the challenge of chronic conditions. Chronic Illn. 2005 Jun;1(2):99-100.

59. Ninan TK, Russell G. Respiratory symptoms and atopy in Aberdeen schoolchildren: evidence from two surveys 25 years apart. BMJ (Clinical research ed. 1992 Apr 4;304(6831):873-5.

60. Gaig P, Ferrer, M., Muñoz-Lejarazu, D., Lleonart, R., García-Abujeta, J.L., Caballero, T., Rodríguez, A., Echechipia, S., Martínez-Cocera, C., Domínguez, F. J., Gonzalo, M. A., Olona, M. Prevalencia de alergia en la población adulta española. Alergol Inmunol Clin. 2004(19):7. 
61. Neugut AI, Ghatak AT, Miller RL. Anaphylaxis in the United States: an investigation into its epidemiology. Arch Intern Med. 2001 Jan 8;161(1):15-21.

62. CDC. New Asthma Estimates: Tracking Prevalence, Health Care and Mortality. In: Prevention CfDCa, editor.2001.

63. Study AaAFa. The Costs of Asthma2000.

64. Waddington CH. Preliminary Notes on the Development of the Wings in Normal and Mutant Strains of Drosophila. Proceedings of the National Academy of Sciences of the United States of America. 1939 Jul;25(7):299-307.

65. Delcuve GP, Rastegar M, Davie JR. Epigenetic control. Journal of cellular physiology. 2009 May;219(2):243-50.

66. Klose RJ, Bird AP. Genomic DNA methylation: the mark and its mediators. Trends in biochemical sciences. 2006 Feb;31(2):89-97.

67. Mellor J. The dynamics of chromatin remodeling at promoters. Molecular cell. 2005 Jul 22;19(2):147-57.

68. Burgers WA, Fuks F, Kouzarides T. DNA methyltransferases get connected to chromatin. Trends Genet. 2002 Jun;18(6):275-7.

69. Wang Y, Fischle W, Cheung W, Jacobs S, Khorasanizadeh S, Allis CD. Beyond the double helix: writing and reading the histone code. Novartis Foundation symposium. 2004;259:3-17; discussion -21, 163-9.

70. Santos-Rosa H, Schneider R, Bannister AJ, Sherriff J, Bernstein BE, Emre NC, et al. Active genes are tri-methylated at K4 of histone H3. Nature. 2002 Sep 26;419(6905):407-11.

71. Bauer UM, Daujat S, Nielsen SJ, Nightingale K, Kouzarides T. Methylation at arginine 17 of histone H3 is linked to gene activation. EMBO reports. 2002 Jan;3(1):39-44.

72. Lachner M, O'Carroll D, Rea S, Mechtler K, Jenuwein T. Methylation of histone H3 lysine 9 creates a binding site for HP1 proteins. Nature. 2001 Mar 1;410(6824):116-20.

73. Lister R, Pelizzola M, Dowen RH, Hawkins RD, Hon G, Tonti-Filippini J, et al. Human DNA methylomes at base resolution show widespread epigenomic differences. Nature. 2009 Nov 19;462(7271):315-22.

74. Bird AP. CpG-rich islands and the function of DNA methylation. Nature. 1986 May 1521;321(6067):209-13.

75. Feltus FA, Lee EK, Costello JF, Plass C, Vertino PM. DNA motifs associated with aberrant CpG island methylation. Genomics. 2006 May;87(5):572-9.

76. Suzuki MM, Bird A. DNA methylation landscapes: provocative insights from epigenomics. Nature reviews. 2008 Jun;9(6):465-76.

77. Illingworth R, Kerr A, Desousa D, Jorgensen H, Ellis P, Stalker J, et al. A novel CpG island set identifies tissue-specific methylation at developmental gene loci. PLoS biology. 2008 Jan;6(1):e22.

78. Guil S, Esteller M. DNA methylomes, histone codes and miRNAs: tying it all together. The international journal of biochemistry \& cell biology. 2009 Jan;41(1):87-95.

79. Li E, Bestor TH, Jaenisch R. Targeted mutation of the DNA methyltransferase gene results in embryonic lethality. Cell. 1992 Jun 12;69(6):915-26.

80. Tost J. DNA methylation: an introduction to the biology and the disease-associated changes of a promising biomarker. Methods in molecular biology (Clifton, NJ. 2009;507:3-20.

81. Okano M, Bell DW, Haber DA, Li E. DNA methyltransferases Dnmt3a and Dnmt3b are essential for de novo methylation and mammalian development. Cell. 1999 Oct 29;99(3):247-57.

82. Yoder JA, Bestor TH. A candidate mammalian DNA methyltransferase related to pmt1p of fission yeast. Human molecular genetics. 1998 Feb;7(2):279-84. 
83. Tweedie S, Ng HH, Barlow AL, Turner BM, Hendrich B, Bird A. Vestiges of a DNA methylation system in Drosophila melanogaster? Nature genetics. 1999 Dec;23(4):389-90.

84. Hermann A, Schmitt S, Jeltsch A. The human Dnmt2 has residual DNA-(cytosine-C5) methyltransferase activity. The Journal of biological chemistry. 2003 Aug 22;278(34):31717-21.

85. Okano M, Xie S, Li E. Dnmt2 is not required for de novo and maintenance methylation of viral DNA in embryonic stem cells. Nucleic acids research. 1998 Jun 1;26(11):2536-40.

86. Jurkowski TP, Meusburger M, Phalke S, Helm M, Nellen W, Reuter G, et al. Human DNMT2 methylates tRNA(Asp) molecules using a DNA methyltransferase-like catalytic mechanism. RNA (New York, NY. 2008 Aug;14(8):1663-70.

87. Phalke S, Nickel O, Walluscheck D, Hortig F, Onorati MC, Reuter G. Retrotransposon silencing and telomere integrity in somatic cells of Drosophila depends on the cytosine-5 methyltransferase DNMT2. Nature genetics. 2009 Jun;41(6):696-702.

88. Filion GJ, Zhenilo S, Salozhin S, Yamada D, Prokhortchouk E, Defossez PA. A family of human zinc finger proteins that bind methylated DNA and repress transcription. Molecular and cellular biology. 2006 Jan;26(1):169-81.

89. Barreto G, Schafer A, Marhold J, Stach D, Swaminathan SK, Handa V, et al. Gadd45a promotes epigenetic gene activation by repair-mediated DNA demethylation. Nature. 2007 Feb 8;445(7128):671-5.

90. Bhattacharya SK, Ramchandani S, Cervoni N, Szyf M. A mammalian protein with specific demethylase activity for mCpG DNA. Nature. 1999 Feb 18;397(6720):579-83.

91. Morgan HD, Dean W, Coker HA, Reik W, Petersen-Mahrt SK. Activation-induced cytidine deaminase deaminates 5-methylcytosine in DNA and is expressed in pluripotent tissues: implications for epigenetic reprogramming. The Journal of biological chemistry. 2004 Dec 10;279(50):52353-60.

92. Esteller M. Epigenetics in cancer. The New England journal of medicine. 2008 Mar 13;358(11):1148-59.

93. Amir RE, Van den Veyver IB, Wan M, Tran CQ, Francke $U$, Zoghbi HY. Rett syndrome is caused by mutations in X-linked MECP2, encoding methyl-CpG-binding protein 2. Nature genetics. 1999 Oct;23(2):185-8.

94. Avner P, Heard E. X-chromosome inactivation: counting, choice and initiation. Nature reviews. 2001 Jan;2(1):59-67.

95. Lee JT, Davidow LS, Warshawsky D. Tsix, a gene antisense to Xist at the X-inactivation centre. Nature genetics. 1999 Apr;21(4):400-4.

96. Simmler MC, Cattanach BM, Rasberry C, Rougeulle C, Avner P. Mapping the murine Xce locus with (CA)n repeats. Mamm Genome. 1993 Sep;4(9):523-30.

97. Chow JC, Brown CJ. Forming facultative heterochromatin: silencing of an X chromosome in mammalian females. Cell Mol Life Sci. 2003 Dec;60(12):2586-603.

98. Barlow D, Bartolomei, M. Genomic imprinting in mammals. Epigenetics. 2007:357-75.

99. Edwards CA, Ferguson-Smith AC. Mechanisms regulating imprinted genes in clusters. Current opinion in cell biology. 2007 Jun;19(3):281-9.

100. Spahn L, Barlow DP. An ICE pattern crystallizes. Nature genetics. 2003 Sep;35(1):11-2.

101. Stoger R, Kubicka P, Liu CG, Kafri T, Razin A, Cedar H, et al. Maternal-specific methylation of the imprinted mouse Igf2r locus identifies the expressed locus as carrying the imprinting signal. Cell. 1993 Apr 9;73(1):61-71.

102. Feil R, Walter J, Allen ND, Reik W. Developmental control of allelic methylation in the imprinted mouse Igf2 and H19 genes. Development (Cambridge, England). 1994 Oct;120(10):2933-43. 
103. Reik W, Walter J. Genomic imprinting: parental influence on the genome. Nature reviews. 2001 Jan;2(1):21-32.

104. Kaneda M, Okano M, Hata K, Sado T, Tsujimoto N, Li E, et al. Essential role for de novo DNA methyltransferase Dnmt3a in paternal and maternal imprinting. Nature. 2004 Jun 24;429(6994):900-3.

105. Bourc'his D, Bestor TH. Meiotic catastrophe and retrotransposon reactivation in male germ cells lacking Dnmt3L. Nature. 2004 Sep 2;431(7004):96-9.

106. Bourc'his D, Xu GL, Lin CS, Bollman B, Bestor TH. Dnmt3L and the establishment of maternal genomic imprints. Science (New York, NY. 2001 Dec 21;294(5551):2536-9.

107. Lander ES, Linton LM, Birren B, Nusbaum C, Zody MC, Baldwin J, et al. Initial sequencing and analysis of the human genome. Nature. $2001 \mathrm{Feb} 15 ; 409(6822): 860-921$.

108. Cordaux R, Batzer MA. The impact of retrotransposons on human genome evolution. Nature reviews. 2009 Oct;10(10):691-703.

109. Kim JK, Samaranayake M, Pradhan S. Epigenetic mechanisms in mammals. Cell Mol Life Sci. 2009 Feb;66(4):596-612.

110. Deininger PL, Moran JV, Batzer MA, Kazazian HH, Jr. Mobile elements and mammalian genome evolution. Current opinion in genetics \& development. 2003 Dec;13(6):651-8.

111. Hasler J, Strub K. Alu elements as regulators of gene expression. Nucleic acids research. 2006;34(19):5491-7.

112. Kazazian HH, Jr. An estimated frequency of endogenous insertional mutations in humans. Nature genetics. 1999 Jun;22(2):130.

113. Rae PM, Steele RE. Absence of cytosine methylation at C-C-G-G and G-C-G-C sites in the rDNA coding regions and intervening sequences of Drosophila and the rDNA of other insects. Nucleic acids research. 1979 Jul 11;6(9):2987-95.

114. Walsh CP, Chaillet JR, Bestor TH. Transcription of IAP endogenous retroviruses is constrained by cytosine methylation. Nature genetics. 1998 Oct;20(2):116-7.

115. Ren B, Robert F, Wyrick JJ, Aparicio O, Jennings EG, Simon I, et al. Genome-wide location and function of DNA binding proteins. Science (New York, NY. 2000 Dec 22;290(5500):2306-9.

116. Liu CL, Schreiber SL, Bernstein BE. Development and validation of a T7 based linear amplification for genomic DNA. BMC genomics. 2003 May 9;4(1):19.

117. Mikkelsen TS, Ku M, Jaffe DB, Issac B, Lieberman E, Giannoukos G, et al. Genome-wide maps of chromatin state in pluripotent and lineage-committed cells. Nature. 2007 Aug 2;448(7153):553-60.

118. Barski A, Cuddapah S, Cui K, Roh TY, Schones DE, Wang Z, et al. High-resolution profiling of histone methylations in the human genome. Cell. 2007 May 18;129(4):823-37.

119. Robertson G, Hirst M, Bainbridge M, Bilenky M, Zhao Y, Zeng T, et al. Genome-wide profiles of STAT1 DNA association using chromatin immunoprecipitation and massively parallel sequencing. Nature methods. 2007 Aug;4(8):651-7.

120. Johnson DS, Mortazavi A, Myers RM, Wold B. Genome-wide mapping of in vivo proteinDNA interactions. Science (New York, NY. 2007 Jun 8;316(5830):1497-502.

121. Colella S, Shen L, Baggerly KA, Issa JP, Krahe R. Sensitive and quantitative universal Pyrosequencing methylation analysis of CpG sites. BioTechniques. 2003 Jul;35(1):146-50.

122. Herman JG, Graff JR, Myohanen S, Nelkin BD, Baylin SB. Methylation-specific PCR: a novel PCR assay for methylation status of CpG islands. Proceedings of the National Academy of Sciences of the United States of America. 1996 Sep 3;93(18):9821-6.

123. Xiong Z, Laird PW. COBRA: a sensitive and quantitative DNA methylation assay. Nucleic acids research. 1997 Jun 15;25(12):2532-4. 
124. Ehrich M, Nelson MR, Stanssens P, Zabeau M, Liloglou T, Xinarianos G, et al. Quantitative high-throughput analysis of DNA methylation patterns by base-specific cleavage and mass spectrometry. Proceedings of the National Academy of Sciences of the United States of America. 2005 Nov 1;102(44):15785-90.

125. Huang TH, Laux DE, Hamlin BC, Tran P, Tran H, Lubahn DB. Identification of DNA methylation markers for human breast carcinomas using the methylation-sensitive restriction fingerprinting technique. Cancer research. 1997 Mar 15;57(6):1030-4.

126. Khulan B, Thompson RF, Ye K, Fazzari MJ, Suzuki M, Stasiek E, et al. Comparative isoschizomer profiling of cytosine methylation: the HELP assay. Genome research. 2006 Aug;16(8):1046-55.

127. Weber M, Hellmann I, Stadler MB, Ramos L, Paabo S, Rebhan M, et al. Distribution, silencing potential and evolutionary impact of promoter DNA methylation in the human genome. Nature genetics. 2007 Apr;39(4):457-66.

128. Taylor KH, Kramer RS, Davis JW, Guo J, Duff DJ, Xu D, et al. Ultradeep bisulfite sequencing analysis of DNA methylation patterns in multiple gene promoters by 454 sequencing. Cancer research. 2007 Sep 15;67(18):8511-8.

129. Korshunova Y, Maloney RK, Lakey N, Citek RW, Bacher B, Budiman A, et al. Massively parallel bisulphite pyrosequencing reveals the molecular complexity of breast cancer-associated cytosine-methylation patterns obtained from tissue and serum DNA. Genome research. 2008 Jan;18(1):19-29.

130. Cokus SJ, Feng S, Zhang X, Chen Z, Merriman B, Haudenschild CD, et al. Shotgun bisulphite sequencing of the Arabidopsis genome reveals DNA methylation patterning. Nature. 2008 Mar 13;452(7184):215-9.

131. Bibikova M, Fan JB. GoldenGate assay for DNA methylation profiling. Methods in molecular biology (Clifton, NJ. 2009;507:149-63.

132. Strachan DP. Hay fever, hygiene, and household size. BMJ (Clinical research ed. 1989 Nov 18;299(6710):1259-60.

133. Busse WW. The relationship between viral infections and onset of allergic diseases and asthma. Clin Exp Allergy. 1989 Jan;19(1):1-9.

134. Romagnani S. Type $1 \mathrm{~T}$ helper and type $2 \mathrm{~T}$ helper cells: functions, regulation and role in protection and disease. International journal of clinical \& laboratory research. 1991;21(2):152-8.

135. Romagnani S. Coming back to a missing immune deviation as the main explanatory mechanism for the hygiene hypothesis. The Journal of allergy and clinical immunology. 2007 Jun;119(6):1511-3.

136. Fallon PG, Mangan NE. Suppression of TH2-type allergic reactions by helminth infection. Nature reviews. 2007 Mar;7(3):220-30.

137. Yazdanbakhsh M, Kremsner PG, van Ree R. Allergy, parasites, and the hygiene hypothesis. Science (New York, NY. 2002 Apr 19;296(5567):490-4.

138. Cookson W. The immunogenetics of asthma and eczema: a new focus on the epithelium. Nature reviews. 2004 Dec;4(12):978-88.

139. Barker DJ. The origins of the developmental origins theory. Journal of internal medicine. 2007 May;261(5):412-7.

140. Barker DJ. The developmental origins of adult disease. J Am Coll Nutr. 2004 Dec;23(6 Suppl):588S-95S.

141. Gluckman PD, Hanson MA, Beedle AS. Early life events and their consequences for later disease: a life history and evolutionary perspective. Am J Hum Biol. 2007 Jan-Feb;19(1):1-19. 
142. St Clair D, Xu M, Wang P, Yu Y, Fang Y, Zhang F, et al. Rates of adult schizophrenia following prenatal exposure to the Chinese famine of 1959-1961. JAMA. 2005 Aug 3;294(5):557-62.

143. van Os J, Selten JP. Prenatal exposure to maternal stress and subsequent schizophrenia. The May 1940 invasion of The Netherlands. Br J Psychiatry. 1998 Apr;172:324-6.

144. Jirtle RL, Skinner MK. Environmental epigenomics and disease susceptibility. Nature reviews. 2007 Apr;8(4):253-62.

145. Wolff GL, Kodell RL, Moore SR, Cooney CA. Maternal epigenetics and methyl supplements affect agouti gene expression in Avy/a mice. FASEB J. 1998 Aug;12(11):949-57.

146. Waterland RA, Jirtle RL. Transposable elements: targets for early nutritional effects on epigenetic gene regulation. Molecular and cellular biology. 2003 Aug;23(15):5293-300.

147. Ho SM, Tang WY, Belmonte de Frausto J, Prins GS. Developmental exposure to estradiol and bisphenol A increases susceptibility to prostate carcinogenesis and epigenetically regulates phosphodiesterase type 4 variant 4. Cancer research. 2006 Jun 1;66(11):5624-32.

148. Weaver IC, Champagne FA, Brown SE, Dymov S, Sharma S, Meaney MJ, et al. Reversal of maternal programming of stress responses in adult offspring through methyl supplementation: altering epigenetic marking later in life. J Neurosci. 2005 Nov 23;25(47):11045-54.

149. Koturbash I, Baker M, Loree J, Kutanzi K, Hudson D, Pogribny I, et al. Epigenetic dysregulation underlies radiation-induced transgenerational genome instability in vivo. Int J Radiat Oncol Biol Phys. 2006 Oct 1;66(2):327-30.

150. Breton CV, Byun HM, Wenten M, Pan F, Yang A, Gilliland FD. Prenatal tobacco smoke exposure affects global and gene-specific DNA methylation. American journal of respiratory and critical care medicine. 2009 Sep 1;180(5):462-7.

151. van Panhuys N, Le Gros G, McConnell MJ. Epigenetic regulation of Th2 cytokine expression in atopic diseases. Tissue Antigens. 2008 Aug;72(2):91-7.

152. Sanders VM. Epigenetic regulation of Th1 and Th2 cell development. Brain, behavior, and immunity. 2006 Jul;20(4):317-24.

153. Zhu J, Min B, Hu-Li J, Watson CJ, Grinberg A, Wang Q, et al. Conditional deletion of Gata3 shows its essential function in T(H)1-T(H)2 responses. Nature immunology. 2004 Nov;5(11):115765.

154. Lin JX, Leonard WJ. The role of Stat5a and Stat5b in signaling by IL-2 family cytokines. Oncogene. 2000 May 15;19(21):2566-76.

155. Moriggl R, Topham DJ, Teglund S, Sexl V, McKay C, Wang D, et al. Stat5 is required for IL-2induced cell cycle progression of peripheral T cells. Immunity. 1999 Feb;10(2):249-59.

156. Yamashita M, Ukai-Tadenuma M, Kimura M, Omori M, Inami M, Taniguchi M, et al. Identification of a conserved GATA3 response element upstream proximal from the interleukin-13 gene locus. The Journal of biological chemistry. 2002 Nov 1;277(44):42399-408.

157. Loots GG, Locksley RM, Blankespoor CM, Wang ZE, Miller W, Rubin EM, et al. Identification of a coordinate regulator of interleukins 4, 13, and 5 by cross-species sequence comparisons. Science (New York, NY. 2000 Apr 7;288(5463):136-40.

158. Solymar DC, Agarwal S, Bassing CH, Alt FW, Rao A. A 3' enhancer in the IL-4 gene regulates cytokine production by Th2 cells and mast cells. Immunity. 2002 Jul;17(1):41-50.

159. Ansel KM, Greenwald RJ, Agarwal S, Bassing CH, Monticelli S, Interlandi J, et al. Deletion of a conserved Il4 silencer impairs T helper type 1-mediated immunity. Nature immunology. 2004 Dec;5(12):1251-9.

160. Lee GR, Spilianakis CG, Flavell RA. Hypersensitive site 7 of the TH2 locus control region is essential for expressing TH2 cytokine genes and for long-range intrachromosomal interactions. Nature immunology. 2005 Jan;6(1):42-8. 
161. Bird JJ, Brown DR, Mullen AC, Moskowitz NH, Mahowald MA, Sider JR, et al. Helper T cell differentiation is controlled by the cell cycle. Immunity. 1998 Aug;9(2):229-37.

162. Seki N, Miyazaki M, Suzuki W, Hayashi K, Arima K, Myburgh E, et al. IL-4-induced GATA-3 expression is a time-restricted instruction switch for Th2 cell differentiation. J Immunol. 2004 May 15;172(10):6158-66.

163. Lee HJ, Takemoto N, Kurata H, Kamogawa Y, Miyatake S, O'Garra A, et al. GATA-3 induces T helper cell type 2 (Th2) cytokine expression and chromatin remodeling in committed Th1 cells. The Journal of experimental medicine. 2000 Jul 3;192(1):105-15.

164. Yamashita M, Hirahara K, Shinnakasu R, Hosokawa H, Norikane S, Kimura MY, et al. Crucial role of MLL for the maintenance of memory $\mathrm{T}$ helper type 2 cell responses. Immunity. 2006 May;24(5):611-22.

165. Koyanagi M, Baguet A, Martens J, Margueron R, Jenuwein T, Bix M. EZH2 and histone 3 trimethyl lysine 27 associated with Il4 and Il13 gene silencing in Th1 cells. The Journal of biological chemistry. 2005 Sep 9;280(36):31470-7.

166. Miller RL, Ho SM. Environmental epigenetics and asthma: current concepts and call for studies. American journal of respiratory and critical care medicine. 2008 Mar 15;177(6):567-73.

167. Hatchwell E, Greally JM. The potential role of epigenomic dysregulation in complex human disease. Trends Genet. 2007 Nov;23(11):588-95.

168. Ptak C, Petronis A. Epigenetics and complex disease: from etiology to new therapeutics. Annual review of pharmacology and toxicology. 2008;48:257-76.

169. Richards EJ. Inherited epigenetic variation--revisiting soft inheritance. Nature reviews. 2006 May;7(5):395-401.

170. Survey NF. Household consumption of selected foods from 1942 onwards. 2001; Available from: http://statistics.defra.gov.uk/esg/publications/nfs/datasets/allfoods.xls.

171. Hollingsworth JW, Maruoka S, Boon K, Garantziotis S, Li Z, Tomfohr J, et al. In utero supplementation with methyl donors enhances allergic airway disease in mice. The Journal of clinical investigation. 2008 Oct;118(10):3462-9.

172. Rosenquist TH, Finnell RH. Genes, folate and homocysteine in embryonic development. The Proceedings of the Nutrition Society. 2001 Feb;60(1):53-61.

173. Feinberg AP, Tycko B. The history of cancer epigenetics. Nat Rev Cancer. 2004 Feb;4(2):143-53.

174. Perera F, Tang WY, Herbstman J, Tang D, Levin L, Miller R, et al. Relation of DNA methylation of 5'-CpG island of ACSL3 to transplacental exposure to airborne polycyclic aromatic hydrocarbons and childhood asthma. PLoS ONE. 2009;4(2):e4488.

175. Miller RL, Garfinkel R, Horton M, Camann D, Perera FP, Whyatt RM, et al. Polycyclic aromatic hydrocarbons, environmental tobacco smoke, and respiratory symptoms in an inner-city birth cohort. Chest. 2004 Oct;126(4):1071-8.

176. Wu M, Ho SM. PMP24, a gene identified by MSRF, undergoes DNA hypermethylationassociated gene silencing during cancer progression in an LNCaP model. Oncogene. 2004 Jan 8;23(1):250-9.

177. Braun-Fahrlander C, Lauener R. Farming and protective agents against allergy and asthma. Clin Exp Allergy. 2003 Apr;33(4):409-11.

178. von Mutius E, Braun-Fahrlander C, Schierl R, Riedler J, Ehlermann S, Maisch S, et al. Exposure to endotoxin or other bacterial components might protect against the development of atopy. Clin Exp Allergy. 2000 Sep;30(9):1230-4. 
179. Schaub B, Liu J, Hoppler S, Schleich I, Huehn J, Olek S, et al. Maternal farm exposure modulates neonatal immune mechanisms through regulatory $\mathrm{T}$ cells. The Journal of allergy and clinical immunology. 2009 Apr;123(4):774-82 e5.

180. Saetta M, Turato G, Maestrelli P, Mapp CE, Fabbri LM. Cellular and structural bases of chronic obstructive pulmonary disease. American journal of respiratory and critical care medicine. 2001 May;163(6):1304-9.

181. Barnes PJ, Shapiro SD, Pauwels RA. Chronic obstructive pulmonary disease: molecular and cellular mechanisms. Eur Respir J. 2003 Oct;22(4):672-88.

182. Yang SR, Chida AS, Bauter MR, Shafiq N, Seweryniak K, Maggirwar SB, et al. Cigarette smoke induces proinflammatory cytokine release by activation of NF-kappaB and posttranslational modifications of histone deacetylase in macrophages. American journal of physiology. 2006 Jul;291(1):L46-57.

183. Marwick JA, Kirkham PA, Stevenson CS, Danahay H, Giddings J, Butler K, et al. Cigarette smoke alters chromatin remodeling and induces proinflammatory genes in rat lungs. American journal of respiratory cell and molecular biology. 2004 Dec;31(6):633-42.

184. Lovik M, Hogseth AK, Gaarder PI, Hagemann R, Eide I. Diesel exhaust particles and carbon black have adjuvant activity on the local lymph node response and systemic IgE production to ovalbumin. Toxicology. 1997 Aug 15;121(2):165-78.

185. Moerloose KB, Robays LJ, Maes T, Brusselle GG, Tournoy KG, Joos GF. Cigarette smoke exposure facilitates allergic sensitization in mice. Respiratory research. 2006; 7:49.

186. Digel W, Lubbert M. DNA methylation disturbances as novel therapeutic target in lung cancer: preclinical and clinical results. Critical reviews in oncology/hematology. 2005 Jul;55(1):111.

187. Ober C, Thompson EE. Rethinking genetic models of asthma: the role of environmental modifiers. Current opinion in immunology. 2005 Dec;17(6):670-8.

188. Li YF, Langholz B, Salam MT, Gilliland FD. Maternal and grandmaternal smoking patterns are associated with early childhood asthma. Chest. 2005 Apr;127(4):1232-41.

189. Standards for the diagnosis and care of patients with chronic obstructive pulmonary disease. American Thoracic Society. American journal of respiratory and critical care medicine. 1995 Nov;152(5 Pt 2):S77-121.

190. Bindslev-Jensen C, Poulsen LK. Accuracy of in vivo and in vitro tests. Allergy. 1998;53(46 Suppl):72-4.

191. Zhao H, Hastie T, Whitfield ML, Borresen-Dale AL, Jeffrey SS. Optimization and evaluation of T7 based RNA linear amplification protocols for cDNA microarray analysis. BMC genomics. 2002 Oct 30;3(1):31.

192. Livak KJ, Schmittgen TD. Analysis of relative gene expression data using real-time quantitative PCR and the 2(-Delta Delta C(T)) Method. Methods. 2001 Dec;25(4):402-8.

193. Oda M, Glass JL, Thompson RF, Mo Y, Olivier EN, Figueroa ME, et al. High-resolution genome-wide cytosine methylation profiling with simultaneous copy number analysis and optimization for limited cell numbers. Nucleic acids research. 2009 Jul;37(12):3829-39.

194. Singer J, Roberts-Ems J, Riggs AD. Methylation of mouse liver DNA studied by means of the restriction enzymes msp I and hpa II. Science (New York, NY. 1979 Mar 9;203(4384):1019-21.

195. Thompson RF, Reimers M, Khulan B, Gissot M, Richmond TA, Chen Q, et al. An analytical pipeline for genomic representations used for cytosine methylation studies. Bioinformatics (Oxford, England). 2008 May 1;24(9):1161-7.

196. Team RDC. R: A Language and Environment for Statistical Computing. R Foundation for Statistical Computing, Vienna, Austria. 2005. 
197. Grunau C, Clark SJ, Rosenthal A. Bisulfite genomic sequencing: systematic investigation of critical experimental parameters. Nucleic acids research. 2001 Jul 1;29(13):E65-5.

198. Li LC, Dahiya R. MethPrimer: designing primers for methylation PCRs. Bioinformatics (Oxford, England). 2002 Nov;18(11):1427-31.

199. Aranyi T, Varadi A, Simon I, Tusnady GE. The BiSearch web server. BMC bioinformatics. 2006;7:431.

200. Tusnady GE, Simon I, Varadi A, Aranyi T. BiSearch: primer-design and search tool for PCR on bisulfite-treated genomes. Nucleic acids research. 2005;33(1):e9.

201. Bird AP. DNA methylation and the frequency of CpG in animal DNA. Nucleic acids research. 1980 Apr 11;8(7):1499-504.

202. Bestor TH, Hellewell SB, Ingram VM. Differentiation of two mouse cell lines is associated with hypomethylation of their genomes. Molecular and cellular biology. 1984 Sep;4(9):1800-6.

203. Kent WJ, Sugnet CW, Furey TS, Roskin KM, Pringle TH, Zahler AM, et al. The human genome browser at UCSC. Genome research. 2002 Jun;12(6):996-1006.

204. Sharma S, Kelly TK, Jones PA. Epigenetics in cancer. Carcinogenesis. 2010 Jan;31(1):27-36.

205. Thompson RF, Einstein FH. Epigenetic Basis for Fetal Origins of Age-Related Disease. J Womens Health (Larchmt). 2010 Feb 7.

206. Einstein F, Thompson RF, Bhagat TD, Fazzari MJ, Verma A, Barzilai N, et al. Cytosine methylation dysregulation in neonates following intrauterine growth restriction. PLoS ONE. 2010;5(1):e8887.

207. Martino DJ, Prescott SL. Silent mysteries: epigenetic paradigms could hold the key to conquering the epidemic of allergy and immune disease. Allergy. 2010 Jan;65(1):7-15.

208. Prescott SL, Clifton V. Asthma and pregnancy: emerging evidence of epigenetic interactions in utero. Current opinion in allergy and clinical immunology. 2009 0ct;9(5):417-26.

209. Urdinguio RG, Sanchez-Mut JV, Esteller M. Epigenetic mechanisms in neurological diseases: genes, syndromes, and therapies. Lancet Neurol. 2009 Nov;8(11):1056-72.

210. Freeman DJ. Effects of maternal obesity on fetal growth and body composition: implications for programming and future health. Semin Fetal Neonatal Med. 2009 Oct 21.

211. Langley-Evans SC, McMullen S. Developmental origins of adult disease. Med Princ Pract. 2010;19(2):87-98.

212. Parronchi P, De Carli M, Manetti R, Simonelli C, Sampognaro S, Piccinni MP, et al. IL-4 and IFN (alpha and gamma) exert opposite regulatory effects on the development of cytolytic potential by Th1 or Th2 human T cell clones. J Immunol. 1992 Nov 1;149(9):2977-83.

213. Larosa DF, Orange JS. 1. Lymphocytes. The Journal of allergy and clinical immunology. 2008 Feb;121(2 Suppl):S364-9; quiz S412.

214. Sanz I, Wei C, Lee FE, Anolik J. Phenotypic and functional heterogeneity of human memory B cells. Semin Immunol. 2008 Feb;20(1):67-82.

215. Figueroa ME, Lugthart S, Li Y, Erpelinck-Verschueren C, Deng X, Christos PJ, et al. DNA methylation signatures identify biologically distinct subtypes in acute myeloid leukemia. Cancer Cell. 2010 Jan 19;17(1):13-27.

216. Diede SJ, Guenthoer J, Geng LN, Mahoney SE, Marotta M, Olson JM, et al. DNA methylation of developmental genes in pediatric medulloblastomas identified by denaturation analysis of methylation differences. Proceedings of the National Academy of Sciences of the United States of America. 2010 Jan 5;107(1):234-9.

217. Hamilton JA. Colony-stimulating factors in inflammation and autoimmunity. Nature reviews. 2008 Jul;8(7):533-44. 
218. Chitu V, Stanley ER. Colony-stimulating factor-1 in immunity and inflammation. Current opinion in immunology. 2006 Feb;18(1):39-48.

219. Bozinovski S, Jones J, Beavitt SJ, Cook AD, Hamilton JA, Anderson GP. Innate immune responses to LPS in mouse lung are suppressed and reversed by neutralization of GM-CSF via repression of TLR-4. American journal of physiology. 2004 Apr;286(4):L877-85.

220. Bozinovski S, Jones JE, Vlahos R, Hamilton JA, Anderson GP. Granulocyte/macrophagecolony-stimulating factor (GM-CSF) regulates lung innate immunity to lipopolysaccharide through Akt/Erk activation of NFkappa B and AP-1 in vivo. The Journal of biological chemistry. 2002 Nov 8;277(45):42808-14.

221. Georas SN, Guo J, De Fanis U, Casolaro V. T-helper cell type-2 regulation in allergic disease. Eur Respir J. 2005 Dec;26(6):1119-37.

222. Yamane H, Zhu J, Paul WE. Independent roles for IL-2 and GATA-3 in stimulating naive CD4+ $\mathrm{T}$ cells to generate a Th2-inducing cytokine environment. The Journal of experimental medicine. 2005 Sep 19;202(6):793-804.

223. Zhu J, Paul WE. CD4 T cells: fates, functions, and faults. Blood. 2008 Sep 1;112(5):1557-69.

224. Yoshimoto T, Paul WE. CD4pos, NK1.1pos T cells promptly produce interleukin 4 in response to in vivo challenge with anti-CD3. The Journal of experimental medicine. 1994 Apr 1;179(4):1285-95.

225. Yoshimoto T, Yasuda K, Tanaka H, Nakahira M, Imai Y, Fujimori Y, et al. Basophils contribute to $\mathrm{T}(\mathrm{H}) 2-\mathrm{IgE}$ responses in vivo via IL-4 production and presentation of peptide-MHC class II complexes to CD4+ T cells. Nature immunology. 2009 Jul;10(7):706-12.

226. Paul WE, Zhu J. How are T(H)2-type immune responses initiated and amplified? Nature reviews. 2010 Apr;10(4):225-35.

227. Batista FD, Harwood NE. The who, how and where of antigen presentation to B cells. Nature reviews. 2009 Jan;9(1):15-27.

228. Holick MF. Vitamin D deficiency. The New England journal of medicine. 2007 Jul 19;357(3):266-81.

229. Song Y, Qi H, Wu C. Effect of 1,25-(OH)2D3 (a vitamin D analogue) on passively sensitized human airway smooth muscle cells. Respirology. 2007 Jul;12(4):486-94.

230. Hughes DA, Norton R. Vitamin D and respiratory health. Clin Exp Immunol. 2009 Oct;158(1):20-5.

231. Devereux G, Litonjua AA, Turner SW, Craig LC, McNeill G, Martindale S, et al. Maternal vitamin $D$ intake during pregnancy and early childhood wheezing. The American journal of clinical nutrition. 2007 Mar;85(3):853-9.

232. Camargo CA, Jr., Rifas-Shiman SL, Litonjua AA, Rich-Edwards JW, Weiss ST, Gold DR, et al. Maternal intake of vitamin D during pregnancy and risk of recurrent wheeze in children at $3 \mathrm{y}$ of age. The American journal of clinical nutrition. 2007 Mar;85(3):788-95.

233. Gupta RA, Shah N, Wang KC, Kim J, Horlings HM, Wong DJ, et al. Long non-coding RNA HOTAIR reprograms chromatin state to promote cancer metastasis. Nature. 2010 Apr 15;464(7291):1071-6.

234. Hernandez-Vargas H, Lambert MP, Le Calvez-Kelm F, Gouysse G, McKay-Chopin S, Tavtigian SV, et al. Hepatocellular carcinoma displays distinct DNA methylation signatures with potential as clinical predictors. PLoS ONE. 2010;5(3):e9749.

235. Heijmans BT, Tobi EW, Stein AD, Putter H, Blauw GJ, Susser ES, et al. Persistent epigenetic differences associated with prenatal exposure to famine in humans. Proceedings of the National Academy of Sciences of the United States of America. 2008 Nov 4;105(44):17046-9. 
236. Duester G. Families of retinoid dehydrogenases regulating vitamin A function: production of visual pigment and retinoic acid. European journal of biochemistry / FEBS. 2000 Jul;267(14):4315-24.

237. Pino-Lagos K, Benson MJ, Noelle RJ. Retinoic acid in the immune system. Ann N Y Acad Sci. 2008 Nov;1143:170-87.

238. Blomhoff R, Blomhoff HK. Overview of retinoid metabolism and function. Journal of neurobiology. 2006 Jun;66(7):606-30.

239. Carman JA, Pond L, Nashold F, Wassom DL, Hayes CE. Immunity to Trichinella spiralis infection in vitamin A-deficient mice. The Journal of experimental medicine. 1992 Jan 1;175(1):111-20.

240. Cantorna MT, Nashold FE, Hayes CE. In vitamin A deficiency multiple mechanisms establish a regulatory $\mathrm{T}$ helper cell imbalance with excess Th1 and insufficient Th2 function. J Immunol. 1994 Feb 15;152(4):1515-22.

241. Ruhl R, Garcia A, Schweigert FJ, Worm M. Modulation of cytokine production by low and high retinoid diets in ovalbumin-sensitized mice. International journal for vitamin and nutrition research Internationale Zeitschrift fur Vitamin- und Ernahrungsforschung. 2004 Jul;74(4):279-84.

242. Wiedermann U, Hanson LA, Kahu H, Dahlgren UI. Aberrant T-cell function in vitro and impaired T-cell dependent antibody response in vivo in vitamin A-deficient rats. Immunology. 1993 Dec;80(4):581-6.

243. Iwata M, Eshima Y, Kagechika H. Retinoic acids exert direct effects on $\mathrm{T}$ cells to suppress Th1 development and enhance Th2 development via retinoic acid receptors. International immunology. 2003 Aug;15(8):1017-25.

244. Yu S, Xia M, Xu W, Chu Y, Wang Y, Xiong S. All-trans retinoic acid biases immune response induced by DNA vaccine in a Th2 direction. Vaccine. 2005 Oct 25;23(44):5160-7.

245. Stephensen CB, Jiang X, Freytag T. Vitamin A deficiency increases the in vivo development of IL-10-positive Th2 cells and decreases development of Th1 cells in mice. The Journal of nutrition. 2004 Oct;134(10):2660-6.

246. Engedal N, Ertesvag A, Blomhoff HK. Survival of activated human T lymphocytes is promoted by retinoic acid via induction of IL-2. International immunology. 2004 Mar;16(3):44353.

247. Smith SM, Hayes CE. Contrasting impairments in IgM and IgG responses of vitamin Adeficient mice. Proceedings of the National Academy of Sciences of the United States of America. 1987 Aug;84(16):5878-82.

248. Semba RD, Muhilal, Scott AL, Natadisastra G, Wirasasmita S, Mele L, et al. Depressed immune response to tetanus in children with vitamin A deficiency. The Journal of nutrition. 1992 Jan;122(1):101-7.

249. Pasatiempo AM, Bowman TA, Taylor CE, Ross AC. Vitamin A depletion and repletion: effects on antibody response to the capsular polysaccharide of Streptococcus pneumoniae, type III (SSS-III). The American journal of clinical nutrition. 1989 Mar;49(3):501-10.

250. Arora D, Ross AC. Antibody response against tetanus toxoid is enhanced by lipopolysaccharide or tumor necrosis factor-alpha in vitamin A-sufficient and deficient rats. The American journal of clinical nutrition. 1994 Apr;59(4):922-8.

251. Ross AC. Vitamin A deficiency and retinoid repletion regulate the antibody response to bacterial antigens and the maintenance of natural killer cells. Clinical immunology and immunopathology. 1996 Sep;80(3 Pt 2):S63-72.

252. Semba RD. Vitamin A and immunity to viral, bacterial and protozoan infections. The Proceedings of the Nutrition Society. 1999 Aug;58(3):719-27. 
253. Barclay AJ, Foster A, Sommer A. Vitamin A supplements and mortality related to measles: a randomised clinical trial. British medical journal (Clinical research ed. 1987 Jan 31;294(6567):2946.

254. Ogaro FO, Orinda VA, Onyango FE, Black RE. Effect of vitamin A on diarrhoeal and respiratory complications of measles. Tropical and geographical medicine. 1993;45(6):283-6.

255. Hussey GD, Klein M. A randomized, controlled trial of vitamin A in children with severe measles. The New England journal of medicine. 1990 Jul 19;323(3):160-4.

256. Ruhl R, Hanel A, Garcia AL, Dahten A, Herz U, Schweigert FJ, et al. Role of vitamin A elimination or supplementation diets during postnatal development on the allergic sensitisation in mice. Mol Nutr Food Res. 2007 Sep;51(9):1173-81.

257. Milner JD, Stein DM, McCarter R, Moon RY. Early infant multivitamin supplementation is associated with increased risk for food allergy and asthma. Pediatrics. 2004 Jul;114(1):27-32.

258. Kull I, Bergstrom A, Melen E, Lilja G, van Hage M, Pershagen G, et al. Early-life supplementation of vitamins $A$ and $D$, in water-soluble form or in peanut oil, and allergic diseases during childhood. The Journal of allergy and clinical immunology. 2006 Dec;118(6):1299-304.

259. Schuster GU, Kenyon NJ, Stephensen CB. Vitamin A deficiency decreases and high dietary vitamin A increases disease severity in the mouse model of asthma. J Immunol. 2008 Feb 1;180(3):1834-42.

260. Matheu V, Berggard K, Barrios Y, Arnau MR, Zubeldia JM, Baeza ML, et al. Impact on allergic immune response after treatment with vitamin A. Nutr Metab (Lond). 2009;6:44.

261. Pesonen M, Kallio MJ, Siimes MA, Ranki A. Retinol concentrations after birth are inversely associated with atopic manifestations in children and young adults. Clin Exp Allergy. 2007 Jan;37(1):54-61.

262. Al Senaidy AM. Serum vitamin A and beta-carotene levels in children with asthma. J Asthma. 2009 Sep;46(7):699-702.

263. Scheffel F, Heine G, Henz BM, Worm M. Retinoic acid inhibits CD40 plus IL-4 mediated IgE production through alterations of sCD23, sCD54 and IL-6 production. Inflamm Res. 2005 Mar;54(3):113-8.

264. Dilworth FJ, Chambon P. Nuclear receptors coordinate the activities of chromatin remodeling complexes and coactivators to facilitate initiation of transcription. Oncogene. 2001 May 28;20(24):3047-54.

265. Chambon P. A decade of molecular biology of retinoic acid receptors. Faseb J. 1996 Jul;10(9):940-54.

266. Balmer JE, Blomhoff R. Gene expression regulation by retinoic acid. J Lipid Res. 2002 Nov;43(11):1773-808.

267. Loudig O, Maclean GA, Dore NL, Luu L, Petkovich M. Transcriptional co-operativity between distant retinoic acid response elements in regulation of Cyp26A1 inducibility. The Biochemical journal. 2005 Nov 15;392(Pt 1):241-8.

268. Zhao D, McCaffery P, Ivins KJ, Neve RL, Hogan P, Chin WW, et al. Molecular identification of a major retinoic-acid-synthesizing enzyme, a retinaldehyde-specific dehydrogenase. European journal of biochemistry / FEBS. 1996 Aug 15;240(1):15-22.

269. Niederreither K, Fraulob V, Garnier JM, Chambon P, Dolle P. Differential expression of retinoic acid-synthesizing (RALDH) enzymes during fetal development and organ differentiation in the mouse. Mechanisms of development. 2002 Jan;110(1-2):165-71.

270. White JA, Guo YD, Baetz K, Beckett-Jones B, Bonasoro J, Hsu KE, et al. Identification of the retinoic acid-inducible all-trans-retinoic acid 4-hydroxylase. The Journal of biological chemistry. 1996 Nov 22;271(47):29922-7. 
271. Lee SJ, Perera L, Coulter SJ, Mohrenweiser HW, Jetten A, Goldstein JA. The discovery of new coding alleles of human CYP26A1 that are potentially defective in the metabolism of all-trans retinoic acid and their assessment in a recombinant cDNA expression system. Pharmacogenet Genomics. 2007 Mar;17(3):169-80.

272. Niederreither K, Subbarayan V, Dolle P, Chambon P. Embryonic retinoic acid synthesis is essential for early mouse post-implantation development. Nature genetics. 1999 Apr;21(4):444-8.

273. Sakai Y, Meno C, Fujii H, Nishino J, Shiratori H, Saijoh Y, et al. The retinoic acid-inactivating enzyme CYP26 is essential for establishing an uneven distribution of retinoic acid along the anterio-posterior axis within the mouse embryo. Genes \& development. 2001 Jan 15;15(2):213-25. 